\title{
International Photovoltaic Program Plan, Volume II: Appendices
}

Solar Energy Research Institute

Dennis Costello

Robert Koontz

David Posner

Patricia Heiferling

Jet Propulsion Laboratory

Paul Carpenter

Sylvia Foreman

Lewis Perelman
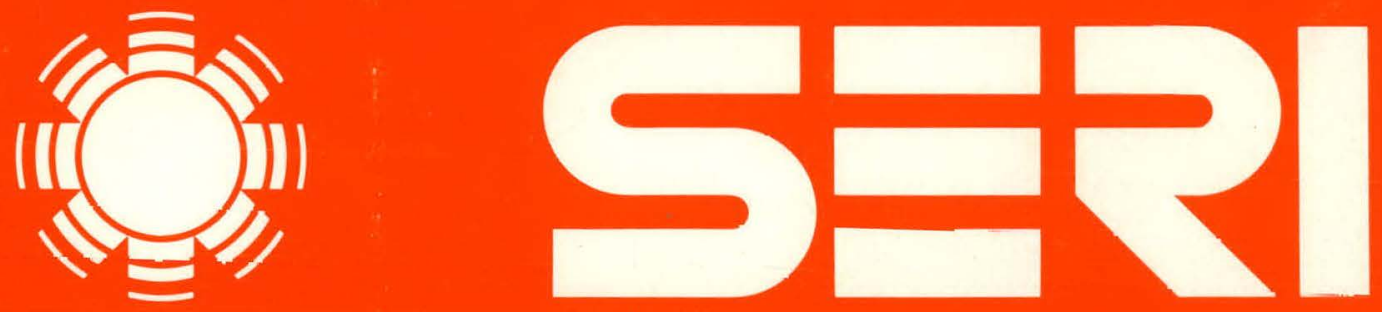

Solar Energy Research Institute A Division of Midwest Research Institute

1617 Cole Boulevard

Golden, Colorado 80401

Operated for the

U.S. Department of Energy

under Contract No. EG-77-C-01-4042 


\section{DISCLAIMER}

This report was prepared as an account of work sponsored by an agency of the United States Government. Neither the United States Government nor any agency Thereof, nor any of their employees, makes any warranty, express or implied, or assumes any legal liability or responsibility for the accuracy, completeness, or usefulness of any information, apparatus, product, or process disclosed, or represents that its use would not infringe privately owned rights. Reference herein to any specific commercial product, process, or service by trade name, trademark, manufacturer, or otherwise does not necessarily constitute or imply its endorsement, recommendation, or favoring by the United States Government or any agency thereof. The views and opinions of authors expressed herein do not necessarily state or reflect those of the United States Government or any agency thereof. 


\section{DISCLAIMER}

Portions of this document may be illegible in electronic image products. Images are produced from the best available original document. 
Printed in the United States of America

Available from:

Natinnal Technical Information Service

U.S. Department of Commerce

5285 Port Royal Road

Springfield, VA 22161

Price:

Microfiche $\$ 3.00 \mathrm{AO}$ l

Printed Copy $\$ 9.25 \mathrm{~A} 10$

\section{NOTICE}

This report was prepared as an account of work sponsored by the United States Government. Neither the United States nor the United States Department of Energy, nor any of their employees, nor any of their contractors, subcontractors, or their employees, makes any warranty, express or implied, or assumes any legal liability or responsibility for the accuracy, completeness or usefulness of any information, apparatus, product or process disclosed, or represents that its use would not infringe privately owned rights. 


\section{MASTER}

INTERNATIONAL PHOTOVOLTAIC.

PROGRAM PLAN, VOLUME II:

APPENDICES

DENNIS COSTELLO

ROBERT KOONTZ

DAVID POSNER

PATRICIA HEIFERLING

SOLAR ENERgY RESEARCH INSTI TUTE

PAUL CARPENTER

SYLVIA FORMAN.

LEW.IS PERELMAN

JET PROPULSION LABORATORY

Dé̇emBer 1979

PREPARED UNDER TASK NO. 5224

\section{Solar Energy Research Institute}

1536 Cole Boulevard

Golden, Colorado 80401

A Division of Midwest Research Institute

Prepared for the

U.S. Department of Energy

ContractNo. EG.77.C.01·4042

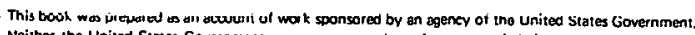
Neither the Unised Ststes Government nor any sgency thersol. nor any of their employees, makes nny warranty. express or implied. or assumes any legall liability of responsibility for the accuracy. completeness. of usatuness of any information, apparatus, product, or process disclosed. of

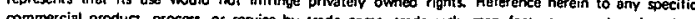



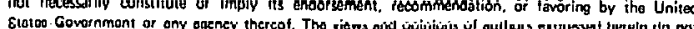

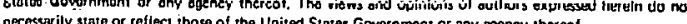




\section{THIS PACFF}

\section{WAS INTENTIONALLY}

LEFT BLANK 


\section{FOREWORD}

This second volume of a two-part report on the International Photovoltaic Program Plan (SERI Task No. 5224) contains appendices summarizing the results of analyses conducted in preparation of the plan. These analyses include compilations of relevant statutes and existing Federal programs; strategies designed to expand the use of photovoltaics abroad; information on the domestic photovoltaic plan and its impact on the proposed international plan; perspectives on foreign competition; industry views on the international photovoltaic market and ideas about how U.S. government actions could affect this market; international financing issues; and information on issues affecting foreign policy and developing countries.

The Solar Energy Research Institute (SERI), with support from the Jet Propulsion Laboratory (JPL), worked with several agencies to compile relevant statutory and program policy information (Appendix A). Drawing on this work and on other sources, the project team created a list of possible actions the Federal government could take to carry out the plan (Appendix B). SERI prepared an introduction to photovoltaic technology (Appendix C), and Tom Jaras, Science Applications, prepared a perspective on foreign competition in the photovoltaics market (Appendix D). SERI staff also compiled a section on industry perspectives (Appendix E). Under contract to JPL, an Illinois Institute of Technology Research Institute (IITRI) panel provided information on export techniques successful in similar situations (Appendix F). John Day and Robin Sacks, of Strategies Unlimited, provided a summary of their findings on international financial issues and institutions (Appendix G). Finally, JPL and the Massachusetts Institute of Technology (MIT) Energy Laboratory contributed papers on transnational issues and photovoltaic programs for developing countries.

Approved for:

SOLAR ENERGY RESEARCH INSTITUTE

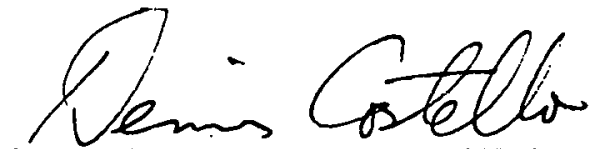

Dennis Costello, Branch Chief

Economic Analysis Branch 
is

THIS PAGE

\section{WAS INTENTIONALLY \\ LEFT BLANK}




\section{TABLE OF CONTENTS}

$\underline{\text { Page }}$

Appendix A Relevant Legislation and Programs ..................... I

Appendix B Programs and Government Actions Considered in

Preparing the Plan ............................. 27

Appendix C Introduction to Photovoltaic Technology .................. 37

Appendix D Characterization and Assessment of Potential European and

Japanese Competition in Photovoltaics (Summary) ............. 43

Appendix E Industry Perspectives on International Markets for

Photovoltaics ................................. 55

Appendix F Policy Strategies for the International Marketing of

U.S. Photovoltaics............................. 67

Appendix G Impact of International Financial Institutions on

Markets for Solar Energy Systems .................... 97

Appendix $\mathrm{H} \quad$ Photovoltaic Issues in Developing Countries................ 125

H.1 Summary: Photovoltaic International Plan Meeting ........ 127

H.2 Photovoltaics in the Third World $\ldots \ldots \ldots \ldots \ldots \ldots \ldots \ldots \ldots \ldots$

H.3 Photovoltaics in the Third World: Priorities of

Consuming Countries Concerning Commercialization........ 159

H.4 Transnational Issues of the International

Photovoltaic Program Plan .................... 197 
APPENDIX A

RELEVANT LEGISLATION AND PROGRAMS 
THIS PAGE

\section{WAS INTENTIONALLY \\ LEFT BLANK}




\section{APPENDIX A \\ RELEVANT LEGISLATION AND PROGRAMS}

\section{A.l RNTRODUCTION}

The Solar Energy Research, Development, and Demonstration Act of 1978 (PL 95-590) requires the Secretary of the U.S. Department of Energy (DOE), in consultation with the Secretary of State, the Administrator of the Agency for International Development (AID), the Director of ACTION, The Director of the Export/Import Bank, and other appropriate Federal officials to produce an international photovoltaic program plan. The legislation further requires that the plan be compatible, to the maximum extent possible, with other government agencies' activities, programs, and legislation.

To carry out this provision of the Act, representatives of DOE and other agency representatives, under the auspices of the International Solar Commercialization Working Group (ISCWG), met to discuss recommendations for implementation of the plan. Table A-l identifies the agencies and the individuals interviewed. In addition, the project team met with representatives of each agency to gather material on their activities, programs, and legislation. A working paper for each agency was prepared from the collected data and sent to each agency for reiteration and discussion.

This material, where applicable, is contained in the plan. For example, the principal photovoltaic projects for the Agency for International Development are listed in Section 1.0 of the plan. There are, however, legislation, activities, programs, and organizational characteristics of many of the agencies that are not detailed in the main program plan. Sec. A.2 of the appendix will review these characteristics, by agency.

\section{A.2 AGENCY ORGANIZATION, LEGISLATION, AND ACTIVITIES RELEVANT TO PHOTOVOLTAICS}

\section{A.2.1 Agency For International Development}

The Agency for International Development, (AID), an àgency within the U.S. Department of State, is charged with central direction and responsibility for the U.S foreign economic assistance program.

AID was authorized under the Foreign Assistance Act of 1961 (75 Stat. 424; 22 U.S.C. - 2381) and actually established by Executive Order 10973 (Nov. 3, 1961) and State Department Delegation of Authority No. 104 (Nov. 3, 1961; 26 FR 10603). In 1973 and 1975, Congressional legislation required that AID place its major emphasis on benefiting the poorest of the poor.

The general mission of the Agency for International Development is to "carry out assistance programs designed to help the people of certain less developed countries develop their human and economic resources, increase productive capacities, and improve the quality of human life as well as to promote economic or political stability in friendly countries."

Both the general mission of AID and the 1973 and 1975 legislation place constraints on how AID can participate in carrying out the objective of the International Photovoltaic 
Table A.1. AGENCIES AND INDIVIDUALS PARTICIPATING IN PROGRAM PLAN

\begin{tabular}{|c|c|}
\hline Agency & Individuals Interviewed \\
\hline Agency for International Development & $\begin{array}{l}\text { Jerome Bosken, William Anderson, } \\
\text { John Blumgart, Norman Brown, } \\
\text { Roger Moeller, Thomas O'Keefe, } \\
\text { Edgar Pike, Emmy Simmons }\end{array}$ \\
\hline U.S. Department of Commerce & . Nills Bassett, Larry Cozart \\
\hline U.S. Department of Defense & $\begin{array}{l}\text { William Sharky, Don Fain, } \\
\text { Ed Dyckman }\end{array}$ \\
\hline Export/Import Bank of the United States & $\begin{array}{l}\text { John Bicrman, } \\
\text { Frank Wilson }\end{array}$ \\
\hline Federal Trade Commission & Dennis Drabelle, Michael Straight \\
\hline $\begin{array}{l}\text { Institute for Scientific and } \\
\text { Technological Cooporation }\end{array}$ & $\begin{array}{l}\text { Princton Lyman, } \\
\text { William Jones }\end{array}$ \\
\hline U.S. Department of Justice & Glenn Stover \\
\hline $\begin{array}{l}\text { National Aeronautics and } \\
\text { Space Administration }\end{array}$ & $\begin{array}{l}\text { John Loria, } \\
\text { Larry Scudder }\end{array}$ \\
\hline $\begin{array}{l}\text { Office of the Special Representative } \\
\text { for Trade Negotiations }\end{array}$ & Steve Piper \\
\hline Overseas Private Investment Corporation & Rnhert Jordan \\
\hline Pcace Corps & Francis Luzzatto \\
\hline Small Business Administration & Tony Robinson \\
\hline U.S. Department of State & Marty Prochnik \\
\hline U.S. Department of the Treasury & Ted Rosen \\
\hline
\end{tabular}


Plan. Despite these constraints, there are important, if not crucial, roles AID can play. For example, AID now conducts photovoltaic demonstrations and will probably continue to do so in the future. In conducting these demonstrations, AID could assess their technical, economic, and political characteristics. This information, in turn, has important ramifications for user requirements and specifications, new applications, research design, and ultimately, future DOE photovoltaic development programs. Further, AID sponsored research and testing of a photovoltaic powered system with NASA-Lewis.

\section{A.2.1.1 Organization of the Ageney for International Development}

AID is headed by an Administrator who reports to the Secretary of State and to the President. The Agency is divided into two clusters of bureaus, geographic and functional. The geographic bureaus include Africa, Asia, Latin America and the Caribbean, and the Near East. The functional or problem-oriented bureaus include Development Support, Program and Policy Coordination, Intragovernmental and International Affairs, Private and Development Cooperation, and Program and Management Services.

\section{A.2.1.2 Energy-Related Organizations}

Within the Bureau for Development Support is a relatively new office, the Office of Energy. In addition to this office, each of the four geographic bureaus has a staff member designated as an advisor or coordinator for energy programs.

About 65 country missions have primary responsibility for generation and implementation of assistance programs and projects. The five nongeographic bureaus have limited responsibility and funding for program implementation. They operate primarily in policy formulation, budgetary allocation, funding basic research, and providing technical expertise for the country missions. On occasion, however, one of these bureaus-especially Development Support-may initiate projects. The current planning of a coordinated applications program to be conducted with NASA-Lewis by the AID Office of Energy is an example of central bureau programming.

\section{A.2.2 U.S. Department of Commerce}

The U.S. Department of Commerce (D́OC) encourages, serves, and promotes the nation's economic development and technological advancement.

DOC was designated as such by the Act of March.4, 1913, which reorganized the Department of Commerce and the Department of Labor into new, separate entities. The Act of February 14, 1903 (15 U.S.C. 1512 et seq.; 15 U.S.C. 171 et seq.) as amended, to foster, promote, and develop the foreign and domestic commerce of the United States; the Mutual Education and Cultural Exchange Act of 1961 (PS 87-256); and the Trade Promotion Authorization Act constitute DOC legislation. DOC comprises the Secretary and the operating units.

Figure A-1 gives a possible schema for DOC participation in the international photovoltaic plan. The information was furnished to the study team by DOC but does not represent an official endorsement. This schema did, however, furnish many ideas for plan actions. It also portrays DOC's special strengths. The ideas found in the schema are found throughout the plan. 
Proposed

International Photovoltaic Program. Plan

(under P.L. 95-590)

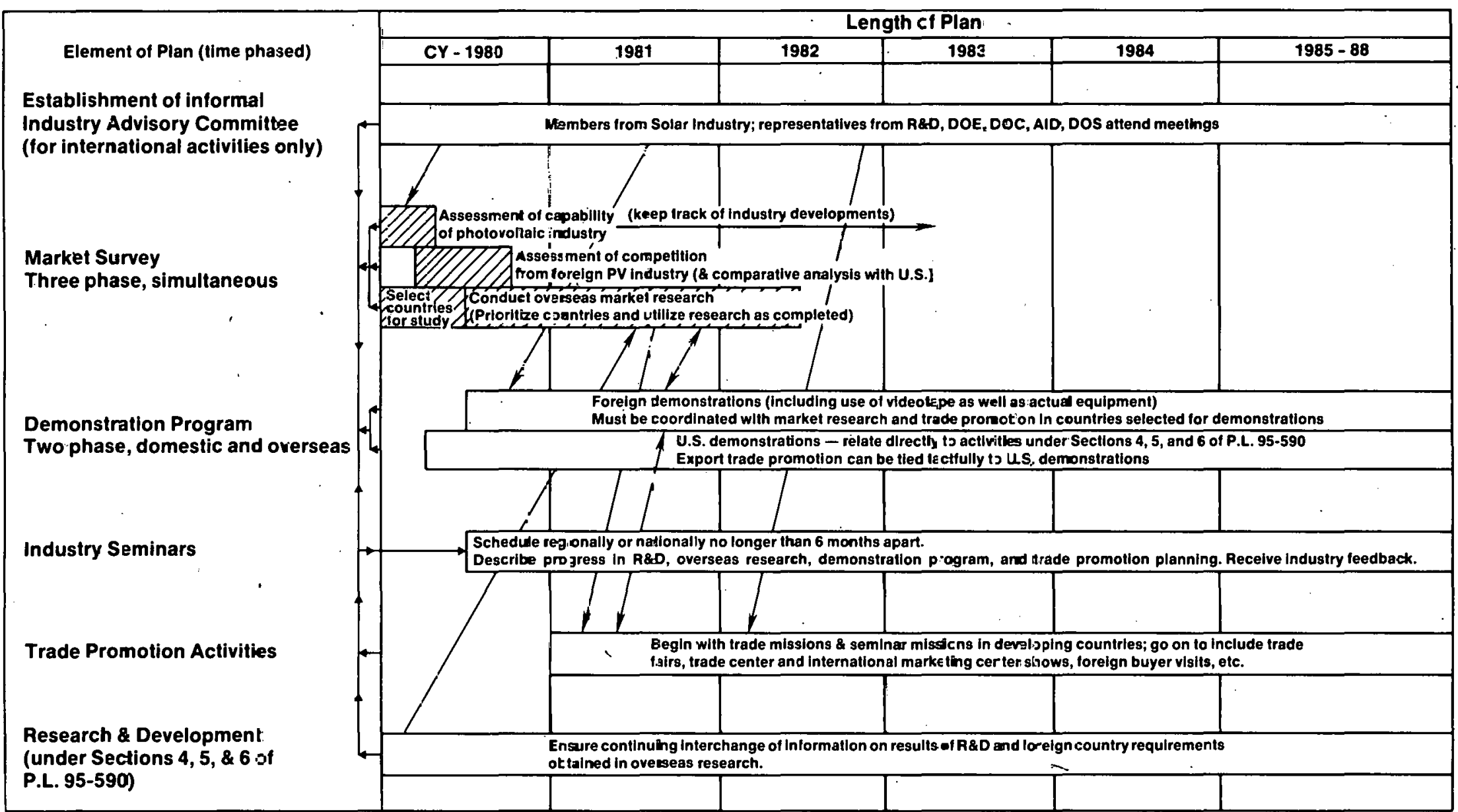

Figure A-1. SCHEMA OF PROPOSED INTERNATIONAL PHOTOVOLTAIC PROGRAM PLAN 


\section{A.2.2.1 Department of Commerce Administration and Bureaus}

DOC administration and bureaus that would participate in the plan are listed below, with a brief description of each one's responsibilities.

The Industry and Trade Administration (ITA) promotes growth of U.S. Foreign and domestic industry and commerce; foreign and domestic; stimulates the expansion of U.S. exports; and prepares and executes plans for industrial-mobilization readiness through government and business cooperation.

The Bureau of Export Development (BED) helps develop sales of U.S. business goods in the international market by providing commercial, economic, and marketing information on export prospects, methods for marketing goods, and information on prospective customers.

This bureau conducts export-development activities to increase national awareness of export opportunities; improves government business cooperation; and assists U.S. firms on specific major export projects. It manages export-promotion and export-expansion facilities, such as trade fairs and trade centers. In addition, it stimulates nonexporting U.S. businesses to participate in overseas markets, and it enlarges sales for present exporters. The bureau also coordinates the activities of the President's Export Council.

The Bureau of Field Operations (BPO). DOC maintains 43 District Offices, which bring the Department's services to the doorsteps of the nation's business community. Experienced trade specialists help U.S. companies penetrate foreign markets and expand domestic business as well. District Offices maintain an extensive business reference library containing periodicals, directories, publications, and reports from official as well as private sources. Most District Offices act as official sales agents of the Superintendent of Documents and stock Commerce and selected official government publications relating to business.

The Bureau of Domestic Business Development (BDBD) provides business assistance and advice to the nation's business community. It collects, analyzes, and maintains factual data on U.S. industries, including domestic and international data in categories such as production pricing, inventories, marketing, labor, financing, taxation, and location and size of companies. The BDBD provides a working for um for business and federal government on domestic-business issues. BDBD provides a focal point for receiving and handling complaints, suggestions, inquiries, and information on federal programs of interest to the business community, and it is responsible for consumer-affairs activities.

The Bureau of East-West Trade (BEWT) coordinates policies on trade promotion and other commercial relations with Socialist nations; performs economic analyses of problems peculiar to East-West trade; studies market potential for U.S. trade with Socialist nations; and provides analytic support for development of trade policy and the conduct of trade negotiations. BEWT manages export administration and related responsibilities under the Export Administration Act and the Equal Export Opportunity Act. The Bureau also provides executive secretariat services to U.S. joint commercial commissions with Socialist nations. 
The Bureau of Trade Regulation manages export administration and related activities under the Export Administration Act of 1969, as amended, including advice and assistance on regulating exports of U.S. goods and technology for purposes of national security, foreign policy, and short supply; developing and coordinating policies and measures concerning foreign boycotts against countries friendly to the United States; and conducting hearings with respect to administrative compliance and appeal proceedings.

This bureau performs national defense and industrial mobilization functions, provides secretariat and administrative support services to the Foreign-Trade Zone Board, and acts as assistant in several other programs.

The Bureau of International Economic Policy and Research (BIEPR) is responsible for coordinating activities involving the research, analysis, and formulation of international economic and commercial programs and pnlicies relating to trade, finance, und investinent as well as those of a bilateral, multilateral, or regional nature.

The bureau initiates and reviews research studies on devclopments affecting U.S. foreign trade and commercial interests abroad; provides the U.S. business community with statistical analytical, and economic information on foreign trade; and develops and implements the Department's position on trade and investment relations with individual countries and regional economic groupings. The Bureau represents the Department in international trade and related negotiations; and manages consultations with U.S. industry in support of multilateral trade negotiations. It develops and coordinates policy formulation and carries out the Department's interagency policy role.

The above-described Administration and bureaus within DOC would participate in the program within the bureaus' guidelines. Coordination and administration of DOC's participation be headed by the Industry and Trade Administration.

\section{A.2.2.2 Department of Commerce Services}

The following is a description of the various services available through DOC and those that will be useful in DOC program participation.

Global Marketing Program. As part of this program, DOC provides periodic repurts based on research studies in overseas markets with high growth potential. These reports, called Global Market Surveys (GMS), provide facts to help companies plan export marketing strategy. They highlight opportunities to promote U.S. products through Commercesponsored trade events.

U.S. Trade Centers. These are facilities for display, promotion, and sale of products. Trade centers are overseas commercial showrooms established in major marketing centers with potential for sales of U.S. products.

DOC and the U.S. Foreign Service, U.S. Department of State, operate a network of Trade Centers and East-West Trade Development Facilities, including a number in strategically located developing markets. Centers are located in Mexico City, Sao Paulo, Tokyo, and Taipei. The U.S. Commercial Office in Moscow and the Trade Development Center in Warsaw assist U.S. firms in several ways in doing business in nonmarket economies. 
U.S. International Marketing Centers. U.S. firms go where the customers traditionally gather-the recognized commercial fairs. Working out of the smaller International Marketing Centers (IMC), the staffs can stage U.S. Pavilions at international fairs in a number of countries in their respective geographic regions. In addition, small, specialized exhibitions can be accommodated at these permanent IMC facilities. Marketing centers are located in London, Milan, Paris, Singapore, and Sydney.

International Trade Fairs are a means of showing, demonstrating, and selling the product. More than $\mathbf{8 0 0}$ general and specialized international trade fairs are held each year.

Because the cost of exhibiting overseas on an individual basis usually prohibits this type of promotion by many firms, DOC sponsors an official U.S. participation in selected major international exhibitions. In areas where there are no suitable trade fairs, Commerce sponsors special solo exhibitions of American products. Exhibitions are scheduled only when in-depth research reveals excellent sales potential for products to be displayed.

A market promotion campaign is conducted prior to each exhibition by the trade center or international marketing center staff and the Embassy/Commercial section. The effort includes identification of all prospective customers, agents, and distributors in the marketing area, publicity in the selected media, and individual sales calls on the most promising sales prospects on behalf of each exhibitor.

The Foreign Buyers' Program is designed to encourage the maximum number of international buyers to visit the United States, and it will assist them in the purchase of U.S. goods and services while here. The State Department, through its diplomatic and consular posts and the overseas International Communications Agency, promote the program, which is divided into three parts:

1. Specialized Foreign Buyers' Group. Special buying groups visit the United States with itineraries developed to match business interests of various groups' members. Itineraries include prearranged plant visits and business appointments with selected suppliers.

2. U.S. Trade Shows. These shows must meet certain criteria; primarily, the products and services shown must have high sales potential in a large number of foreign markets. A DOC official welcomes visitors and arranges business discussions with U.S. exhibitors who are seeking international trade.

3. Individual Foreign Buyers' Program. This program assists foreign business executives visiting the United States by finding products or services of interest. Through Commerce district offices, trade associations and other cooperating agencies, U.S. suppliers are identified to match the business interests of potential foreign buyers. DOC assigns a Washington Project Officer as a contact for foreign business exccutives.

Agent/Distributor Service (ADS). ADS is used to locate foreign import agents and distributors. The essence of this service is the determination of a firm's interest in a specific export proposal and willingness to correspond with the U.S. requester. U.S. Foreign Service posts supply information on $1-6$ qualified representatives. The data consist of the names and addresses of foreign firms; names and titles of persons to contact; telephone 
numbers; cable addresses and telex numbers; and brief comments about the firms or their stated interest in the proposal(s).

Major Projects Program. This program is designed to help U.S. firms win contracts for planning, engineering, and constructing large foreign infrastructures and industrial systems projects, including equipment and turnkey installations. Assistance is provided by an American Embassy, a prospective foreign client, or a U.S. firm, when requested either to encourage U.S. companies to bid on a particular project or to help such companies pursue overseas contracts.

Speed and flexibility in developing a strategy for each case are essential elements of the assistance given to U.S. firms. As circumstances warrant, the Major Projects Division of the Office of Export Marketing Assistance mobilizes and coordinates appropriate support from other U.S. Government agencies, including foreign șervice posts abroad.

Trade Opportunities Program (TOP). Overseas trade opportunities, both private and government, are transmitted to the TOP computer through various American embassies and consulates. The U.S. business firms that subscribe to TOP indicate the product or products they wish to export; the type of opportunities desired (direct sales or representation); and countries of interest. The TOP computer matches the foreign buyers' product interests with the subscribers' interests. When a match occurs, a trade-opportunity notice is mailed to the subscriber.

Additional information, as well as subscription costs for the TOP Notice Service and the TOP Bulletin, can be obtained from Commerce district offices or the Trade Opportunities Program, Office of Export Marketing Assistance, Industry and Trade Administration, and DOC.

East-West Trade Assistance. ITA's Bureau of East-West Trade promotes and assists development of trade between the United States and Socialist countries, including the USSR, countries in Eastern Europe, and the People's Republic of China. It helps U.S. businesses explore Socialist markets; it offers information, advice, and assistance on various aspects of East-West Trade. It provides advice on business practices and assists with market development, marketing problems, and specific transactions. The bureau helps U.S. firms participate in trade fairs, exhibitions, and technical seminars to acquaint Socialist country officials with U.S. products.

Through its Trade Development Center in Warsaw and its U.S. Commercial Office in Moscow, the bureau provides many services, including market conditions, trade relations, and business opportunities. It assists in contacting appropriate purchasers and user's and helps find facilities for meetings, seminars, and temporary office space.

In addition, the bureau analyzes economic developments in Socialist countries to assess their market potential for U.S. products, and it provides specialized country-by-country assistance in interpreting the effects of current and planned economic developments in U.S. efforts to expand East-West trade. It also interprets and disseminates trade statistics on centrally planned economies and provides staff support and representation to the Joint Commercial Commissions established with the USSR, Poland, and Romania.

For information, the Deputy Assistant Secretary for East-West Trade, Department of Commerce, may be contacted. 
Commerce Action Groups for the Near Rast (CAGNE). The purpose of CAGNE is to assemble, analyze, and disseminate information for the U.S. business community on economic conditions and new opportunities in Algeria, Bahrain, Egypt, Iran, Iraq, Israel, Jordan, Kuwait, Lebanon, Libya, Morocco, Oman, People's Democratic Republic of Yemen, Qatar, Saudi Arabia, Syria, Tunisia, United Arab Emirates, and Yemen Arab Republic.

In addition to preparing marketing guides and surveys on individual countries, CAGNE plans and implements a trade-promotion program consisting of various types of events which, in most cases, provide personal contact between U.S. exporters and the Near East/North African customers. CAGNE helps U.S. companies gain a bigger share of major development, engineering, and construction projects by providing direct assistance from the first announcement of a project that is still in the planning stage to the actual contract award.

CAGNE serves as the focal point for Commerce participation in the joint commissions that have been formed with Egypt, Iran, Israel, Jordan, Saudi Arabia, and Tunisia. The commission mechanism enables CAGNE to bring U.S. technology and business expertise to bear on the economic development problems of various countries.

Information is available through DOC District Offices or the Commerce Action Group for the Near East, Industry Trade Administration.

Business Counseling Service. Personal counseling for exporters is available at DOC in Washington, D.C., or at any of DOC's 43 district offices. The Business Counseling Section of the Export Awareness Division offers guidance, in-depth counseling on the energy phase of international trade, and scheduling of appointments with appropriate officials within the Industry and Trade Administration, as well as with officials in other agencies. A wide range of information on major foreign projects under consideration by international financial institutions-World Bank Group, Inter-American Development Bank, Asian Development Bank, and the United Nations Development Programme-is available in the Business Counseling Section of the DOC building in Washington, D.C.

DOC's district offices also provide business counseling services; identify for eign markets for products or services; and suggest possible agents or distributors, sources of credit information, financing, insurance, and other special export assistance.

District Export Councils. In addition to the services offered by its district offices, DOC can furnish direct contact with business people experienced in all phases of export trade through its District Export Councils. Every city that has a district office has a District Export Council.

These councils assist in many workshops, seminars, and clinies on exporting that are arranged by the district offices in cooperation with chambers of commerce, trade associations, banks, trade schools, colleges, and the Small Business Administration. The councils also may arrange for private consultation between experienced and prospective exporters.

Comprising approximately 1,000 business and trade experts who serve without compensation, the councils can help Americans break into the export field. District Office directors can provide details of this program. 
Other Aids and Services. Other U.S. Government and private-source aids and services available are: Bureau of Census monthly, Foreign Trade Report, FT 140, U.S. Exports Commodity by Country. The Industry and Trade Administration publishes International Economic Indicators, Market Share Reports, and Index to Foreign Market Reports. Also available is the International Marketing Information Series.

\section{A.2.3 U.S. Department of Defense}

The U.S. Department of Defense (DOD) is the successor agency to the National Military Establishment created by the National Security Act of 1947 (61 Stat. 495). It was established as an executive department of the Government by the National Security Act Amendments of 1949 with the Secretary of Defense as its head (63 Stat. 578, 5 U.S.C. 101). Major amendments have been made to the act by Reorganization Plan 6 of 1953, effective June 30, 1953, and the Department of Defense Reorganization Act of 1958 (67 Stat. 638, 72 Stat. 514). The Act of October 21, 1977 (91 Stat. 1172), provided for the establishment of the two new positions of Under Secretary of Defense for Policy and Under Secretary of Defense for Research and Engincering.

DOD includes the Office of the Secretary of Defense and the Organization of the Joint Chiefs of Staff, the military departments and services within those departments, the unified and specified commands, and such other agencies as the Secretary of Defense establishes to meet specific requirements.

DOD has implemented an energy management program to achieve national energy goals and objectives mandated by Congress and the President to achieve greater energy selfsufficiency, reduce energy costs, and ensure operational readiness of the strategic and tactical forces. The Assistant Secretary of Defense for Manpower, Reserve Affairs, and Logistics (ASD(MRA\&L)) is the principal DOD energy official. The Deputy Assistant Secretary of Defense for Energy, Environment and Safety (DASD(EES)), reports to the ASD (MRA\&L) and has responsibility for developing overall DOD energy policy and is the focal point for all DOD energy matters. There are many agencies and military departments with responsibilities in this program. The organization for effective energy management in DOD is decentralized. It is structured flexibly to ensure adequate functional coordination.

The DOD energy management program covers three distinct but interrelated areas:

- energy supply to provide the energy for mobility operations and installations;

- energy conservation to reduce consumption in mobility fuels and utility energy sources that support installations;

- energy technology applications to better utilize more plentiful cnergy resourous and to demonstrate the feasibility of new energy technologies.

DOD has chartered a Defense Photovoltaic Program Office at the U.S. Army Mobility Equipment Research and Development Command. This office, located at Fort Belvoir, Virginia, is the DOD agency for terrestrial applications of solar energy. Thus fur, the office has demonstrated selected military applications, analyzed the potential DOD photovoltaic market, and established a tri-service coordinating mechanism on photovoltaic matters. Possible military applications for photovoltaics include battery charging, remote surveilalnce, communications, water purification, radar, and solar electric power plants. Many of these applications are currently in the demonstration phase. 
Those responsible for carrying out the international photovoltaic plan may want to keep abreast of DOD photovoltaic and energy activities.

\section{A.2.4 U.S. Department of Justice}

The U.S. Department of Justice (DOJ) was established by the act of June 22, 1870 (16 Stat. 162; 28 U.S.C. 501, 503), with the Attorney General as its head. Prior to 1870 the Attorney General was a member of the President's Cabinet but not the head of a department, since the office was created under authority of the act of September 24, 1789, as amended (1 Stat. 92, 16 Stat. 162; 28 U.S.C. 503).

The affairs and activities of the DOJ are generally directed by the Attorney General. There are many offices, divisions, bureaus, and boards under DOJ. The DOJ offices and divisions that may contribute some assistance in the plan are listed below with a brief description of each one's responsibilities.

The Assistant Attorney General in charge of the Office of Legal Counsel assists the Attorney General as legal adviser to the President and all executive branch agencies. The Office drafts legal opinions of the Attorney General rendered in response to requests from the President and heads of executive departments and provides written opinions and informal advice to requests from various agencies of the Government and the Presidential staff and advisers.

The Office acts as general counsel for the Department itself and outside counsel for the other agencies of the executive branch.

The Office coordinates the work of the Department with respect to treaties, executive agreements, and international organizations.

The Assistant Attorney General in charge of the Antitrust Division is responsible for enforcement of the Federal antitrust laws. The Antitrust Division investigates possible antitrust violations, conducts grand jury proceedings, prepares and tries antitrust cases, prosecutes appeals, and negotiates and enforces final judgments. Antitrust laws are enforced by criminal actions designed to punish violators for restraints on and monopolization of trade and by civil suits for injunctive relief aimed at maintaining or restoring competitive conditions in the system of free enterprise, which is protected by the antitrust laws.

The Division studies, reports, and advises on the competitive considerations involved in policies of government departments and agencies, and makes recommendations with respect to such policies. The Division is responsible for supporting competitive policies within the Federal Government through comment and testimony on pending legislation and other matters.

The Division represents the United States on the Restrictive Business Practices Committee and, through the Department of State, maintains liaison with foreign governments on antimonopoly laws and policies.

The Consumer Affairs Section of the Antitrust Division has primary responsibility for consumer protection activities. 


\section{A.2.5 U.S. Department of State}

The State Department's primary objective in the execution of our foreign policy is to promote the long-range security and well-being of the United States.

On January 10, 1781, the Department of Foreign Affairs was established. Congress did not allow the Department to take independent action. It was made the medium of all correspondence with our agents abroad. In 1789, the Department was reconstituted as the Department of State and its functions were so expanded as to make it the most important of the new executive offices. The State Department's authority has been further expanded in keeping with this nation's growing responsibilities in world affairs.

State Department bureaus and their activities are listed below. They include only those bureaus and activities that could relate to the International Photovoltaic Plan.

Oceans and International Environmental and Scientific Affairs (OIESA). The Bureau of OIESA has the responsibility for the formulation and implementation of pnlipips and proposals for the scientific and technological aspects of our relations with other countries and international organizations. It has management responsibility for a broad range of foreign policy issues and significant global problems related to oceans, fisheries, environment, population, nuclear technology, new energy technology, space and other fields of advanced technology, and for cooperative efforts dealing with the application and transfer of technology. The Bureau advises the Secretary where scientific and technological factors or the Bureau's functional responsibilities are concerned; represents the Department in international negotiations, where responsible; provides policy guidance to the U.S. oceanic, environmental, scientific, and technological communities on activities and programs affecting foreign policy issues; and assures effective coordination of policy responsibilities between the State Department and AID in the field of science and technology.

The Bureau develops and directs the carrying nut of policy recommendations relativc to U.S. participation in international science and technology programs and in bilateral cooperative programs related to its area of interest.

Intelligence and Research (I\&R). The Bureau of I\&R coordinates programs of intelligence, research, and analysis for the Department and for other Federal agencies, and produces intelligence studies and current intelligence analyses essential to foreign policy determination and execution. Through the office of External Research, it maintains lialson with cultural and educational institutions and other Federal agencies on matters relating to government contractual and private foreign affairs research.

Economic and Business Affairs. The Bureau of Economic and Business Affairs has overall responsibility for formulating and implementing policy regarding foreign economic matters, trade promotion, and business services of an international nature, and coordinating regional economic policy with other concerned bureaus.

Management. The Deputy Under Secretary for Management serves as the principal adviser to the Secretary and the Deputy Secretary on management matters, including control of organizational structure and assignments and functions within the Department, and the allocation of the Department's personnel and financial resources. It also directs and 
supervises the activities of the Director General of the Foreign Service, who is responsible for personnel policies and programs governing the Department and Foreign Service, and the Director of the Foreign Service Institute, who is responsible for specialized training and instruction programs.

Regional Bureaus. These comprise the Bureaus of African Affairs, European Affairs, East Asian and Pacific Affairs, Inter-American Affairs, and Near Eastern and South Asian Affairs. The Assistant Secretaries are responsible for advising the Secretary in the formulation of U.S. policies toward the countries within their regional jurisdiction and for guiding the operation of the U.S. diplomatic establishments in the countries in their geographic area. They direct, coordinate, and supervise interdepartmental and interagency matters. They are assisted in these duties by Directors within their bureaus, who are responsible for overall guidance and interdepartmental coordination with respect to their assigned countries. These Directors serve the needs of U.S. Ambassadors. They work closely with "country teams" at our missions abroad to insure that all elements of a mission in a given country jointly pursue U.S. foreign policy directives. The regional Assistant Secretaries also serve as Chairpersons of Interdepartmental Groups in the $\mathrm{Na-}$ tional Security Council system.

Foreign Service. Our representatives at 138 Embassies, 10 Missions, 66 Consulates General, 48 Consulates, 1 Special Office, 1 Branch Office, and 13 Consular Agencies throughout the world report to the State Department on the multitude of foreign developments bearing on the welfare and security of the American people. Ambassadors have full responsibility for implementing U.S. foreign policy by any and all U.S. Government personnel within their country of assignment, except the military. Their responsibilities include negotiating agreements between the United States and the host country, explaining and disseminating official U.S. policy, and maintaining cordial relations with the country's government and people.

\section{A.2.6 U.S. Department of Treasury}

The Department of Treasury or the Secretary of Treasury is responsible for formulating and recommending domestic and international financial policy and tax policy; participating in the formulation of broad fiscal policies that have general significance for the economy; and managing the public debt. The Secretary serves as Chairman of the Cabinetlevel Economic Policy Group and as U.S. Governor of the International Monetary Fund, the International Bank for Reconstruction and Development, the Inter-American Development Bank, the Asian Development Bank, and the African Development Fund.

Congress created the Treasury Department on September 2, 1789 (1 Stat. 65; 31 U.S.C. 1001). Subsequent acts have created the various bureaus and functions of the Department.

With the exception of the role played by Treasury in the Saudi Arabian-United States Joint Commission on Economic Cooperation, the Treasury Department has no programs or statutes that deal with photovoltaics. That is, international sales of photovoltaics are treated as any other technology for tax purposes or by other Treasury programs. The following list describes the Treasury programs that could relate to the International Plan for Photovoltaics, the Saudi Arabian-United States Joint Commission on Economic Cooperation, and possible actions llat Treasury might take to further the objective of the plan. 


\section{A.2.6.1 Relevant Treasury Programs}

There are two offices within Treasury that could become directly involved with photovoltaics: the Office of the Assistant Secretary (Tax Policy) and the Office of the Assistant Secretary (International Affairs). The Assistant Secretary (Tax Policy) analyzes tax policy, including proposed tax legislation and tax programs, and the effects of various tax measures. In addition, the Secretary provides legal advice and analysis on domestic and international tax matters; reviews international tax regulations and rulings; participates in international tax treaty regulations and in maintenance of relations with international organizations on tax matters and the preseription of depreciation rates and repair allowances.

The Office of the Assistant Secretary (International Affairs) advises and assists the Department in the formulation and execution of internationul financial, economic, monetary, commercial, energy, and trade policies and programs. This office conducts financial diplomacy with industrial and developing nations and regions; coordinates policies and programs of bilateral and multilateral development lending programs and institutions; formulates policy concerning financing of trade; and coordinates policies toward foreign investments in the United States and U.S. investments abroad. The office is also responsible for economic relations with Middle East countries. It supports the Secretary as Co-Chairman of the U.S.-Israel Joint Committee for Investment and Trade, and as a member of other Middle Eastern joint commissions.

\section{A.2.6.2 Saudi Arabian-United States Joint Commission on Economic Cooperation}

The Deputy for Saudi Arabian Affairs in Treasury has primary responsibility for U.S. involvement in the Joint Commission. The purpose of the Commission is to "promote programs of industrialization, trade, manpower training, agriculture, and science and technology." The Deputy for Saudi Arabian Affairs "... provides policy and operational guidance to U.S. action agencies, coordinates the development of projects, and monitors project progress."

U.S. action agencies include Agriculture; Commerce; Energy; Interior; Labor; Transportation; Health, Education, and Welfare; the General Services Administration; and the National Science Foundation.

Under the management of the Commission, the Department of Energy, in cooperation with the Saudi Arabian National Center for Science and Technology (SANCST), are pursuing a cooperative research program for development of solar energy. The five-year program totals $\$ 100$ million and is financed by matching funds from the two governments.

\section{A.3 EXPORT-IMPORT BANK OF THE UNITED STATES (EXIMBANK)}

Eximbank was authorized in 1934 as an agency of the United States by acts of Congress. Made an independent agency of the government by the Export-Import Bank Act of 1945, it was reincorpolated under Federal charter in 1947. The Export-Import Bank Act of 1945, as amended through November 10, 1978, (with specific reference to Sec. $(2)(b)(1)(C):$ "Consistent with the policy of section 501 of the Nuclear Non-Proliferation Act of 1978 and section 119 of the Foreign Assistance Act of 1961, the Board of Directors shall name an officer of the Bank whose duties shall include advising the President of the Bank on ways of promoting the export of goods and services to be used in the de- 
velopment, production, and distribution of non-nuclear renewable energy resources, disseminating information concerning export opportunities and the availability of Bank support for such activities, and acting as liaison between the Bank and the Department of Commerce and other appropriate departments and agencies." This Amendment would appear to give Eximbank authority to participate in the International Photovoltaic Plan, possibly through one or several of the programs listed that are now available or the initiation of a new specific program to aid the international marketing of photovoltaics.

\section{A.3.1 The Export-Import Bank Programs: Preliminary Commitments}

A preliminary commitment for a direct loan and/or a financial guarantee can be an important sales tool for American exporters. Eximbank will provide a U.S. supplier, the prospective borrower, or a participating financial institution with a Preliminary Commitment letter outlining the amount, terms, and conditions of the financial assistance it is prepared to extend to support major U.S. export sales.

To apply, a letter including all details of the proposed export transaction would be sent to the Office of the Secretary, Export/Import Bank. These are used to assist in financing multimillion dollar sales that call for repayment periods of five years or longer.

\section{A.3.2 Direct Loens}

In a major U.S. export transaction, Eximbank of ten extends a loan directly to the purchaser. This is also to assist in financing multimillion dollar sales that call for extended repayment periods of five years or longer.

The loan, in U.S. dollars, may support from $30 \%$ to $45 \%$ of the U.S. export value, but occasionally could go to $85 \%$. Interest rates usually range from $7-3 / 4 \%$ to $8-3 / 4 \%$ per annum, depending on the repayment period. A commitment fee of $1 / 2$ of $1 \%$ applies from authorization until disbursement.

The application for a direct loan is a letter that includes all details of the proposed transaction, documented evidence of the borrower's financial position, evidence that commercial sources cannot satisfactorily provide the required financing without Eximbank participation, description of foreign competition, and an analysis of the impact the sale is likely to have on equipment supplies and employment in the United States.

\section{A.3.3 Financial Guarantees}

Eximbank may provide a Financial Guarantee to commercial lenders for multimillion dollar exports to encourage commercial financing. The lender pays commitment and guarantee fees for this protection. A Financial Guarantee is usually issued in conjunction with a Dircet Loan from Eximbank. The two in combination may cover up to $85 \%$ of the export sale. A guarantee alone may cover up to $85 \%$ of a transaction, when there is no Eximbank Direct Loan.

The commercial lender applies to Eximbank for a Financial Guarantee by sending a letter including all known details of the proposed export transaction to the Office of the Secretary. 


\section{A.3.4 Private Export Funding Corporation (PEFCO)}

A privately owned corporation is prepared to finance, on a fixed-rate basis, portions of those major transactions in which the Export/Import Bank's Financial Guarantee exists, with maturities longer than those normally available from U.S. commercial banks.

Applications should be sent to PEFCO headquarters, 280 Park Ave., New York, New York 10017.

\section{A.3.5 Foreign Credit Insurance Association (PCIA)}

U:S. exporters who extend their own short-and medium-term credit to foreign customers may obtain commercial and political risk insurance from the FCIA, an association of private insurance companies working under a reinsurance and agency agreement with Exim.. bank. Applications should be sent to FCIA Headquarters, One World Trade Center, Ninth Floor, New York, New York 10048.

\section{A.3.6 Sorth-Term Comprehensive Policy (STCP)}

The Foreign Credit Insurance Program offers several policies intended to help businesses meet export requirements. STCP provides 180 days of commercial and political risk coverage and is regarded as the most useful insurance program for the small exporter.

\section{A.3.7 Small-Business Short-Term Comprehensive Insurance Policy (SBSTOIP)}

Eximbank and FCIA are offering a new short-term insurance policy specifically to meet the requirements of small business exporters. The policy is available to firms with a net worth of $\$ 2$ million or less and average annual export sales during the preceding two years of $\$ 350,000$ or less who have not previously used Eximbank or FCIA programs directly or indirectly. Special coverage will be provided for two years. Eximbank and FCIA w1ll cover 100 percent of the political risk and 95 percent of the commercial risk involved in the financed portion of the transaction. The policy frees the smaller exporter from the "first-loss" risk provisions found in the regular policies.

A Medium-Term Policy provides coverage for extended terms of 181 days to 5 years. Coverage of this term is usually required for sales of U.S. capital and quasi-capital equipment to foreign buyers. One of the chief differences between short-term and medium-term financing requirements is that on medium-term sales the foreign buyer must make a minimum down payment of 15 percent of contract value before credit risk coverage can be applied. The remaining risk is then spread among the exporter, the commercial bank, and Eximbank/FCIA; the latter takes the greatest portion.

The Combination Policy (short- and medium-term) affords protection to U.S. exporters who sell their goods through overseas dealers and distributors.

The Master Policy is structured to support exporters who may be shipping a variety of products to a number of different markets. It covers all (or a reasonable spread) of an exporter's eligible export sales, both short- and medium-term, made during a one-year period. It offers lower premiums, independent credit decisions by the exporters, and faster delivery of services to overseas buyers. 


\section{A.3.8 Other Eximbank Services}

\section{A.3.8.1 Commercial Bank Exporter Guarantees}

Eximbank provides medium-term guarantees to U.S. commercial banks that lend money to the foreign customers of U.S. exporters. The guarantee covers most of the commercial and political risks of nonpayment by the foreign buyer.

Application can be made through Eximbank's Exporter Credits and Guarantees Division.

The Commercial Bank Exporter Guarantee Program covers direct sale of U.S. capital and quasi-capital goods to foreign buyers. The Guarantee program is operated through a direct network of U.S. commercial banks. Over 280 national and regional banks participate in this program.

To use the program, the small exporter would apply to its bank for financing of overseas sales. The bank in turn would apply to Eximbank for guarantee coverage of the commercial and political risks involved in extending credit to designated overseas buyers.

\section{A.3.8.2 The Small Business Guarantee Program}

Eximbank will cover $100 \%$ of the political risk and $95 \%$ of the commercial risk involved in the financed portions for medium-term sales. The guarantees, which went into effect July 1, 1978, are offered to eligible small business exporters at the same rates as regular guarantee coverage to established exporters.

\section{A.3.8.3 Discount Loans}

Eximbank extends loans to U.S. commercial banks which provide export financing to encourage them to extend medium-term (one- to five-year repayment) export loans at fixed rates of interest. The commercial bank must obtain a commitment for a Discount Loan before shipment of the products. Banks should apply to Eximbank's Discount Section.

Eximbank will agree to buy eligible fixed-rate medium-term export debt obligations from U.S. commercial banks. With this assurance, Eximbank has given tangible support to banks - particularly the small ones - that offer fixed-rate loans in the medium-term area.

\section{A.3.8.4 Small Business Advisory Service (SBAS)}

To encourage smaller export firms, Eximbank maintains a Small Business Advisory Service to provide information on the availability and use of export credit insurance, guarantees, discount loans, and foreign bank credits supporting the sale of U.S. goods and services abroad. An Eximbank "Hotline" service has also been established to help small businesses. The toll-free telephone counseling service was designed to help answer questions that small business exporters may have concerning assistance in financing goods and services abroad. The toll-free number is (800) $424-5201$. 


\section{A.3.8.5 Optional Coverages}

Eximbank initiated a "Switch Cover Option" for its Medium-Term Insurance Bank Guarantee, Discount Loan, and CFF programs. This option was designed to assist U.S. exporters selling through distributors and dealers overseas. Under the option, eligible U.S. equipment that has been exported to a dealer under a floor-planning scheme could be insured, guaranteed, or financed under the name of the ultimate end user if the user is found to be creditworthy.

\section{A.4 FEDERAL TRADE COMMISSION}

The Federal Trade Commission (FTC) has statutory responsibility to enforce certain consumer protection laws and (with the Justice Department) certain antitrust laws, including the following:

(1) The Ferteral Trade Commission Act (15 U.S.C. $\$ 41$ et seq.), which prohibits "unfair methods of competition .... and unfair or deceptive acts or practices in or affecting commerce." The FTC Act has been interpretcd to authorize the FTC to prevent coinducl lliut violatés the Sherman Act (15 U.S.C. $\$ 1$ et seq.) (including monopolization, attempts to monopolize, and agreements in restraint of trade or commerce, such as agreements to fix prices, limit production, divide markets, allocate customers, engage in boycotts, or refrain from competing), the Clayton Act (15 U.S.C. $\$ 12$ et seq.) (including certain anticompetitive mergers and acquisitions, and certain tie-in, reciprocal, and exclusive dealing arrangements), and the Robinson-Patman Act (15 U.S.C. $\$ 13,13 a$ ) (including certain predatory pricing and predatory practices, as well as discrimination in price, service, rebates, etc., involving commodities sold for use, consumption, or resale within the United Státes).

(2) The Webb-Pomerene Act (15 U.S.C. $\$ 61$ et seq,), which permits FTC-approved export trade associations to conduct certain multicompany activities in other countries despite the fact that such activities might be illegal if ronducted within the United States. These activities conducted by Webb-Pomerene associations are lawful under U.S. law provided that:

(a) "(the) association, agreement, or act is not in restraint of trade within the United States, and is not in restraint of the export trade of any domestic competitor of such association"; and

(b) "(the) association does not, either in the.United States or elsewhere, enter into any agreement, under'stunding or conspiracy, or do any act which artificially or intentionally enhances or depresses prices within the United States of commodities of the cluss exported by such associations, or which substantially lessens oompctition within the Uniled States or otherwise restrains trade therein."

(3) The Fair Packaging and Labeling Act (15 U.S.C. $\$ 1451$ et seq.), which authorizes the FTC to prohibit unfair or deceptive packaging or labeling of certain commodities.

(4) The Magnuson-Moss Warranty Act (15 U.S.C. $\$ 2301$ et seq.), which authorizes the FTC to promulgate regulations on warranties and to promulgate trade practice rules. 
The FTC consists of five Commissioners. The FTC staff is divided into three bureaus (the Bureau of Competition, the Bureau of Consumer Protection, and the Bureau of Economics) and has an Office of Policy Planning.

\section{A.5 INSTTTUTE FOR SCIENTIFIC AND TECHNOLOGICAL COOPERATION}

The Institute for Scientific and Technological Cooperation (ISTC) fosters technological and scientific cooperation with and within developing countries; serves as the central research and new technology development agency within the U.S. development assistance community; and encourages sustained and focused attention by the scientific community on development problems. It is planned that AID will transfer some of its research programs to ISTC. It will develop its own research priorities and programs in close cooperation with specialists from both the U.S. and developing countries. Development of technologies to meet the energy needs of the rural poor is expected to be a high initial ISTC priority.

Working with developing country experts, ISTC plans to evaluate existing energy development projects; test the appropriateness of energy technologies to different social settings; analyze and assess alternative energy technologies; analyze and assess commercialization information; and exchange energy technology information both here and abroad.

\section{A.6 NATIONAL AERONAUTICS AND SPACE ADMINISTRATION}

The principal statutory functions of the National Aeronautics and Space Administration (NASA) are to conduct research for the solution of problems of flight within and outside the Earth's atmosphere; develop, construct, test, and operate aeronautical and space vehicles; conduct space exploration activities; arrange for the most effective utilization of the scientific and engineering resources of the United States with other nations for peaceful purposes; and provide for the widest practicable and appropriate dissemination of information concerning NASA's activities and their results.

NASA was established by the National Aeronautics and Space Act of 1958 (72 Stat. 426 U.S.C. 2451 et seq.), as amended. The Solar Photovoltaic Energy Research, Development, and Demonstration Act of 1978 (PL 95-590) indicates NASA participation in the program would be to assist in the research, development, and demonstration of solar photovoltaic energy technologies.

NASA is authorized to conduct programs in support of the nation's energy research and development needs. This authorization is contained in the Energy Reorganization Act of 1974, the Department of Energy (DOE) Organization Act of 1977, and the National Aeronautics and Space Administration Act of 1958, as amended. The DOE-NASA Memorandum of Understanding, dated March 21, 1978, describes the general conditions under which DOE-NASA cooperative efforts will be formulated and conducted.

\section{A.6.1 NASA Offices and Field Centers}

The following are NASA Headquarters, Offices, and Field Centers that may participate in the program with a brief description of each one's responsibilities.

- NASA Headquarters plans, coordinates, and has control of NASA programs, and hence oversees NASA photovoltaic programs. The NASA Administrator's office is located at Ileadquarters. 
- The five Program Offices conduct the planning, direction, and management of NASA's research and development programs. These offices report to and receive guidance from NASA's Administrator.

- The Office of Aeronautics and Space Technology is responsible for the conduct of programs to develop advanced technology to enable and enhance an aggressive pursuit of national objectives in aeronautics and space, to demonstrate this advanced technology, and to ensure its early utilization. Further, this office is charged to identify technology developed in the aeronautics and space programs that has potential for making major contributions to the solution of energy problems on Earth and to provide technical support to other agencies in developing specific applications, and to coordinate the application of NASA capabilities and facilities to programs of other agencies to accomplish energy-related research and development on a reimbursable basis. The Office coordinates the agency's total advanced research and technology program to assure its overall adequacy and to avoid duplication.

- The Energy Systems Division of the Office of Aeronautics and Space Technology plans, manages, and evaluates the NASA program activities that support the nativin's energy l'eseurch und development needs. 'I'his mission is accomplished through program activities in energy technology and energy systems or through the use of space technology. Energy technology relates NASA's capabilities to the $R \& D$ program needs of DOE and other governmental organizations and involves the terrestrial application of NASA engineering facilities and manpower. Energy systems involves the use of space's unique capabilities for assistance in solving energy problems. These program areas are managed and executed through the Solar Terrestrial Systems, Conservation and Fossil Energy Systems, and Space Utilization Offices, which reflect program content as defined in agreements with DOE and other agencies.

The Solar Terrestrial Systems Office is currently managing programs in solar heating and cooling, photovoltaics, solar thermal electric systems, wind turbine energy, and energy storage. It is also responsihle for program developmont and planning in biomass and O'TEC energy areas.

These offices direct appropriate technology identification and verification efforts to the application of NASA capabilities to energy needs. Proposals are prepared for consideration and reimbursed by DOE or other "user agencies." Each office is then responsible for implementation and management of the reimbursable project.

- Of NASA's 10 Field Centers and National Space Technology Laboratories, the tet. Propulsion Laboratory (JPL), Pasadena, California (operated under contract by the California Institute of 'Tellinoluyy), and the NASA-Lewls Research Center (LeRC), Cleveland, Ohio, are currently actively involved in work with photovoltaics for DOE, through an agreement with NASA.

\section{A.6.2 kinergy Systems Programs}

The NASA program strategy is to utilize NASA aeronautics and space technologies, experience, and facilities in support of the energy RD\&D program needs of the DOE and other government organizations. The overall goal of the program is the effective use of 
NASA capabilities in the accomplishment of specific technical and programmatic goals resulting from national energy policy.

The program goal is accomplished in two ways. One approach is to identify emerging technology requirements, verify NASA capabilities to effectively support program needs of DOE and other agencies, and prepare soundly conceived technology advancement plans. NASA "seed" money and manpower are used within approved areas of emphasis to prepare the plans for technology advancement. This approach arises because the definition of energy problems and their possible solutions change as the national perception of energy needs and options becomes more clearly defined and also because the NASA aeronautics and space capability continues to develop and expand.

Based on plans agreed upon with appropriate agencies, reimbursable funding is also obtained to conduct specific projects. This second approach permits NASA to continue to be responsive to national energy program needs as they evolve.

The programs consist of three major activities, each of which includes projects wholly funded by NASA. The majority of activities, however, are funded by other agencies.

The NASA-funded activities encompass specific technologies that show the potential to satisfy emerging requirements of other agencies. Examples are:

- Small Integrated Solar Power.Systems. Solar energy technology promises early benefits for remote areas that have ample sunshine but few resources to import scarce, expensive fuels for conventional power systems. Studies have been initiated in FY79 to explore the feasibility and potential for integrating energy technology into small power systems for remote communities in the United States and in less developed countries. The studies will be closely coordinated with AID and DOE with a view to developing of fully reimbursable projects.

\section{A.6.3 Solar Terrestrial}

This program activity encompasses earth-based technologies related to the use of solar and solar-derived energy.

- Solar Heating and Cooling. This is a 5-year DOE program to develop cost-effective, reliable, commercially acceptable solar heating and cooling systems and subsystems and to demonstrate their effectiveness under different climatic conditions. The program has two major components, both of which are managed by NASA's Marshall Space Flight Center (MSFC).

- Development and Demonstration. The purpose of this project is to complete the development of solar heating and cooling systems and components that are essentially "state of the art," but are not yet qualified for use in planned residential and commercial demonstration programs.

- Commercial Demonstration. Contracts under this project lead to demonstration of available solar heating and cooling systems in nonresidential applications. All NASA-managed commercial demonstration projects will be completed by early 1980.

- Photovoltaic Conversion (Solar Cells). The NASA role in support of the DOE Photovoltaic Conversion Program involves long-term (10-year) major participation by NASA's Jet Propulsion Laboratory (JPL) and NASA-Lewis Research Center (LeRC). 
JPL is responsible for advancing to a competitive level production technology for silicon solar cells. LeRC is to develop and test concepts for integrating the solar cell arrays stemming from the JPL project into a variety of practical terrestrial applications. The JPL work is under way, and the major portion has been contracted to industry. JPL's key milestones are to develop the technology for mass production and demonstrate pilot plant operation by 1983, and to establish by 1986 a national capability to produce more than $500 \mathrm{MW}$ per year of solar cell arrays at a cost in 1975 dollars of less than $\$ 500 / \mathrm{kW}$. The principal objectives of LeRC's Photovoltaic Test and Applications Project are to stimulate the nearterm market for the application of photovoltaic systems to determine their operational characteristics, devise measurement and diagnostic techniques, and determine the durability of solar cell systems under realistic conditions.

- Wind Turbo-Generators. I.eR.. manages a major portion of the Wind Energy Program for DOE. DOE has assigned LeRC responsibility for the development of large, horizontal-axis, wind turbo-generators (WTGs). This will require demonstration of a sufficient number of machines in realistic applications to assure the potential for cost-effective commercial operation. A $100 \mathrm{~kW} \mathrm{WTG} \mathrm{(MOD-0)} \mathrm{de-}$ signed and constructed by LeRC at the Plum Brook Station, Sandusky, Ohio, began test operations in September 1975. Four additional machines uprated to $200 \mathrm{~kW}$ (MOD-0A) will be tested in conjunction with small electric-utility companies in New Mexico, Puerto Rico, Rhode Island, and Hawaii. A 1.8 MW TG (MOD-1) was erected late in 1978 on Howard's Knob near Boone, North Carolina, and will begin operation in early 1979. An even larger WTG (MOD-2) is being designed to produce approximately $2.5 \mathrm{MW}$. It is scheduled for first operation late in 1979 at a site yet to be determined.

- Solar Thermal Electric Conversion. JPL is responsible for a relatively new activity in the solar thermal-electric conversion area. JPL's rolc is to help DOE develop its 'Ihermal Power System ProgrälI plun and to manage the advanced technology and small power- system applications portions of the program. LeRC is providing support to JPL in the energy-conversion portion of the work.

- Energy Storage. LeRC is managing the high-temperature, thermal-energy storage portion of the DOE Energy Storage Program. The objective is to develop effective thermal-energy storage systems for use by electric utilities, industrial plants, and dispersed solar energy systems. Energy storage concepts under evaluation include storage of heat energy in both solids and fluids. LeRC is also evaluuting the potential worth of a room-temperature battery as as alternative to the present lead-acid batteries used for utility applications.

\section{A.7 OPFICE OF THE SPECIAI, REPRESENTATTVE FOIR TRADE NEGOTIATIONS}

The Office of the Special Representative for Trade Negotiations was established as an agency in the Executive Office of the President by the Trade Act of 1974 (88 Stat. 1999; 19 U.S.C. 2171) and signed into law January 3, 1975. Its functions are carried out by the authority of the Trade Expansion Act of 1962 (19 U.S.C. 1801) and the Trade Act of 1974, and under authority delegated by the President in Executive Order 11846 of March 27, 1975 , as amended.

A cabinet-level official with the rank of ambassador heads the Office and reports directly to the President. Two Deputy Special Representatives, with the rank of ambassador, and a professional staff constitute the Office. 
Three interagency committees under the direction and control of the Special Representative are: The Trade Policy Staff Committee, the Trade Policy Committee Review Group, and the Trade Policy Committee. The Special Representative is responsible for supervision and coordination of the trade agreements program and directs U.S. participation in trade negotiations with other countries.

\section{A.8 OVERSEAS PRIVATE INVESTMENT.CORPORATION}

The Overseas Private Investment Corporation (OPIC) is an independent agency, created in 1969 (83 Stat. 805; 22 U.S.C. 2191). It received its formal authority in 1971 (Executive Order 11579). OPIC is charged with assisting U.S. investors to make secure and profitable investments in developing countries. OPIC's legislative mandate places emphasis on application of OPIC services for small U.S. businesses.

\section{A.8.1 Present OPIC Services and Programs}

OPIC services are structured to reduce investors risk and to provide financial assistance not otherwise available, that is, to help ease the social and economic problems that undercut the attractiveness of investment in developing countries. Specific services include direct loans to U.S. investors of up to $\$ 5$ million; guarantees to U.S. lenders on loans to U.S. investors of from $\$ 2$ to $\$ 50$ million; insurance for U.S. investors against political risks of expropriation, inconvertibility of currency, and damage from war, revolution, or insurrection; investment information and counseling; and up to $75 \%$ of the cost of feasibility studies (to be repaid as a loan if the studied project is implemented). In joint venture investments, OPIC provides its services for only the U.S. share of the venture.

OPIC programs are available only for new and expansion projects (new facilities, modernization or expansion of existing facilities, or new inputs of technology or services), and OPIC specifically encourages investment projects that are likely to contribute to the economic and social development of the base countries.

\section{A.8.2 Involvement With Photovoltaies}

At this time, OPIC is not and has not been providing services to any investors in photovoltaic production or marketing. However, such investors would have access to OPIC services. As U.S. photovoltaic industries increase their interest in developing commercial outlets in developing countries, OPIC could play a significant role in facilitating their investments.

\section{A.9 THE PEACE CORPS}

The Peace Corps was oreated by Congress in 1961 with the mission of helping people in developing countries to meet their needs for trained citizens, helping promote better understanding of the American people among communities served, helping to increase Americans' understanding of other peoples, and promoting world peace and friendship.

The Peace Corps is a branch of ACTION (an independent agency, created by Reorganization Plan 1 of 1971). It operates through Peace Corps Volunteers (PCVs) who are based in over 60 developing countries. The efforts of PCVs are concentrated ui the local (usually rural) community level and in cooperation and integration with existing programs of na- 
tional governments and international assistance agencies. The Peace Corps itself does not fund projects, but rather provides projects with volunteers for person-toperson transfer of information.

Peace Corps Volunteers have worked primarily in the areas of agriculture/rural development, health, and education. Only very recently has a special concern with energy evolved in the Peace Corps. This new focus on energy is resulting in two new Peace Corps programmatic efforts: (1) design and implementation of studies of village-level patterns of energy use in at least 20 selected sites around the world. These studies will begin during 1979, and will be conducted by PCVs in coordination with interested parties in the site countries. AID and the Overseas Development Council are working with the Peace Corps in the funding and analysis of these studies. (2) Beginning at this time, some new PCVs will receive specific training to enable them to undertake energy-related work in developing countries. A few PCVs already work with energy projects (specifically, PCVs in Upper Volta and Mali are working with AID-sponsored photovoltaic projects); thlis new training program will ensure a cudre of appropriately skilled new vnlunteers over the next severul years.

\section{A.10 THE SMALL BUSINESS ADMINISTRATION}

The fundamental purposes of the Small Business Administration (SBA) are to aid, counsel, assist, and protect the interests of small businesses.

The SBA was created by the Small Business Act of 1953 (67 Stat. 232), and derives its present existence and authority from the Small Business Act (72 Stat. 384; 15 U.S.C. 631 et seq.) as amended. It also derives its authority from the Small Business Investment Act of 1958 (72 Stat. 689; 15 U.S.C. 661), as amended, the Disaster Relief Act of 1970 (84 Stat. 1744; 42 U.S.C. 4401 et. seq.), and $\$ 9$ of the Act of April 20, 1973 (87 Stat. 24). The Secretary of Commerce has delegated to the Administration certain responsibilities and functions under $\$ 202$ of the Public Works and Economic Development Act of 1965 (79 Stat. 556; 42 IJ.S.C. 3142), as amended, and is further authorized to delegate to the Administration certain responsibilities and functions under Chapter 3 of the Trade Act of 1974 (88 Stat. 1978; 19 U.S.C. 2101).

Public Law 95-315, 92 Stat. 377, the "Small Business Energy Loan Act", signed July 4, 1978, directed SBA to implement an energy loan assistance program designed to provide loans and loan guarantees as a means for small business to establish or expand energyrelated businesses. The legislation under $\$ 130.3(\mathrm{~b})$, "Eligible energy measures", reads: "Photovoltaic cells and related equipment. Such devices produce electricity when exposed to radiant energy, especially light. Several devices have been develuped to utilize photovoltaic solur cells. One example is photovoltaic powered solar irrigation pumps." This legislation, particularly with referencee to $\$ 130.3(\mathrm{~b})$, would appear to give SBA the authority to participate in the International Photovoltaic. Plan.

The Small Business Energy Loan Program, prepared by SBA, provides for eligibility, credit requirements, and loan terms to be used in the program. 
APPENDIX B

PROGRAMS AND GOVERNMENT ACTIONS CONSIDERED IN PREPARING THE PLAN 


\section{THIS PAGE WAS INTENTIONALLY LEFT BLANK}




\section{APPENDIX B \\ PROGRAMS AND GOVERNMENT ACTIONS \\ CONSIDERED IN PREPARING THE PLAN}

\section{B.1 INTRODUCTION}

In order to execute the international plan successfully, the proposed program elements had to satisfy a varied group of interests, be in accord with existing statutes and legislation, build on present agency initiatives and plans, and accelerate the widespread use of photovoltaic systems in international markets.

To accomplish the above objectives, the study team consulted a large group of participants. They met with agency representatives and industry officials; considered international financial materials, developing country considerations, and foreign competition; and consulted marketing experts with experience in other industries. These interviews, contacts, and papers produced a list of plan alternatives. The proposed actions were then evaluated by the study team using the criteria listed below:

- accord with legislative intent;

- legality;

- cost; and

- potential for direct and indirect effect in achieving the plan objectives.

\section{B.2 STUDY PARTICIPANTS AND SOURCES}

Assembling a credible and representative project team was one of the important early priorities of the project. The participants fell into three major groups. The first group included U.S. government agencies who would play a role in international photovoltaic developments. This group consisted of members of the expanded International Solar Commercialization Working Group plus other interested agencies. The role of this group was to provide comments on and reviews of all the end products of the project.

Photovoltaic and related industries composed the second group of participants in the study. The photovoltaic industries are key participants in the plan because the plan affects their corporate strategies and its success depends crucially on their actions. The photovoltaic industry was involved through a series of interviews with selected companies. The companies interviewed included:

$\begin{array}{ll}\text { Solar Power } & \text { Varian } \\ \text { RCA } & \text { Photon Power } \\ \text { OCLI } & \text { SES, Inc. } \\ \text { Sensor Technology } & \text { Solenergy } \\ \text { ARCO Solar } & \text { SUNTRAC Corporation } \\ \text { Solarex } & \text { Mobil Tyco }\end{array}$

Other industries also have had experience in exporting high-technology U.S. products. The Illinois Institute for Technology Research Institute (IITRI) marketing panel included several marketing experts with experience in other industries: 
Justin Bereny (international market consultant)

Gastone Chingari (IITRI)

William Watt (international market consultant)

Robert McMenamin (international market consultant)

Benjamin Weiner (Probe International)

I.D. Canton (Strategic Decisions)

Charles Gross (Associate Professor, IIT)

Lawrence Wortzel (Professor of Marketing, Boston University)

Dave Morrison (IITRI)

A number of small subcontractors were also included as participants. The MIT Energy Laboratory (Richard Tabors and Tom Kline) provided expertise on rural development problems. Science Applications, Inc. (Tom Jaras) drew on previous market studies to describe international competition. Strategies Unlimited (John Dayand Robin Sacks) brought extensive knowledge of photovoltaic markets and internutional financing to thc project tean!I.

Finally, other organizations interested in photovoltaics and the international photovoltaic plan were Involved. Through informal mectings and correspondence, ideas and comments were solicited from the Office of Technology Assessment, the Solar Lobby, and the staff of relevant Congressional committees.

Table B-] lists the actions considered and their disposition by the SERI/JPL study team. For reference to the main document of the plan, the recommended actions are arranged by program element headings; i.e., market demonstrations, systems development, supplier assistance, and purchaser assistance. There is an additional category - "other" that encompassed the program management and information clearinghouse functions. 
Table B-1. ACTIONS CONSIDERED AND THEIR DISPOSITION

\begin{tabular}{|c|c|c|}
\hline $\begin{array}{l}\text { Recommend Action/Related } \\
\text { Program Element }\end{array}$ & Source & Disposition \\
\hline \multicolumn{3}{|l|}{ Market Demonstrations } \\
\hline $\begin{array}{l}\text { 1. Fund demonstrations in selected } \\
\text { countries, systems should be country } \\
\text { or region specific. }\end{array}$ & 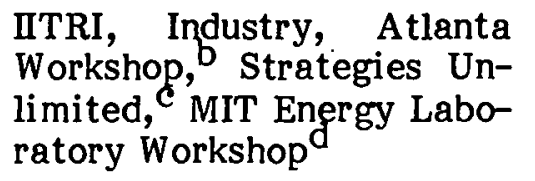 & Adopted. Section 3.0 \\
\hline $\begin{array}{l}\text { 2. Finance country specific market } \\
\text { studies to be completed by PV or PV } \\
\text { systems manufacturers. }\end{array}$ & IITRI, Industry & Adopted. Section 3.0 \\
\hline $\begin{array}{l}\text { 3. Emphasize small village power sys- } \\
\text { tems for PV demonstrations. }\end{array}$ & IITRI & $\begin{array}{l}\text { Adopted, i.e., not precluded in present } \\
\text { plan. However, these systems are pre- } \\
\text { sently extremely costly. }\end{array}$ \\
\hline $\begin{array}{l}\text { 4. Conduct demonstrations in U.S. of } \\
\text { PV systems with export potential. }\end{array}$ & IITRI & Adopted. Section 3.0 \\
\hline 5. Use U.S. PV's in Saudi Project. & ITRI & $\begin{array}{l}\text { Now being considered by responsible U.S. } \\
\text { agencies. }\end{array}$ \\
\hline \multicolumn{3}{|l|}{ Systems Development } \\
\hline $\begin{array}{l}\text { Develop standard basic need type } \\
\text { systems, i.e., pumps, communica- } \\
\text { tions, etc. }\end{array}$ & $\begin{array}{l}\text { IITRI, Agency, Strategies } \\
\text { Unlimited }\end{array}$ & $\begin{array}{l}\text { Adopted. Systems development is pre- } \\
\text { sently ongoing and is taken into account } \\
\text { in plan. Section } 3.0 \text {. }\end{array}$ \\
\hline \multicolumn{3}{|l|}{ Supplier Assistance } \\
\hline 7. U.S. military sales of PV systems. & SERI/JPL Study Team & $\begin{array}{l}\text { Impractical at this time. Based on infor- } \\
\text { mal discussion with responsible agency. }\end{array}$ \\
\hline $\begin{array}{l}\text { 8. Set aside fixed percentage of U.S. } \\
\text { foreign aid for PV applications. }\end{array}$ & SERI/JPL Study Team & $\begin{array}{l}\text { Not practical in view of current agency } \\
\text { and U.S. Government policies. }\end{array}$ \\
\hline $\begin{array}{l}\text { 9. Guarantee loans for international } \\
\text { P.V. projects. }\end{array}$ & $\begin{array}{l}\text { SERI/JPL Study } \\
\text { Strategies Unlimited }\end{array}$ & $\begin{array}{l}\text { Present U.S. Government programs ade- } \\
\text { quate for this action. }\end{array}$ \\
\hline
\end{tabular}


Table B-1: ACTIONS CONSIDERED AND THEIR DISPOSITION (continued)

\begin{tabular}{|c|c|c|c|}
\hline & $\begin{array}{l}\text { Recommend Action/Related } \\
\text { Program Element }\end{array}$ & Source & Disposition \\
\hline 10. & $\begin{array}{l}\text { Exclusive company rights to mar- } \\
\text { ket studies }\end{array}$ & ITRI & $\begin{array}{l}\text { Not ajopted on basis of anti-trust con- } \\
\text { siderations. }\end{array}$ \\
\hline 11. & $\begin{array}{l}\text { Government grants for research } \\
\text { production methods. }\end{array}$ & HTRI & $\begin{array}{l}\text { Not adopted on basis this activity dupli- } \\
\text { cates work being done under domestic PV } \\
\text { program. }\end{array}$ \\
\hline 12. & $\begin{array}{l}\text { Government funding of pilot sys- } \\
\text { tems assembiy line. }\end{array}$ & SERI/JPL Study Team & $\begin{array}{l}\text { Not dopted. Duplicates domestic PV } \\
\text { program activities and proposed plan ac- } \\
\text { tivities. }\end{array}$ \\
\hline 13. & $\begin{array}{l}\text { Prototype development and testing } \\
\text { done with joint U.S. and developing } \\
\text { country participation. }\end{array}$ & ITRI & Adopted. Section 3.0 . \\
\hline 14. & $\begin{array}{l}\text { Negotiate cooperative agreements } \\
\text { so contractor retains all patent } \\
\text { rights. }\end{array}$ & IITRI & $\begin{array}{l}\text { Not adopted. Present DOE patent policy } \\
\text { adequate for plan. }\end{array}$ \\
\hline 15. & $\begin{array}{l}\text { Remove licensing restriction on PV } \\
\text { systems. }\end{array}$ & IITRI & $\begin{array}{l}\text { May or may not be adopted, i.e., plan } \\
\text { calls for a review of U.S. regulations and } \\
\text { tax statutes affecting P.V.'s. }\end{array}$ \\
\hline 16. & $\begin{array}{l}\text { Encourage comprehensive trade } \\
\text { promotion activities. }\end{array}$ & Industry & $\begin{array}{l}\text { Adopted. See entire plan and Section } \\
4.0 \text {. }\end{array}$ \\
\hline 17. & $\begin{array}{l}\text { Establish informal PV advisory } \\
\text { committee for market studies. }\end{array}$ & Agency recommendation & Adopted. Section 3.0. \\
\hline 18. & $\begin{array}{l}\text { Negotiate lower tariffs ¿or PV sys- } \\
t \in m s \text {. }\end{array}$ & ITRI & $\begin{array}{l}\text { Not adopted. Present U.S. policy is to } \\
\text { see. lower tariffs for all U.S. products. }\end{array}$ \\
\hline 19. & $\begin{array}{l}\text { Favorable ccoperative agreements } \\
\text { tc promote PV systems. }\end{array}$ & ITRI & Adopted. See Section 3.0. \\
\hline
\end{tabular}


Table B-1. ACTIONS CONSIDERED AND THEIR DISPOSITION (continued)

Recommend Action/Related ${ }^{\mathrm{a}}$

Program Element

20. Conduct workshops on marketing in selected areas.

21. Improve communications jetween manufacturers and U.S. Government.

22. Government guarantee bid bonds.

23. Provide travel expenses for salesmen.

24. Support solar trade fairs and other trade promotion activities.

25. Warranty Insurance provided by U.S. Governement.

26. Tax credits for PV export and R\&D expenses.

27. Tax concessions to banks for foreign solar loans.

28. Prepare outreach material informing U.S. companies of U.S. Government programs and capital opportunities.

29. Provide capital loans to PV companies for export activities.

\section{Source}

Disposition

Atlanta Workshop ${ }^{b}$

Atlanta Workshop ${ }^{b}$, ITRI, Industry

\section{SERI/JPL Study Team}

SERI/JPL Study Team, IITRI

SERI/JPL Study Team, IITRI, Atlanta Workshop ${ }^{\mathrm{C}}$

SERI Staff Member

IITRI, Atlanta Workshop ${ }^{b}$, Strategies Unlimited ${ }^{\mathrm{c}}$

Strategies Unlimited ${ }^{c}$

ITRI, Atlanta Workshop ${ }^{b}$

SERI/JPL Team, Strategies Unlimited $\mathrm{C}$
Not adopted. This recommendation would duplicate present U.S. DOE activities

Adopted. Section 3.0 and 4.0.

Not adopted. Present U.S. activities adequate. Other program elements were judged better options.

Not adopted. Violates International trade agreements.

Adopted. Section 3.0.

Not adopted. Would be studied in review of current U.S. regulations and tax statutes.

Not adopted. Will be studied by program office at part of review of U.S. tax statutes. Section 3.0.

Not adopted. Will be studied by program office as part of review of U.S. tax statutes. Section 3.0.

Adopted. Section 3.0.

Not adopted. Probably illegal based on informed agency discussion. 
Table B-1. ACTIONS CONSIDERED AND THEIR DISPOSITION (ant inued)

\begin{tabular}{|c|c|c|c|}
\hline & $\begin{array}{l}\text { Recommend Action,'Related }{ }^{\mathrm{a}} \\
\text { Program Element }\end{array}$ & Source & Disposition \\
\hline 30. & $\begin{array}{l}\text { Formation of a photovoltaic export } \\
\text { company. }\end{array}$ & IITEI & $\begin{array}{l}\text { Not adopled. Would take too long to im- } \\
\text { ple nent } \varepsilon \text { r.d there are considerable poli- } \\
\text { tical p:ablems in developing such a } \\
\text { recommendation. }\end{array}$ \\
\hline 31. & $\begin{array}{l}\text { Protection by foreign goverrments } \\
\text { of U.S. PV license. }\end{array}$ & IITRI & $\begin{array}{l}\text { Impract:ca- for U.S. Government to take } \\
\text { suci role. }\end{array}$ \\
\hline 32. & $\begin{array}{l}\text { Amendment of Rojinson Patman } \\
\text { Act to favor photovaltaics. }\end{array}$ & IITRI & $\begin{array}{l}\text { Imfractica- and not needed based on in- } \\
\text { formal agency discussions. }\end{array}$ \\
\hline 33. & $\begin{array}{l}\text { Permit different pricing in differ- } \\
\text { ent countries but not lower than in } \\
\text { U.S. }\end{array}$ & IITRI & $\begin{array}{l}\text { Apparently nct illegal now. Company } \\
\text { warting to do this should seek Depart- } \\
\text { ment of Justice guidance. }\end{array}$ \\
\hline 34. & $\begin{array}{l}\text { Seek low cost Small Business Ad- } \\
\text { ministration loans. }\end{array}$ & IITRI & $\begin{array}{l}\text { Not adopt } 2 \text {, i.e., companies may now do } \\
\text { so, no plar: ecommendation needed. }\end{array}$ \\
\hline 35. & $\begin{array}{l}\text { U.S. Government should guarantee } \\
\text { against appropriation of U.S. PV } \\
\text { firms aperation overseas. }\end{array}$ & ITTR- & $\begin{array}{l}\text { Not adopted. Present general U.S. policy } \\
\text { is adequat?.. }\end{array}$ \\
\hline 36. & $\begin{array}{l}\text { Guarantee loans for U.S, sales in } \\
\text { foreign countries. }\end{array}$ & $\begin{array}{l}\text { SERL/JPL Study Team, } \\
\text { Atlanta Workshop }\end{array}$ & Not adopted. Already present policy. \\
\hline 37. & $\begin{array}{l}\text { U.S. Government provide matching } \\
\text { funds for each PV sell exported. }\end{array}$ & SERI/JPL Study Team & $\begin{array}{l}\text { Not adopted. Not in accordance with } \\
\text { present U.S. trade treaties. }\end{array}$ \\
\hline 38. & $\begin{array}{l}\text { U.S. Government certifies syistems } \\
\text { and provides labels. }\end{array}$ & SERI/JPL S1udy Team & $\begin{array}{l}\text { Not adopted. Duplicates existing stan- } \\
\text { dards work. }\end{array}$ \\
\hline
\end{tabular}


Table B-1. ACTIONS CONSIDERED AND THEIR DISPOSITION (continued)

\begin{tabular}{|c|c|c|c|}
\hline & $\begin{array}{l}\text { Recommend Action/Related } \\
\text { Program Element }\end{array}$ & Source & Disposition \\
\hline 39. & $\begin{array}{l}\text { U.S. Government identify potential } \\
\text { buyers. }\end{array}$ & IITRI & $\begin{array}{l}\text { Not adopted. This role left to systems } \\
\text { houses and manufacturers. }\end{array}$ \\
\hline$\frac{\text { Purch }}{40}$ & $\begin{array}{l}\text { haser Assistance } \\
\text { Send information packages on PV's } \\
\text { to embassies. }\end{array}$ & Agency, Atlanta Workshop ${ }^{\mathfrak{a}}$ & Adopted. Section 3.0 . \\
\hline 41. & $\begin{array}{l}\text { Educate embassy personnel on } \mathrm{PV} \\
\text { potential. }\end{array}$ & ITRI & Adopted. Section 3.0. \\
\hline 42. & $\begin{array}{l}\text { Provide input into courtry five- } \\
\text { year plans. }\end{array}$ & IITRI & $\begin{array}{l}\text { Not adopted. This role more easily left } \\
\text { to countries themselves. }\end{array}$ \\
\hline 43. & $\begin{array}{l}\text { AID assist least developed count- } \\
\text { ries (LDCs) with design and specifi- } \\
\text { cations for PV systems. }\end{array}$ & Strategies Unlimited ${ }^{\mathbf{c}}$ & Adopted. Section 3.0 . \\
\hline 44. & $\begin{array}{l}\text { Train foreign students, potential } \\
\text { customers, and elite in photo- } \\
\text { voltaic technology. }\end{array}$ & IITRI & Adopted. Section 3.0. \\
\hline 45. & $\begin{array}{l}\text { Provide training materials on PVs } \\
\text { and PV systems. }\end{array}$ & IITRI & Adopted. Section 3.0. \\
\hline 46. & $\begin{array}{l}\text { Involve Non-Government organiza- } \\
\text { tions in demonstrations and PV } \\
\text { activities. }\end{array}$ & $\begin{array}{l}\text { MIT Energy Laboratory } \\
\text { Workshop }\end{array}$ & Adopted. Section 3.0. \\
\hline 47. & $\begin{array}{l}\text { Educate banking community on PV } \\
\text { potential. }\end{array}$ & Strategies Unlimited ${ }^{c}$ & Adopted. Section 3.0. \\
\hline 48. & $\begin{array}{l}\text { Prepare promotional materials for } \\
\text { PV systems. }\end{array}$ & IITRI & Adopted. Section 3.0 \\
\hline$\frac{\text { Other }}{49 .}$ & $\begin{array}{l}\text { International economic analysis } \\
\text { program. }\end{array}$ & Strategies Unlimited & $\begin{array}{l}\text { Referred to DOE/Program Office, if } \\
\text { named. }\end{array}$ \\
\hline
\end{tabular}


Table B-1. ACTIONS CONSIDERED AND THEIR DISPOSITION (concluded)

Recommended Action $/$ Related ${ }^{\mathrm{a}}$

Program Ellement

Source

Disposition

50. Inform PV manufacturers and systems houses on present U.S. GorIITRI, In
Workshop ernment pclicies ar:d programs.

51. Dne stop clearinghouse to deal with PV's withint the U.S. Government.

Industry,
Workshop

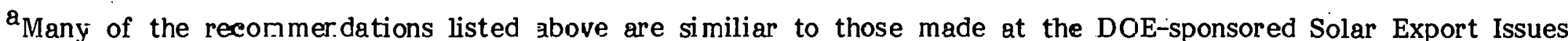
Worksinop held in Bethesia, Maryland, August 13, 14, 1979. Because these recommendations were directed at all of the soiar technolggies and not specifical-y directed at photovoltaics, they are not cited.

bepartment of Energy. April 1979. DOE/Solar Export Opportunity Workshof in Atlanta, Georgia, SERI Report No. TP-49-186. Colden, CO: Solar Ener כy Research Institute, pp 177-181.

'Strategies Unlimited. A.ugust 1979. Impact of International Financial Institutions on Markets for Solar Energy Systems. Mountain View, CA: Strategies Unlimited, pp. 17-19.

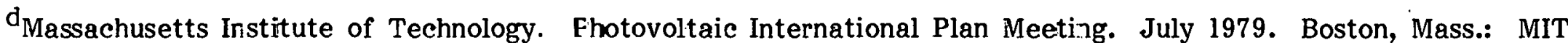

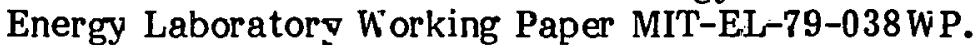


APPENDIX C

INTRODUCTION TO PHOTOVOLTAIC TECHNOLOGY 
THIS PAGE

\section{WAS INTENTIONALLY $\therefore$ LEFT BLANK}




\section{APPENDIX C \\ INTRODUCTION TO PHOTOVOLTAIC TECHNOLOGY}

\section{C.1 INTRODUCTION}

Solar photovoltaic energy conversion is one of the half-dozen technologies that comprise the solar option.* Photovoltaic technology exhibits both strong attributes and difficult implementation problems.

Like all solar technologies; the source of photovoltaics is inexhaustible. Photovoltaic cells provide direct conversion of solar radiation to energy in the most refined of all forms, electrical power. Economies of scale do not dominate photovoltaics as they do some of the other solar technologies. Applications encompassing all size ranges may be considered. The solar cell is also a fundamentally simple structure that uses available raw materials, has a strong existing industrial manufacturing base, and requires little special knowledge or skills to use.

The basic problem with photovoltaic conversion, as with most solar technologies, is cost. At circa 1977 prices for solar cells of $\$ 11$ per peak watt $\left(W_{p}\right)$ of output, the cost of photovoltaic energy would be $\$ 1-2 / \mathrm{kWh}$ or 20 times the competitive range for utilitygenerated power in the United States. This cost is competitive for some applications space satellites, communications equipment, corrosion protection for bridges and pipelines, aids to navigation, and others that do not have ready access to the utility power grid. However, the total nongovernmental demand for solar cells at $\$ 11 \mathrm{~W}_{\mathrm{p}}$ is well below $1 \mathrm{MW}$ of peak capacity per year and does not yet provide the base for the multi-MW annual production levels that will be required to reach DOE's price goals for solar cell modules: $\$ 2 / \mathrm{W}_{\mathrm{p}}$ by 1982 and $\$ 0.50 / \mathrm{w}_{\mathrm{p}}$ by 1986 ( 1975 dollars).

\section{C.2 PHOTOVOLTAIC EFFECT}

A photovoltaic device converts light energy (photons) into electrical energy (a voltage). This phenomenon is known as the photovoltaic effect and involves the excitation of electrons by absorption of light, thus permitting their movement through a semiconductor material.

Materials are referred to as semiconductors because they conduct electricity only if they contain appreciable numbers of electrons can be excited across a band of energy states (a band gap) into the conduction band. Conductors, such as copper, have no band gap. When semiconductors are specially treated or doped, they are capable of converting incident energy (light) into electrical energy. Therefore, solar cells are special types of semiconductors.

In a photovoltaic cell the conversion of light to electricity is accomplished by electrons that absorb energy from photons and jump to higher energy states. The electronic energy transition is followed by a separation of electrons and vacant energy states or "holes" producing a distribution of charge that çauses a difference in voltage between the front (sunlight side) and back of the solar cell on the order of half a volt.

*Others are solar thermal, solar thermal electric, wind, ocean thermal, and bioconversion. 
A silicon solar cell is typically a thin $(1 / 4 \mathrm{~mm})$ wafer, approximately $5-10 \mathrm{~cm}$ in diameter, consisting of two layers. Materials other than silicon can be used for photovoltaic cells and are the subject of $R \& D$ efforts at the present time. Among these materials are gallium arsenide (GaAs), cadmium sulfide (CdS), copper sulfide $\left(\mathrm{Cu}_{2} \mathrm{~S}\right)$, and indium antimonide (InSb). Whatever the material, the essential features of a photovoltaic cell are the same.

\section{C.3 PHOTOVOLTAIC SYSTEMS}

Solar cells are only one part of complete solar photovoltaic power conversion systems. A photovoltaic system contains array structures to support the modules, circuitry to control and modify output in various ways, and a means of storing energy, if required.

The cost of the array structures that support the modules ale estimated to he a signifisant portion of photovoltule system cost. Ancillary rircuitry also may be costly; tlie direct current (DC) produced by solar cells in some applications must be changed to alternating current (AC) used by most elcctrical loads and utility systems. For many applications, electrical storage is needed to provide electrical power when the array is not producing power or to supplement the array output during transient loading. In addition, a means of regulating the flow of power among the solar array, energy storage, and load are of ten required. The exact design and balance of system costs depend on the application in which the system will be used. Also, the word "system" may be defined to include the application; e.g., a photovoltaic-driven pump.

The flat-plate collector, or array, is composed of a number of panels which, in turn, contain the photovoltaic cells. The cells and panels are connected in series and are parallel to provide the voltage and current output ratings required by the individual application. The cells in the panels are covered with clear plastic or glass and are sealed against environmental elements. The output per unit area is dependent on the packing density and other efficiency and degradation factors.

Solar arrays are expected to be highly reliable and nearly maintenance free. The principal cause of failure in photovoltaic arrays is the corrosion of electrical contacts after moisture penetrates the array through lamination separations and other "packaging" failures. Few data defining the life of arrays are available. However, it is believed that the packaging problem can be overcome as the technology matures, so that array lives of 20 years and more are probable.

Currently, commercial systems that service relatively small operating power requirements employ lead-acid batteries as the storage medium. The characteristics of batteries used with photovoltair systems vary among applicatiuns. For photovoltaic systems operating in an augmentation mode, shallow discharge cycles mny compensute for passing clouds and other brief interruptions. However, long lives with deep discharge cycles will be required for solar energy systems to provide continuous power supplies during long, periods without sunlight. High discharge rates may also be required to provide instantaneous power when induction motors are on line.

Power conditioning units contain two components: a power inverter and a shunt regulator. The purpose of the inverter is to transform the $\mathrm{DC}$ electricity received from the collector or electric storage device into AC, which may be needed for some applications. Several types of inverters exist that are appropriate to use with photovoltaic generators. In many applicatons, a photovoltaic system is replacing another DC power source, such as primary batteries or thermal electric generators. For these systems, no inverter is needed. Shunt regulators are used to prevent overcharging of the batteries. 


\section{C.4 SILICON MODULE PRODUCTION PROCESS}

While there are many types of materials that can function as photovoltaic cells, there are also a multitude of ways in which silicon photovoltaic cells can be fabricated and manufactured into photovoltaic modules. These technologies generally are classified as ingot, noningot, or concentrator technologies.

The present production process for silicon solar cells (ingot) begins with quartz, a relatively pure form of $\mathrm{SiO}_{2}$. This is reduced to metallurgical-grade silicon. The next step is to refine the silicon to semiconductor-grade. The purity, cost, and production volume of this material is determined by the requirements of the semiconductor industry, since that industry uses most of the high-purity silicon produced. The purity and quantity requirements of silicon solar cells are sufficiently different that a growing demand for solar power devices would be likely to result in production of a lower purity, lower cost, solargrade polycrystalline silicon.

Next, the semiconductor-grade, or polycrystalline, silicon is recrystallized to form single-crystal silicon by a method called the Czochralski process, a technique commonly used in the semiconductor industry. The first step in this process is to melt the semiconductor-grade silicon and dope it with very small quantities of other elements (boron, phosphorus) to make it n-type or p-type. A small silicon seed crystal is then dipped in a pool of the molten semiconductor-grade silicon to initiate crystal growth and withdrawn slowly, pulling with it a large, growing, cylindrical single crystal of silicon (a boule). Depending on the speed of pulling and the rate of cooling, boules of 7-10 $\mathrm{cm}$ in diameter are produced. Larger diameters have advantages in production efficiency, and research into larger boules has yielded diameters as large as $30 \mathrm{~cm}$.

The Czochralski crystallization process is followed by a sawing step to cut the cylindrical boule into flat wafers. The present sawing technique might be improved by reducing the width of the saw blades and the thickness of the wafers. Silicon is wasted in sawdust and in unnecessarily thick wafers.

Then, the wafers are doped with an impurity that is the opposite of the one used in the crystallization process. These impurities diffuse in a short distance into the surface of the cell as the wafers are heated in an oven. Most photovoltaic cells are made of p-type wafers with a thin n-type layer on the sunlit side.

Metal contacts are applied to the front and back of the wafers, and antireflective coatings are applied to the front of the cells to reduce the amount of solar energy which is lost as reflection from the front surface of the cell. The finished solar cells are wired in series, in parallel, and encapsulated in glass or plastic for weatherproofing to form an array.

Analyses indicate that, with improvements in production techniques, ingot technology has a high probability of leading to modules produced at $\$ 2.00 / \mathrm{W}_{\mathrm{p}}(1975)$ in the near future. Further reductions in the cost of ingot-produced arrays are also possible.

The second process, noningot technology, involves the creation of a thin crystalline silicon sheet as opposed to an ingot. This is accomplished by pulling a continuous ribbon or web of material from a replenished melt. This process uses silicon material (similar to polycrystalline silicon used for ingot solar cells) much more conservatively by avoiding sawing losses since slicing is no longer required. The packing density also improves since rectangular cells, rather than round cells, result. It is possible that noningot arrays could be produced for $\$ 0.50 / W_{p}$ or less by 1986 . 
10

There are no obvious barriers to the production of photovoltaic concentrating systems, which today use single-crystal silicon cells. Photovoltaic concentrators use special mirrors or lenses to focus incident light on the photovoltaic cell. Some concentrating arrays are designed to track the sun's path to maximize the energy collected. Concentrators require fewer solar cells and, therefore, the total cost of photovoltaic cells required for a given area of collector is low (a direct inverse function of concentration ratio). The technologies required to manufacture concentrating Fresnel lenses and mirrors are well known, as are the production processes of tracking systems. Production and design improvements that could reduce concentrator costs are being examined now. $R \& D$ efforts are also being directed at high-efficiency cells for use in concentrators (such as gallium arsenide). 


\section{APPENDIX D \\ CHARACTERZATION AND ASSESSMENT OF POTENTIAL EUROPEAN AND JAPANESE COMPETTION IN PHOTOVOLTAICS \\ (Summary)}

Prepared by

SCIENCE APPLICATIONS, INC. 
THIS PAGE

WAS INTENTIONALLY

LEFT BLANK 
CHARACTERIZATION AND ASSESSMENT OF POTENTIAL EUROPEAN

AND JAPANESE COMPETITION IN PHOTOVOLTAICS

\section{SUMMARY}

The objective of this study is an assessment of the potential of European and Japanese firms to produce and market photovoltaic (PV) power systems internationally in competition with firms in the United States. The work was performed by Science Applications, Inc. for the Solar Energy Research Institute, Golden, Colorado, in support of the development of the International Photovoltaic Program Plan for the U.S. Department of Energy.

The study consists of three distinct parts: (1) an overview of worldwide export activity which describes the general posture of select European countries and Japan; (2) an assessment of European competition focusing on Germany, France and the United Kingdom; and (3) an assessment of Japanese competition. This last section on the Japanese competitive position was based on a previous study by Science Applications, Inc. prepared for the Department of Energy, Export Potential for Photovoltaic Systems, Preliminary Report, April 1979.

The study is. limited in scope to an evaluation of existing literature in photovoltaic technology and international marketing trends. Data on specific Japanese and European marketing plans were not available for analysis during the study period. Within this framework we attempt to point out what is possible in the photovoltaic export area, drawing as much on historical perspectives in allied 
fields as on market projections of PV systems. All research was conducted within the United States. Sources of data included published reports in the scientific, trade, and business press, firm's annual reports, telephone interviews with representatives of European and Japanese firms, and a review of the findings of three U.S. groups that had recently toured Japanese photovoltaic firms. European and Japanese government representatives were also interviewed and government program descriptions evaluated. Overview of Worldwide Export Activities (Section 2.0):

The approach used to analyze the European marketing position throughout the world involved looking at two levels of competition. First, the world was divided into four major regions-Asia, Africa, the Middle East, and Latin America-and the competitors within each region were studied in terms of all imports. With the exception of Australia and New Zealand, the emphasis was on developing countries. This reflects the current view that the most promising applications of photovoltaics are in developing countries, where there is of ten a strong demand for off-grid electric power.

Within each region; the import markets were analyzed for three product areas: (1) telecommunication equipment - telephone, telegraph equipment, non-broadcast and broadcast radio and television, data communications equipment, microwave systems, and communications test equipment; (2) electric power equipment - diesel generators and other generation equipment and cables, transformers, and other transmission and distribution equipment, and (3) agricultural equipment. Of the available product areas, these were believed to be 
most closely related to the photovoltaic power systems markets.

Together the top three European exporters-Germany, United Kingdom, and France-exported $\$ 241$ billion of goods in 1977 , which amounted to $35.5 \%$ of the exports of all industrialized countries. In 1977, Germany, the world's second largest exporter, totaled $\$ 118$ billion in exports.

For the past twenty years, Japan has been one of the leading world exporters. In 1977, Japan exported $\$ 31.125$ billion, which was $11.9 \%$ of the $\$ 677$ billion exported by all industrialized countries. Only two countries, the United States ( $\$ 1.20$ billion) and Hest Germany, exported more than Japan in 1977. France and the United Kingdom were fourth and fifth, respectively. All five of these countries sold more than half of their exports to industrialized countries or oil exporting nations. Of these five countries, Japan had the largest share of exports, $45.7 \%$, to countries outside these two categories. This suggests that all five countries devote roughly the same amount of attention to the same markets.

Japan is successfully exporting to all regions of the world and retains the strongest marketing position in Asia, where it supplies a large fraction of the imports of Australia, New Zealand, and Southeast Asia. Although Japan has a special advantage in this region due to its proximity, it faces strong competition from other major exporting nations. The Middle East and Latin America are not Japanese strongholds, but the Japanese provide a significant share of the total imports. Japan is not very active in Africa, particularly Francophone Africa. 
Japan is a serious competitor in the markets for telecommunications equipment and electric power equipment worldwide. Japan is often strong in radio and television equipment, but in both product categories, its strength varies considerably from country to country. In both products, Japan usually faces strong competition from the United States and Hest Germany while France and the United Kingdom provide competition only in select regions. Japan is not prominent in the markets for agricultural equipment, with the exception of Asia. However, recent expansion of their market share in Australia, Phillippines, and Mexico illustrate Japan's ability to move from a relatively minor position to a dominant position very quickly in relevant product lines. Germany, the most successful European exporter, is not the leading supplier to any of the thirty-three countries examined. However, Germany is among the top three suppliers to twenty-three of those nations, and is frequently the second largest supplier, such as Latin America or North and West Africa. Germany is a strong competitor in the markets for telecommunications equipment and electrlc power equipment, two of the product markets examined in this study. Germany is particularly successful in selling at least one of these products in countries having subsidiarles of Stemens (the major German electric and electronic equipment firm).

The United Kingdom is a less successful exporter on the world market. Although a strong supplier of imports to former colonies, the UK is one of the top three suppliers to only eleven of the thirtythree nations studied. The UK is a major exporter of telecomunications, 
electric power, and agricultural equipment,to Africa, but is much less successful than Germany in selling telecommunications and electric power equipment to other regions of the world.

. French exports focus on former colonial areas in North and West Africa. Overal1, France is the least important of the three European countries in the other regions of the world. Excluding North and West Africa, France is one of the top three suppliers to only one nation of the thirty-three countries studied. France is rarely a major supplier of any of the three products examined in this study (telecommunications equipment, electric power equipment, and agricultural equipment).

European Competition (Section 3.0):

European competition is addressed in three distinct areas: the characterization of the PV industry, the current and potential marketing activity, and the status of PV and related technological developments. In characterizing the PV industry in Europe, the focus is on a description of the firms currently active in photovoltaics. The firms addressed include: AEG Telefunken, llacker-Chemie Gmbh, Philips, RTC, LEP, France-Photon, Photowatt International, Ferranti and llontedison. The European PV industry is comprised of a few large multinational corporations, most of which are active in electrical and electronic equipment and telecommunications equipment. A few are major firms with impressive capabilities in silicon materials. All support internal R\&D programs.

Also addressed are the recent links between the U.S. 
photovoltaic industry and European firms, particularly the activity with French corporations. Joint ventures with U.S. PV manufacturers provide European firms with advanced PV manufacturing capabilities, a proven PV product, and access to U.S. R\&D results. In turn,U.S. manufacturers benefit from capitalization, improved market position, and access to European R\&D.

Today U.S. manufacturers dominate the world market with European production representing about 18 percent of the world total for 1979.' Only Philips is currentiy a major competitor although Telefunken and Japanese firms could be major competitors in the next few years. The European presence in the world photovoltaics market is closely linked with national government development funding. French development assistance is largely responsible for the attention Hest Africa is receiving today as a major potential market. Geman exposure overseas is almost exclusively related to government development activities in support of PV demonstrations: The current focus of European firms and U.S. exporters on the Francophone African markets reflects early French attention in this area. Europeans view the major PV markets to be in developing countries and other regions where central station grid-power is not available.

Throughout Europe a large number of universities, research institutions, and industrial research centers are performing R\&D work related to photovoltaic systems. The total government funds available for this R\&D is in excess of $\$ 35$ million annually, France and Germany providing more than 85 percent of the total. U.S. R\&D today is in a lead 
position in most areas of European R\&D activity. The notable exception is the cast ingot polycrystalline effort in Germany.

If a cell technology "breakthrough" occurs at a European research center, the U.S. is in a position to develop that technology rapidly. If the reverse happens, at least one European country will be able to develop the technology quickly. This reflects the focused programs of European programs in comparison to the broader U.S. programs.

Japanese Competition (Section 4.0):

Since Horld Har II Japan's industry has developed several groups of strong manufacturing firms--each with activities in the electrical, electronics, and semiconductor areas. Soon after the photovoltaic cell was invented at AT\&T's Bell Labs in the mid-1950's, Japanese firms began to manufacture cells on a pilot basis. While devoting major resources to transistor and later integrated circuit production, each major group member has maintained activity in photovoltaic cell research, development, and manufacture.

There are about ten companies in Japan which are actively involved in photovoltaic production, or which have the potential, based upon similar product lines, to enter the field quickly. These firms are very large, having annual total sales in the range of 1 to 10 billion dollars. Semiconductor sales and, in particular, photovoltaic sales comprised a small fraction of the total sales. This situation appears to be typical of most Japanese PV manufacturers. Extensive exporting of numerous products has allowed the seven major 
companies combined to establish affiliate companies in 22 countries, subsidiary companies in 9 countries, and branch offices in 51 countries. The sales and distribution networks of these companies are prepared for increased marketing and export of photovoltaic devices.

Total Japanese sales are estimated to range between 30 and $50 \mathrm{KWp}$ in 1978 and maximum Japanese production today is between 40 and $80 \mathrm{KWp}$. Two general observations can be made: domestic sales are small and depend mainly on government purchases. Secondly, foreign sales are limited and the module prices high. The Japanese domestic market is not impressive. It is expected to develop slowly and perhaps reach 200-400 K.Jp annual sales in 1985. A small potential market exists because the country has a highly developed central utility grid and few undeveloped regions.

In the area of foreign sales, Japanese export activities can be summed up as exploratory. Japan exports PV systems to a wide range of countries in Africa, South America, and Asia. Australia is considered a leading market area. Most U.S. PV companies state that they rarely compete with Japanese products. A partial reason for this is that the world PV market is extremely fragmented today. This is characterized by small volume sales over broad geographical regions. It is not uncommon to meet few competitors except where the potential salns are of significant size and frequency.

"Project Sunshine", the broad Japanese government R\&D program in solar energy, includes work on photovoltaics; the program emphasis is on cell fabrication techniques, especially those related to mass 
production. All major cell technologies are represented, including several on edge defined film feed, plasma and chemical vapor thin film deposition, ion beam and conventional epitaxial thin film growth, and polysilicon production.

Photovoltaic R\&D outside of "Project Sunshine" is underway at several universities and private companies. This includes work on emerging materials and amorphous silicon. There is little detailed published information available on most of the research efforts, but that which is available indicates that the Japanese are no more than a year or two behind the United States' effort in the areas they actively pursue. The Japanese R\&D program allows researchers in Japan to keep abreast of the development throughout the world, but the 1 imited funding and broad program scope restricts the researchers' role from leading technological developments.

The Japanese RaD effort in photovoltaics reflects an interest to keep up with worldwide technological developments, but little emphasis is placed on market stimulation or systems development specifically for photovoltaics. This posture will allow Japanese industry to exploit breakthrough or technological developments made in photovoltaics, but minimizes the risk involved.

At present Japan is not a major factor in the photovoltaic power system market; the United States is. Despite this fact the authors believe that Japanese firms have the potential to capture the major share of the world market in a time frame of about twenty years. 
This will become true if several assumptions are valid concerning the probability of technical and manufacturing breakthroughs in photovoltaic power, growth of market demand, a determined national push by Japan, and a lack of concerted effort to promote U.S. PV exporters. 


\section{APPENDIX E}

INDUSTRY PERSPECTIVES ON INTERNATIONAL MARKETS FOR PHOTOVOLTAICS 


\section{THIS PAGE}

\section{WAS INTENTIONALLY \\ $\mathbb{L E F T ~ B L A N K}$}




\section{APPENDIX E \\ INDUSTRY PERSPECTIVES ON \\ INTERNATIONAL MARKETS FOR PHOTOVOLTAICS}

\section{E.1 INTRODUCTION}

SERI visited 13 selected companies currently active in the photovoltaic industry to gather opinions on international markets and the International Photovoltaic Program Plan. Table E-l identifies the companies and individuals interviewed. Seven of the interviewed companies currently are producing photovoltaic modules; six are potential producers but are not actively marketing photovoltaics today. The companies participating do not include all companies active in photovoltaic $R \& D$ and production. However, they do represent the majority of current production, the diverse technological approaches under investigation, and the various types of companies with photovoltaic programs. Figure E-1 characterizes the companies by financial backing and primary business and by business status.

The interviews were informal. Topics discussed included: current international applications and customers; future international applications and customers; obstacles to making international sales; business and marketing arrangements for international sales; international competition; and the role that should be played by the federal government in facilitating international sales. Each of these topics is discussed in the following sections.

\section{E.2 CURRENT APPLICATIONS AND CUSTOMERS}

Photovoltaic systems are currently being sold by U.S. manufacturers for a wide variety of applications in many different countries. Current applications include systems for communications, cathodic protection, navigational aids, educational television, small scale pumping, and remote general power. All of these current applications have been previously identified in publicly available market studies or analyses of past industry sales. Several companies have made photovoltaic system sales in over thirty foreign countries. Others' sales have been confined to fewer countries. Sales have ranged from European countries to the Middle East, Africa, South America, and Australia.

Photovoltaic power systems are sold internationally to three types of customers. First, original equipment manufacturers buy photovoltaic modules for use with equipment subsequently sold to foreign governments, utilities, or private companies. Navigational aids are good examples of photovoltaic systems sold in this way. Other sales are made to system houses which then resell complete systems to foreign governments or private users, or install the photovoltaic system and equipment it powers as part of foreign development projects. Communication and pumping systems are examples of systems of ten sold under this arrangement. A third type of sale is made directly by the photovoltaic module manufacturer or its affiliate to a foreign government, utility or private user. The relative importance of these sales channels is not known; it is likely to vary significantly from company to company depending on company strategy and position. 
Table E-1. COMPANIES AND INDIVIDUALS PARTICIPATING IN STUDY

\section{CURRENT PRODUCERS}

Company

Solarex Corporation

Solenergy Corporation

Sensor Technology, Inc.

Optical Costing Laboratory, Inc.

Motorola Semiconductor Products, Inc.

ARCO SOLAR, Ine.

Solar Power Corporation
Individuals Interviewed

Joseph Lindmayer, President John Goldsmith, Vice President Ted Blumenstock, Director of Marketing

Robert Willis, President

Irwin Rubin, President

Sunjeev Chitre, Direetor, Solur Operations

Kees Van Der Pool, Vice President of Marketing

Douglas O'Connor, President, Photoelectronics Division

Raymond Mattison, Manager, Corporate Market. Development

Robert Brown, Manager, Terrestrial Solar Power Programs

Bill O'Connor, Director, Solar Energy Robert McGinnis, Manager, Bolar Opcrationo

T. D. McLaughlin, Vice President and General Manager

J. W. Yerkees, Vice President, Engineering and Research

Kenneth Ude, Coordinator, Market Research

W. W. Hawley, Manager of Programs

John Wurmcer, President Paul Caruso, Vice President William Brusseau, Marketing Manager

POTENTIAL PRODUGERS

Sun Trac Corporation

RCA
Douglas Moeller, President James Frommeyer, Consultant

Howard Rosenthal, Staff Vice President of Engineering, David Sarnoff Research Center 
Table E-1. COMPANIES AND INDIVIDUALS PARTICIPATING IN STUDY (concluded)

POTENTIAL PRODUCERS (cont'd)

Varian Associates

Mobil Tyco Solar Energy Company

SES, Inc.

Photon Power, Inc.
John Heldack, Vice President Corporate Development and Public Affairs

Edward Barlow, Vice President, Research and Development

Ron Bell, Director, Solid State Laboratory

Henri Maget, Program Manager, Corporate Solar Energy Programs

Jim McNeil, President

A. I. Mlavsky, Executive Vice

President

Steve Dizio, President

Robert Johnson, Manager, Marketing

Guy Roderick, President

\section{E.3 FUTURE APPLICATIONS AND CUSTOMERS}

Current and potential producers are optimistic about future growth in the size of foreign markets. All but one of the 13 companies interviewed were confident that international markets will be the most important markets for photovoltaics through the mid-1980s. Several companies believed that international markets may dominate sales into the 1990s.

Expansion of international markets for existing applications will offer significant growth opportunities. Water pumping for both drinking and irrigation, remote general power systems (substituting for gas and diesel generators), and water desalination are believed to be the most promising applications. Educational television systems and refrigeration also show some promise. All of these applications have been identified previously in photovoltaic market studies. At present, photovoltaic companies do not expect yet-to-bedefined applications to lead to growth in international sales.

Most companies categorized markets for foreign sales into three general groups. The first consists of industrialized nations, such as European countries, that will have characteristics similar to U.S markets. Several companies presently are marketing in these countries and anticipate some growth in industrialized markets. Australia, for example, has already proved to be an attractive market. The large rural areas of Australia and the financial resources available to purchase photovoltaic systems make Australia a good future market.

The second market group is made up of developing countries with access to monetary resources for financing photovoltaic systems. The oil-rich countries in the Middle East are an example of this group. These countries have needs for power typical of developing 


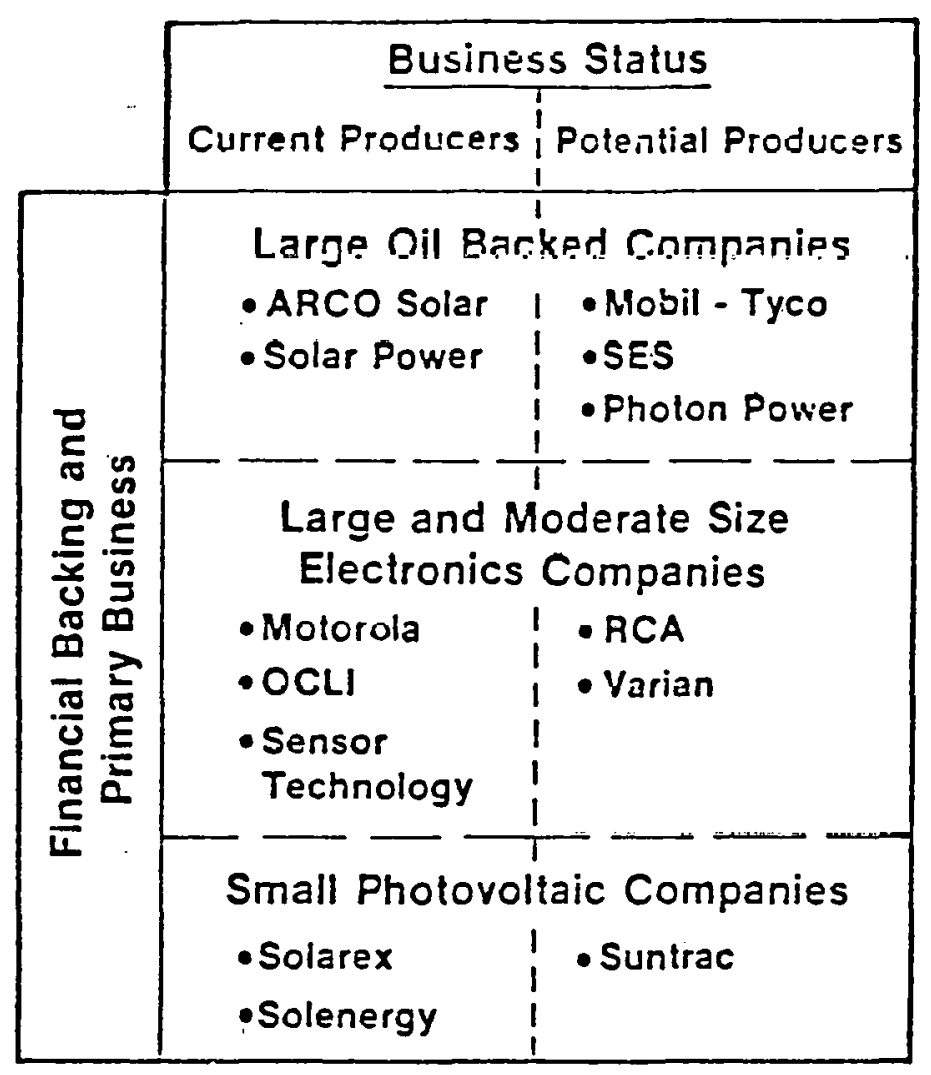

Higure $\bar{E}$-1. CATEGORIZATION OF COMPANIES INTER VIEWED 
countries, but have only limited electric utility systems for irrigation, potable water, refrigeration, and general power. Countries in this group will initiate substantial development efforts over the next decade that will provide for these and other needs. Projects will be funded with their own resources or with private financing. Photovoltaics could be used in many of these projects.

Poorer developing countries make up the third market group. The need for electric power in these countries is great. Photovoltaics could be well suited to meet many of these needs. The delta regions of Africa, for example, might benefit from extensive irrigation supplied by small-scale photovoltaic pumps. However, it is unlikely that these countries will have the resources to fund many projects. World development institutions such as the World Bank, the U.S. Agency for International Development, and other aidgiving nations and agencies would need to support these projects.

The customers for photovoltaic systems among these market groups are expected to vary. Foreign governments will be the most likely customers among the financially selfsufficient developing countries. Ministries of development in agriculture and electrification may make the majority of decisions concerning the selection of types of projects and power supply. For the poorer developing countries, ministries of government as well as officials in institutions that finance development programs will share decision-making power. In the industrialized countries, private purchasers, utilities, and government officials are all likely customers. U.S. photovoltaic companies may take a variety of approaches to selling in these markets.

\section{E.4 OBSTACLES TO INTERNATIONAL SALES}

Seven principal obstacles to U.S companies increasing their photovoltaic sales in international markets were identified. These are listed in Table E-2. Several of these obstacles were mentioned repeatedly by companies interviewed.

One obstacle described by many companies is that photovoltaic systems are too expensive for foreign applications and markets. Reductions in photovoltaic system prices would improve the outlook for international sales. All of the companies interviewed were confident that optimal photovoltaic system prices could be achieved, at least to the extent that their cost-effectiveness in several applications for international markets would be improved. Reductions in photovoltaic module prices are anticipated, as well as balance-of-system costs, through standardization of components and systems. Transportation costs, however, could make the cost of complete systems shipped from the United States prohibitive. One company felt that foreign purchasers were not particularly price sensitive and that other obstacles would prove more significant than price.

A second obstacle is the lack of funds to pay for photovoltaic systems. This obstacle is particularly important in the poorer developing countries. Some companies fear that current optimism about foreign markets may be based on simplistic assessments of needs. Limitations in funds could greatly reduce actual demand.

Several companies are concerned about the costs of effectively marketing photovoltaic systems in international markets. Current foreign markets are highly fragmented; sales to these markets require substantial effort. Actual sales are mostly for single, small, systems, making the marketing-costs-per-sale substantial. The actual purchasers in many foreign markets are also difficult to identify. Government officials or officials of 
development institutions will of ten be the decision makers. Finding the appropriate official adds to marketing costs.

Two obstacles stem from poor information about photovoltaic system capabilities and potential markets. On the purchaser side, potential users of photovoltaic systems know little about photovoltaic applications, system availability and performance, specific suppliers, or cost. Before international markets expand greatly, the public needs to become more familiar with photovoltaics. Suppliers are also poorly informed on potential markets, perhaps because market experience to date is limited. Market studies have yet to define the characteristics of markets at a level of detail sufficient for companies to develop detailed marketing plans. Even companies with more extensive experience are uncertain about the ultimate potential of several markets and applications. While some level of uncertainty is inevitable, a better understanding of the international market would motivate companies to pursue more aggressive marketing plans.

Related to the obstacles of insufficient information on the part of both users and suppliers is that more needs to be known about how photovoltaic systems work in specific applications. Several suppliers felt that international sales would not expand rapidly until more users have gained experience with photovoltaic systems. Building systems would also help companies improve system designs.

The last obstacle was identified by only one company. That company felt that the United States has a poor reputation in many developing countries where the influx of American industry is associated with political control. This image problem may make many countries hesitant to encourage the expansion of U.S. photovoltaic sales.

\title{
Table E-2. OBSTACLES TO INTERNATIONAL SALES
}

\author{
High Price of Photovoltaic Systems \\ T,ar:k of Financing In High-Need Areas \\ Hlyl! fousts of Marketing \\ Inw Ilser A wareness \\ Lack of Supplier Information on Markets \\ Limited Systems Experience \\ Poor U.S. Government Reputation In Some Markets
}

\section{E.5 BUSINESS AND MARKETING ARRANGEMENTS}

Photovoltaic companies use a variety of approaches to sell in international markets. All seven of the current producers interviewed make some sales through direct contact with foreign purchasers. Companies that are subsidiaries or affiliates of large, multinational corporations take advantage of the marketing abilities of their parent corporations and affiliate companies. Arrangements with local distributors in foreign countries are also made by photovoltaic companies. Some companies have formed joint ventures with foreign companies that sell electronic or other related equipment or that will produce photovoltaic cells. Joint ventures with French electronics and original equipment manufacturers (OEM) of relevant equipment (e.g., pumps) have been initiated by several companies. These arrangements are intended in part to take advantage of French marketing strength in Africa, particularly through French development programs.

These various business arrangements are expected to continue as international markets expand. The need for local distributors will increase and photovoltaic companies will 
continue to team with original equipment manufacturers to deter marketing costs. Small companies, especially, will rely on OEM marketing abilities. Systems companies with marketing positions in foreign countries will become another sales avenue.

Several companies see an evolution in marketing photovoltaics internationally, from initial exporting of complete U.S. systems, to exporting photovoltaic modules, to exporting photovoltaic production facilities. This evolution will occur as international markets expand. It will become more economical to use indigenous capabilities to assemble the components of complete systems. This approach is already common today. For example, a French pump has frequently been teamed with a U.S.-manufactured photovoltaic module. User countries are also likely to want to play a larger role in putting together systems. This larger role may be essential to meet service and installation requirements. As photovoltaic sales increase, many countries will desire to manufacture modules in their own country. At this point, the role of U.S. companies may be limited to licensing production facilities or to building and operating plants outside the United States.

Companies that foresee this trend felt strongly that it is unrealistic to anticipate largescale exports of complete systems. Not to move in the direction of exporting modules and production facilities would diminish the competitive position of U.S. photovoltaic companies. Therefore, a systems marketing approach would still be necessary. Most companies believe that the market for photovoltaics will be a systems market. But, the extent to which components of these systems will be manufactured exclusively in the United States will be reduced. The trend will be toward greater reliance on systems and manufacturing capabilities in user countries.

\section{E.6 INTERNATIONAL COMPETITION}

Two factors give some international competitors a possible advantage in photovoltaic markets: marketing ability and government marketing assistance. Historically, the United States has not been particularly effective at selling products in international markets. France and Japan have proven to be more successful in foreign markets. The French have been particularly strong in some developing regions, such as in Africa where early markets for photovoltaics have been supported through French development projects. Japan has shown a strong ability to implement technology developed elsewhere, to produce products cheaply, and to sell them throughout the world, especially in Asia.

As for government support, governments are known to support export activities of their own companies more aggressively. The French, according to two companies, encourage competing French companies to concentrate their marketing in separate regions, thereby reducing competition and marketing costs. Foreign governments were also said to support sales activities and marketing exhibits of their photovoltaic companies. Details on the extent or origins of this support were not provided.

Several countries are supporting photovoltaic technology development and production. None of the companies interviewed, however, were particularly concerned that other countries would gain a preeminence in the technology area. Germany and Japan could develop a competitive product, as could others. But the U.S. position in the technology area appears to be strong.

Although several companies felt that foreign companies could develop a marketing advantage in photovoltaics, no company believed that this advantage could not be challenged. Even in French-supported development projects in Africa, U.S. companies are 
successfully selling photovoltaics through cooperative arrangements with French suppliers. Marketing support offered to photovoltaic companies by other governments appears to be stronger than that of the United States in this early stage of market development. This is the reason why the French have been successful in Africa with photovoltaics, for example. But companies interviewed expect to compete in the future. They would like to see increased support by the U.S. government to offset any advantage that their competition might enjoy.

\section{E.7 ROLE OP THE U.S. GOVERNMENT}

Table E-3 lists the government actions recommended by the companies interviewed. Twelve of the thirteen companies believe that photovoltaic demonstration projects relevant to international applications would be an effective way for the U.S. government to facilitate the development of international markets. A few companies think that it is not essential that these projects be conducted outside the United States, so long as they are oriented toward international applications. However, demonstrations in foreign countries would be more helpful to potential users and producers.

Companies are concerned that demonstrations of international applications be conducted properly. Of particular concern is the choice of applications. In the past, demonstrations with little relevance to international markets have been funded. These projects are of ten too large; most sales of photovoltaic systems will be smaller. The U.S.-Saudi Arabia Soleras program's 350-kW village power system, outside of Riyadh, is an example of a system much larger than any likely to be sold commercially. Demonstration systems also tend to be overdesigned. Projects more similar to those in possible commercial markets should be funded as demonstrations. Administrative requirements of an international demonstration program also need to be minimized. A demonstration program should not have so much government involvement and control that industry learns little about the market. Industry should be given the flexibility to learn from market conditions and respond to them, and, with the help of users, to select appropriate projects.

Information dissemination is a second area in which several companies suggested the U.S. government could help foreign sales. One of the major obstacles to greater foreign sales is lack of awareness on the part of foreign purchasers. One company stated that through an aggressive information dissemination effort, the government could introduce buyers to sellers. Individuals in charge of development projects should be the target of one aspect of an information program. U.S. agency representatives (Embassies, AID, etc.) could be used in information dissemination efforts. Some companies, however, were concerned that these representatives might not devote sufficient attention to photovoltaics in the midst of numerous other responsibilities.

\section{Table E-3. RECOMMENDED GOVERNMENT ACTIONS}

Demonstrations in International Markets

Information Dissemination to Potential Purchasers

Information Dissemination on Markets to Suppliers

Support for Trade Fair Participation

Support for Marketing

Provide Accessible Description of U.S. Programs

Federally funded market studies were another form of support suggested. Companies disagreed on the value of publicly available market studies; about half felt they are help- 
ful. Other companies stated that studies have been too general to be of much use. However, if country-specific studies of sufficient detail that examine sales mechanisms, financing, government regulation, and other relevant market factors were conducted, these studies could be helpful. No company interviewed believed that public studies could substitute for their own market research. However, they could offer a starting point. Small businesses, especially, could benefit from well planned, public market studies.

International trade fairs were thought by about half the companies interviewed to be a good approach to information dissemination. One of the problems with trade fairs is that they rarely lead to actual sales for a participating company. Instead, they tend to raise general awareness about photovoltaics, which of ten makes the costs of sending and staffing an exhibit more than they are worth to a participating company. Federal support for trade fair participation would make U.S. companies' participation more feasible, and could reduce companies' concerns that the benefits of participation are only to the industry in general.

Several other government actions were suggested by individual companies. One company thought that U.S. manufacturers should be trained in effective exporting techniques. Another suggested that loans for systems bought by developing countries should be guaranteed. One company recommended that marketing costs for international sales efforts on the part of small businesses could be paid by the government.

Still another company stated that no matter what the government role, there is a need to describe clearly to U.S. industry how available programs work and could be useful. 'Currently, U.S. activities are very scattered. It is nearly impossible for companies to identify sources of help and information needed to market photovoltaics internationally. A directory of federal programs, which is periodically updated, could be valuable. 


\section{SE리}


APPENDIX F

POLICY STRATEGIES POR THE INTERNATIONAL MARKETING OF U.S. PHOTOVOLTAICS

\author{
Prepared by \\ IIT Research Institute \\ for \\ Jet Propulsion Laboratory
}




\section{THIS PAGE \\ WAS INTENTIONALLY \\ LEFT BLANK}


EXECUTIVE SUMMARY

POLICY STRATEGIES FOR

THE INTERNATIONAL MARKETING

OF U.S. PHOTOVOLTAICS

August 1979

Prepared for:

Jet Propulsion Laboratory

California Institute of Technology

4800 Oak Grove Drive

Pasadena, California 91103

Prepared by:

IIT Research Institute

10 West 35 th Street

Chicago, Illinois 60616

JPL Contract No. 955463

IITRI Project No. J6502

(Formerly C6454) 
This work was performed for the Jet Propulsion Laboratory, C.alifornia Institute of Technology, under NASA contract, for the Dcpartment of Energy. For copies in this report contact Mr: Robert S. Levi, Manager, Technology Transfer and Market Research Section, IIT Research Institute. (312/567-4609). 
POLICY STRATEGIES FOR THE INTERNATIONAL

MARKETING OF U.S. PHOTOVOLTAICS

\section{EXECUTIVE SUMMARY}

\section{Preface}

The increased world demand for energy, rising oil prices, and uncertainties in supply have stimulated an increased inclination of developed and lesser developed countries (LDCs) toward energy self-sufficiency. It is apparent that such alternative energy sources as solar energy, photovoltaics (PV) in particular, represent.viable opportunities today in the international marketplace, especially the LDCs. The long-term business outlook for sales of alternative energy products and systems is thus extremely favorable. At the same time it is important to recognize that current risks are high, as a result of uncertainties affecting energy technologies, markets, etc.

This indicates that every reasonable coordinated effort should be made by the U.S. Government and industry to counter the initial risks by accelerating the international market development of such promising energy technologies as photovoltaics. The Photovoltaic Act of 1978 specifies that the Department of Energy (DOE) shall develop a plan "for demonstrating applications of solar PV energy systems and facilitating their widespread use in other nations." This plan, which will be completed by November, 1979, is expected to support a program that will provide near- and mid-term demands for U.S. photovoltaic products, aid in market development, and assist in meeting the electric energy requirements of developing countries.

The objective of the IIT Research Institute (IITRI) study was to provide an inpul to this plan by developing and doćmenting policy strategies for the international marketing of U.S. photovoltaic systems and products, with particular emphasis on the 1980-1990 timeframe. Several key issues were considered in the course of the study which impact the implementation of photovoltaic policy strategy options by government and industry. These issues include the following: the qualitative impact on foreign sales by U.S. manufacturers, the possible barriers to implementation of the options, and the appropriate posture, legislation, and action required by the U.S. Government and its agencies. The IITRI study was designed to develop creative and novel approaches that would facilitate the export of U.S. photovoltaic products and systems abroad as quickly and effectively as practicable. 
The study objective was accomplished by integrating the ideas and viewpoints of experts knowledgeable and experienced in the international marketing of high technology products into a policy strategics report. The experts were selected on the basis of their extensive individual contributions in industry as well as the consulting sector, relating to energy development and international marketing of high technology products and systems. Specific industrial experience of the experts is represented by their current and previous positions as: Director of Commercial Development and Planning for International Minerals and Chemicals; corporate market analyst for Ford Motor Company; Managing Director of International Harvester subsidiaries in New Zealand, Australia, and France; and industridl engineering, manufacturing and interlla liurial markcting manager for motonruld. Ilic. In addition, the experts represent a broad base of consulting experience including such positions as: President of Solar Energy Information Services (SEIS) and Solar Energy Business Consultants (SEBC); Assistant Director of the International Division of IIT Research Institute; United States Senior Advisor on Science and Technology to the United Nations; consultant to the U.S. Department of State; member of the Advisory Committee for the U.S. Department of Commerce and the East-West Trade Council; Director of IIT Research Institute; Senior Program Manager and Manager of Energy and Environmental Programs office of Battelle's Columbus Laboratories; member of the U.S. diplomatic service; and consultant to the World Bank on export of manufactured goods from developing countries.

There were three primary task elements directed toward the objective. They consisted of two workshop sessions held at IITRI in Chicago and an independent preparation of concept papers by the experts. This report summarizes both the individual and joint efforts of the expert panel in identifying, developing, and integrating viable government and industry options for the purpose of developing the international market for photovoltaics.

To support the implementation of the tasks, the latest available information was used to brief the panel regarding the current and expected future state of the photovoltaic technology, industry, applications, and markets. Important assumptions were made at the outset to permit the expert panel to develop policy option strategies which could be synchronized with the overall export plans and actions of the U.S. Government and the PV industry. The major assumptions and base line of information used by the experts are described below. 
An international market now exists for U:S.-made photovoltaic products and systems. The plan DOE will develop for the international marketing of photovoltaics is based on this assumption.

- It has been determined that PV products and systems are currentiy cost-competitive in foreign markets, particularly LDCs.

- PV products and systems will have major near-term potential for remote applications such as water pumping and village power.

- Significant PV market development in international markets is anticipated within the 1980-1990 timeframe.

- It is expected that increased production in response to a developing international demand for photovoltaics will have the benefit of reducing costs to allow advanced $P \dot{V}$ technology to ultimately become competitive in the U.S. market, and other grid-oriented markets, beginning in the late 1980 s.

As the international market for photovoltaics develops, the nature of the PV industry itself will change. It is expected that while photovoltaic products and systems are today primarily marketed by PV cell and/or system. firms, the core of international PV demand may be stimulated by end-use products such as pumps, appliances, etc., which incorporate photovoltaic components. Thus the original equipment manufacturers (OEMs) represent a key element in what will be considered the PV industry.

\section{Findings}

The IITRI study resulted in two forms of output. The concept papers of the experts represent individual perspectives on the task of developing an approach to the international marketing of J.S. photovoltaics. Secondly, the workshops at IITRI provided a significant level of information and detail regarding the formulation of an integrated set of policy strategies for penetrating the international PV market in the near-term. These two forms of output are described in the paragraphs which follow. 


\section{Individual Concept Papers}

The concept papers represent a diverse set of perspectives regarding the potential mechanisms and approaches which would be most useful and/or necessary to penetrate the international market for U.S. photovoltaics. The range of concepts is represented by the following summary descriptions: the development of a new product diffusion theory as applied to photovoltaics; the establishment of a U.S. international export company to provide for a coordinated, integrated U.S. thrust into the international PV marketplace; an emphasis on the market development of target countries which are politically-, socially-, energyappropriate for photovoltaic systems; and the development of strategy mechanisms which are phased to (1) analyze in detail the PV applications (i.e. market identification and analysis studies), (2) provide PV prototype development and testing targeted to countries and applications, and (3) provide PV production and marketing strategies which will quickly build a responsive supply-demand structure. All of the concept papers address the issues as to what the industry could/should do and what the U.S. Government could/should do to constructively foster the rapid development of a viable PV market structure to serve the energy needs of the international community and the LDCs in particular:

\section{Workshop Sessions and IITRI Analysis}

The results of the IITRI study represent the most promising policy strategy options, designed and integrated to provide the maximum positive impact on foreign PV product sales by U.S. firms. The results present several international marketing options, which are supplemented by several specific political/legislative actions and finance-related incentives that impact the successful implementation of the marketing options. Thus we have segmented our policy strategies and recommendations in the following manner:

International Marketing Options

- Market-Related Political/Legislative Actions

- Finance-Related Incentives 


\section{- International Marketing Options}

The international marketing options are oriented toward a new product adoption mechanism which focuses on (1) identifying and segmenting potential users/purchase-decision makers and (2) targeting promotional and market development efforts in order to generate awareness and interest, and stimulate trial, evaluation, and adoption. The options we have developed are defined as follows:

- Market Identification:

Determine those end-user countries and applications that would offer the quickest and most success.ful penetration for PV product/systems worldwide.

- Market Development:

Provide market development support for individual firms in those countries where selected PV applications appear most promising.

- Market Awareness (outside the U.S.):

Design and implement a comprehensive market awareness program which will enhance an early and rapid development of international market potential.

- Market Awareness (inside the U:S.):

Organize a series of tours for representatives from potential PV end-user countries to visit U.S. PV installations.

- Local Partnerships:

Identify and establish local partnerships between the U.S. PV industry and appropriate organizations in each target country in order to gain quick entry to in-place business relationships and distribution and service systems.

\section{- Field Demonstrations:}

Develop a program of field demonstrations in several target countries which will show prospective purchasers and users the merits and benefits of PV products/systems in their own environment.

Each of the above options is presented on pages 7 through 19 in terms of:

- the background (justification) for proposing the option

- the action plan (mechanisms) for implementing the option, including possible political/legislative action 
- the results anticipated from implementation of the option

- the potential advantages and disadvantages which the option represents in terms of the overall international PV plan.

The marketing options are not mutually exclusive, but rather represent the spectrum of involvement by government which would be most constructive to the future viability of the PV industry and the international PV plan. It is crucial to the success of the PV plan that the government act decisively, swiftly, and in a straightforward, integrated fashion to achieve the objective of significantly penetrating the international PV market in the near-term. If immediate steps are not taken to deve 10 p the international PV market, significaril delays will occur in the nverall PV program which will hinder the acceplance of photovoltaics as a viable solar energy option. In particular, the identification and characterization of target applications, markets, and countries repre.. sents the key initial task which must be accomplished as soon as practicable to permit efficient and well-focused implementation of subsequent marketing activities.

Once initial findings have been obtained through market identification efforts, the subsequent options of an integrated PV plan can proceed concurrently, supported by appropriate actions from government and industry. It is critical to the success of the plan that there by substantial industry-government interaction, as well as industry involvement and feedback. Government. support should not be directed toward creating excessive artificial derland, since that will not reduce the long term risks of PV market development, only defer them. The government should focus resources and incentives on the development of a strong and dynamic industry based on photovoltaic technology, in order to create a stable, long-term PV supply and demand market structure. 
INTERNATIONAL MARKETING OPTION: Market Identification

OPTION STATEMENT:

Determine those end-user countries and applications that would offer the quickest and most successful penetration for PV products/systems worldwide.

BACKGROUND:

There are many potential PV applications which can be marketed in a vast number of appropriate user countries. It is apparent, however, that many of these markets may be difficult to reach for various reasons: diffuse end-use markets, lack of ability to pay, unfavorable political environments, existing alternatives to photovoltaics which may represent more appropriate technology, minimal U.S. presence in the country. The PV industry, in order to effectively develop the market, requires detailed information regarding potential international markets as evidenced by the issues raised at the DOE Solar Export Opportunities Workshop, Atlanta, Georgia, 1979.

ACTION PLAN:

An ongoing identification and evaluation of international markets should be conducted by an independent private organization.

Funds for this work should be provided on a joint basis by the U.S. Government and PV Industry.

- $50 \%$ funding by Department of Commerce/Energy

- .50\% funding by PV Industry on a prorated basis (consortium)

Developed information will be provided initially to subscribing companies only, with public release delayed for a predetermined period of time.

Continual updating of information will be given to all participants.

A "Board of Directors (Advisors)" comprised of industry and government representatives will act as a Steering Committee:

- To focus the efforts to usable data and results

- To orient the industry towards the international market

This program will represent a screening mechanism for PV international market development in order to:

- Identify those countries which offer potential for photovoltaics:

- Solar plentiful countries

- Countries where sales of U.S. products and technologies are currently strong

- Energy poor countries that are:

- Striving for agricultural self-sufficiency

- Currently recipients of A.I.D.

- Able to "pay"

- Select applications that best suit the need of the target countries. 
INTERNATIONAL MARKETING OPTION: Market Identification (continued)

\section{ANTICIPATED RESUI_TS:}

Provide complete information to the industry on potential international markets and countries by application:

- Product/system applications

- Estimated potential sales

- Price elasticity and economics

- Nature of competition

- User government attitudes (priorities, technology acceptance, solar position, existing development projects, etc.)

- Customer profiles (decision makers, end-users, infrastructure)

- Putential channels of distributiun (lucal partners)

- Desire and ability to manufacture/insta11/service

- Ability to pay for purchases

- Relative effect on the quality of life

- To selectively segment the potential market and obtain continuous feedback of changing requirements and applications.

\section{ADVANTAGES AND DISADVANTAGES}

\section{ADVANTAGES}

Information will be provided on international markets that normally would be difficult and expensive to obtain by an individual company.

The feedback aspect of this program will provide continuous information on market needs, developments and changes.

The program will provide necessary data that permits quick market penetration and development.

Joint market identification efforts will encourage continued industry involvement throughout the program.

\section{DISADVANTAGES}

There may be legal restrictions that prevent controlling (access to) the information and that prohibit use of government funds to benefit individual companies in the consortium.

Unless this information is developed quickly, the PV industry will lack a valuable resource that will allow for timely and significant action to be taken in developing selected international markets. 


\section{OPTION STATEMENT:}

Provide market development support for individual firms in those countries where selected PV applications appear most promising.

\section{BACKGROUND:}

As market information is obtained it is important to act on this information by marketing selected PV products and systems in target countries. There are firms in the PV industry which have identified or eventually will identify the applications, countries, and markets appropriate for PV products and systems. But the firms in general lack the resources and capabilities to quickly develop the international market. This indicates the value of formulating an assistance program which would be directed toward helping PV firms develop markets abroad.

\section{ACTION PLAN:}

Firms that lack sufficient resources to develop international markets on their own cuuld request financial assistance from the U.S. Government.

The Government (Department of Commerce/Energy) should issue "product opportunity notice(s)" requesting proposals by individual firms for assistance in market development.

The companies requesting assistance must submit a non-confidential business strategy for the application, market, and country to be developed.

Funding could be awarded on a cost-sharing basis:

- Government funds, but using applicant company manpower

- Development costs could be repaid partially to the Government from ultimate sales of products.

Government funding could be used for typical market development costs:

- Salaries (plus related overhead)

- Engineering design

- Sales literature

- Travel

Highly detailed information will be obtained by visits to each selected country:

- Market segments

- Decision-makers

- Energy programs and plans

- Current U.S. presence

- Channels of distribution

- Costs and economics of doing business

Any information resulting from this assistance program should be kept confidential for some period of time.

The results of this option will be to develop the market and achieve sales in selected countries. 
INTERNATIONAL MARKETING OPTION: Market Development (continued)

ANTICIPATED RESULTS:

To establish on a selective basis first-hand contacts in potential markets for the U.S. PV industry

The firm will experience in-country presence and will establish contacts and long-term relationships that ultimately should result in sales:

- Determine the decision makers

- Establish local partnerships

- Assess the market potential

- User needs

- Product/system applications

- Ecunumics/price

- Determine methods of payment or credit

This market development option will establish a U.S. Guvermulnl pusilion of funding and in-country liaison, and will allow U.S. companies to experience and undertake the market development themselves.

ADVANTAGES AND DISADVANTAGES

ADVANTAGES

Creates the opportunity for rapid market development that otherwise would not take place.

Allows early and continuous dominance by U.S. firms in international markets.

\section{DISADVANTAGES}

Program would not be adopted by all companies in the PV industry.

- Companies have capabilities and/or ties to do the market development themselves.

- There may be concern that the experience gained by a firm might be used by a competitor.

- Criticism may be raised that the U.S. Government involvement could limit free competition among U.S. PV firms in particular selected country/markets. 
INTERNATIONAL MARKETING OPTIONS: Market Awareness (Outside U.S.)

OPTION STATEMENT:

Design and implement a comprehensive market awareness program which will enhance an early and rapid development of international market potential.

\section{BACKGROUND}

The maximum return on market development efforts is gained by generating market awareness. It is therefore appropriate to develop a market awareness program to assure that all key decision makers and adopters are made cognizant of the value which PVs can represent to them in terms of: user benefits, energy self-sufficiency, agricultural improvements, and improved standard of living. It is imperative that the U.S. PV industry have a full appreciation of the country-specific values, business techniques and mechanisms, political attitudes, and purchase decision variables. When properly phased, a market awareness program will serve as an adjunct and support to market development efforts.

\section{ACTION PLAN}

A market awareness program should represent a multiple thrust effort to support ongoing industry market development activities.

While the U.S. Government should manage this awareness program, it is imperative that industry representatives play an active role in implementing the program.

This program should be federally funded jointly by the U.S. Departments of Commerce and Energy with support from the Department of State.

Not only should the industry participate in designing the program, but members should also be involved in the market awareness activities in the selected countries.

A 'PV' market awareness team should be coordinated by DOE and be comprised of government specialists and industry representatives:

Government Specialists

- Energy/Photovoltaics

- Diplomatic

- Commercial

- Agricultural

- Financial
Industry Representatives

- Key Management

- Marketing

- Product

- Engineering

- Communications/Advertising

Industry representaives should alternate to allow the widest industry involvement.

The PV Market Awareness Team would conduct international circuits through target countries to reach key decision makers and create awareness about photovoltaics and its practical value.

The Government should reimburse the industry representatives' expenses. 
INTERNATIONAL MARKETING OPTIONS: Market Awareness (Outside U.S.) (continued) ACTION PLAN (continued)

The awareness program should provide information regarding U.S. photovoltaic products/systems to key decision makers at all levels in each target country:

- Foreign Government officials (energy, finance, agriculture, planning)

- Universities

- Business leaders

- Potential regional users

A mobile information package should be organized which will support the efforts of the PV awareness team:

- Seminars (technical, economic)

- Literature

- Portable working models

- Mass media material (video tapes, press releases)

The market awareness team should interact with U.S. personnel in foreign countries:

- Embassy officials

- Other U.S. nationals (exchange professors, business people in foreign subsidiaries, A.I.D. and ACTION personnel, etc.)

ANTICIPATED RESULTS:

Generate awareness and stimulate trial among key foreign decision makers and adopters for U.S. products/systems:

- Costs

- Benefits

- Availability

Create a two-way exchange of information to assist U.S. suppliers in following-up on potential sales opportunities, as well as to assist interested foreign decision-makers and adopters in identifying sources of $\mathrm{PV}$ product/system supply.

Provide leads for individual U.S. firms to establish local partnerships and distribution mechanisms.

Provide feedback to the U.S. PV industry regarding the current and expected needs of target countries, as well as their ability and willingness to adopt photovoltaics. 
INTERNATIONAL MARKETING OPTIONS: Market Awareness (Outside U.S. ) (continued) ADVANTAGES AND DISADVANTAGES

ADVANTAGES

Provides an organized and well-targeted support to ongoing market development efforts of individual firms.

Sets the stage for subsequent demonstration and sales efforts and contributes to an awareness of the capabilities of U.S. suppliers.

\section{DISADVANTAGES}

Could provide fallout assistance to foreign competition through promotion of photovoltaics as a whole.

If not timed properly to coincide with the availability of the products and systems, the awareness program could affect the credibility of U.S. suppliers' ability to deliver. 
INTERNATIONAL MARKETING OPTION: Market Awareness (Inside U.S.)

OPTION STATEMENT:

Organize a series of tours for representatives from potential PV end-user countries to visit U.S. PV installations.

BACKGROUND:

An additional international market awareness effort would be appropriate to stimulate interest, commitment, and trial among decision makers and adopters. It is not only important for interested decision makers and adopters to be aware of the advantages and availability of U.S. PV products and systems, but also to personally view the operation of in-place systems. Aside from a general portable working model used by the PV awareness team outside the U.S., it is crucial in generating sales that decision makers observe applicable products and systems in operation inside the U.S. which could serve their specific needs.

ACTION PLAN:

The Department of Energy in conjunction with the PV industry should develop several itineraries of selected PV installations in the U.S.

The itineraries should be designed toward the specific needs of the foreign visitors.

These on-site visits will provide first-hand knowledge of the production and operation of PV systems.

These tours should be well-publicized, internationally, to reach the broadest cross-section of potential decision makers, change agents, and partners:

- Government representatives

- Business leaders

- Potential dealers

- University associates

- Others

The purpose of this program is to enable decision makers to be directed toward selected, appropriate application installations and companies that are most suited to their interests and needs.

In addition, information can be supplied to visitors concerning PV industry manufacturers' locations for the purpose of future contact.

ANTICIPATED RESULTS:

Key to this program will be the opportunity for potential decision-makers and partners to see the U.S. PV industry products in operation as

they relate to applications in their countries. 
INTERNATIONAL MARKETING OPTION: Market Awareness (Inside U.S.) (continued)

ANTICIPATED RESULTS: (continued)

Working relationships can be developed that will provide:

- Early feedback regarding the unique needs of each customer

- Informal communication between buyer and seller

- Good will toward the U.S. PV industry on the part of potential foreign buyers.

- Advantages over foreign competitors for U.S. firms entering target countries to make sales

- Contacts within the government and business hierarchies which will ease any subsequent marketing difficulties that might evolve

Generate serious interest which will lead to commitments and trial. A strong purchaser/user identification of U.S. firms with the concept of PV product/systems as an energy alternative.

ADVANTAGES AND DISADVANTAGES:

ADVANTAGES

There are minimal costs associated with this program for both the U.S. Government and the PV industry:

- Government involvement would be a focusing, publicity and coordination effort.

- Industry costs would be normal market development expenditures.

The program enables the U.S. PV industry to establish credibility:

- Manufacturing and engineering skills

- Demonstrated products/systems

- Visibility, image ana reputation.

Potential foreign partners and dealers can develop and strengthen working relaliunships with U.S. suppliers.

DISADVANTAGES

Foreign competitors can learn of U.S. PV activities from post-trip discussion with visitors. 
INTERNATIONAL MARKETING OPTION: Local Partnerships

OPTION STATEMENT:

Identify and establish local partnerships between the U.S. PV industry and appropriate organizations in each target country in order to gain quick entry to in-place business relationships and distribution and service systems.

\section{BACKGROUND:}

Quick and effective international market development depends on the utilization of existing infrastructures within target countries. Appropriate local manufacturing capabilities, materials availability, and channels for distribution, installation and service are key elements in gaining entry and penetrating the market. Success in marketing products abroad is dependent on a market strategy which is differentiated by the specific mechanisms and barriers in doing business within each target country. With the PV industry in its infancy, with no strong domestic U.S. distributor network, and with a major market emerging first internationally, it is crucial to quick market development to tie in to appropriate existing manufacturing/distribution/service arrangements in each target country.

ACTION PLAN:

As a result of local target country contacts established through market identification, development, and awareness efforts, the PV industry, with assistance from the U.S. Government, should solidify and expand countryspecific working relationships:

- Materials suppliers

- Manufacturing/Assembly

- Déder's

- Service organizations

- Research Institutes/Universities

- U.S. subsidiaries

The U.S. Government Department of Commerce should provide a list of U.S. firms doing business in each target country to encourage the possibility of 'piggybacking', tying in with an established U.S. firm's channels of distribution and/or service.

The U.S. Covernment should offer local partnership development grants to promote financial incentives and encourage a mutual commitment between U.S. PV firms and local target country firms:

- Local product development

- Local prototype trial

- Local manufacturing and/or assembly plant equipment

- Local field service training, service equipment, and vehicle support

- Training of local manufacturing/assembly personnel in the U.S. 
INTERNATIONAL MARKETION OPTION: Loca 1 Partnerships (continued)

ACTION PLAN (continued)

The grants should be tied to specific market development strategies and to a predetermined schedule, and should be available to any qualified U.S. firm.

When available and applicable for a target country, U.S. grants could be matched or supplemented by the government of the country to encourage its industry's participation and subsequent contribution to economic development.

Local partnership arrangements do not preclude the retention of proprietary technology/skills/information by the U.S. partner firm.

Technical licenses should be granted to the local partner for the use of trademarks; know-how, and that portion of PV systems technology which would be appropriate to in-country manufacture.

\section{ANTICIPATED RESULTS:}

Develops a healthy marketing, distribution, and servicing structure for operating within the country over an extended period of time.

Taps materials supply/manufacturing/distribution/service within each country to provide access to and stimulation of primary demand.

Permits an early cost-competitive position viz.a viz. the competition in key multi-country regions which represent the core of the international photovoltaic market.

\section{ADVANTAGES AND DISADVANTAGES:}

\section{ADVANTAGES:}

Establishment of local partnerships can effectively preempt future competitive presence by foreign PV firms within a target country.

Assembly by local firm desirable in avoiding import duties/quotas on PV products/systems providing a competitive edge.

Contributes to the economic and social advancement of developing countries through employment of local resources and reduction in required foreign exchange.

Encourages international scientific and technical cooperation through joint development and demonstration projects.

Close relationship between the U.S. and foreign partners provides convenient and reliable country-specific feedback regarding market needs and trends.

Allows access to existing distribution networks in target markets.

\section{DISADVANTAGES}

Implementation of plan may lead to difficulties in maintaining control of proprietary information.

There may be a limited number of appropriate local firms in each country willing and/or able to qualify for partnership with all interested U.S. firms.

Success of this option may preclude future entry by competing U.S. firms. 
INTERNATIONAL MARKETING OPTION: Field Demonstrations

OPTION STATEMENT:

Develop a program of field demonstrations in several target countries. which will show prospective purchasers and users the merits and benefits of PV products/systems in their own environment.

BACKGROUND:

For purposes of this report we define field demonstrations to be PV units/ systems which are operating in normal end-user environments to substantiate performance in specific applications. Prior to a final purchase decision the potential purchaser should have the opportunity to observe first-hand in his own or a similar end-use application, an operating demonstration unit/system. This is important to assure that products/systems are designed and manufactured for and are able to operate in a specitic country's end-use environment for each identified application.

ACTION PLAN:

Field demonstrations represent a key aspect in the advancement of market development after awareness and interest in PV products/systems have been initiated.

Local partners/dealers should be utilized to identify key potential users or early adopters who would provide the greatest impact in a region for field demonstration projects.

Field demonstration units could be offered to selected users by the suppliers on a limited trial basis with the option to purchase.

Through grants issued by the U.S. or local government, universities and research institutions could purchase field demonstration units and operate them in cooperation with a local village/farmer/cooperative.

Universities, research organizations, or individual users could be allowed to "buy" PV units/systems in return for supplying performance data and for allowing potential buyers to observe the unit in operation.

Grants should be distributed in a manner which assures demonstration of the most appropriate applications for a qiven market environment/country/ timeframe.

To maximize the opportunity for an interested potential user to purchase a PV product/system, a mechanism could be developed, in cooperation with the local government, which permits the purchaser to offer local materials/ products as a means of reducing foreign exchange requirements - so that imbalance in trade is minimized to the target country (e.g., LDC).

While performance data should be derived from each field demonstration project, these PV units/systems must not be unproven experimental designs.

It is important that in the case of each field demonstration the supplier/ installer assures that the PV unit operates as effectively as possible to foster only a positive image of photovoltaics which can lead to

additional sales. 
INTERNATIONAL MARKETING OPTION: Field Demonstrations (continued)

ACTION PLAN (continued)

It is important that the projects selected for field demonstration be chosen on the basis of their social/cultural/political compatability with the needs of the target country.

Field demonstration installations should include an in-depth training and education program for the user, to assure proper maintenance and use.

Field demonstration units should represent the latest in commercially available PV products/systems in order to provide to the user the best economic advantage.

Any PV model systems installed in U.S. Embassy locales, while perhaps useful for preliminary promotional efforts, do not serve the same function as field demonstration units because they are not operated to exemp ify realistic end-use applications.

Until field demonstration units are established on-site in target countries, existing PV installations in the U.S. could demonstrate several end use applications to interested design makers as part of a market awareness program.

\section{ANTICIPATED RESULTS:}

Exposure of large number of potential purchasers to PV systems operating in applications important to them.

Establishment of visibility and credibility of U.S. PV firms within the target countries which represent substantial market potential.

Formation of an in-place mechanism distributed across key countries and applications which can be used to capture the core of the international market for photovoltaics.

ADVANTAGES AND DISADVANTAGES:

ADVANTAGES

Provides for on-going feedback on performance of installed systems to respond to user needs and improve product performance.

Serves as a natural mechanism for up-front training and education of local field installation and service personnel.

Actively brings photovoltaic products/systems to the heart of "grass-roots" demand for energy alternatives.

\section{DISADVANTAGES}

Increased visibility of PV systems could aid foreign PV firms in their marketing activities.

If suppliers fail to provide quality products/systems and establish a responsive service network, the field demonstrations will result in a negative image for the PV industry and inhibit future sales efforts. 


\section{- Market-Related Political/Legislative Actions}

There are several government initiatives, involving political and legislative actions coupled with financial incentives, which should be used to support the marketing options proposed in this report. It is important to optimize the type, level of support, and timing of government efforts in order to reduce photovoltaic export trade barriers, enhance the growth of the PV industry, and provide practical incentives for U.S. PV firms to enter and develop the international market. The major government initiatives which we have identified, in addition to those recommended within each marketing option development, are described below.

- An outrcach cducation prograili slivuld be developed and implemented by the Department of Commerce/Smal1 Business Aduinistration as a mechanism for creating awareness among small businesses and new firms (currently or potentially involved in photovoltaics) of specific government programs and activities oriented toward entering the export market. An active dissemination plan (rather than a passive one) should be developed to target the information to firms who could utilize it to initiate or expand export emphasis in photovoltaics.

- A coordinated liaison effort of the Departments of State and Energy should be carried out to ensure a close, active liaison between the U.S. Government and the purchasing countries; in addition, coordination should be developed with international organizations such as the UN, FAO, etc., specifically with respect to photovoltaics. The liaison personnel would encourage target countries to consider PVs as valuable tools to achieve their energy planning and/or dyricultural self-sufficiency ubjectives. The program would provide a formal means to negotiate the transfer of funds to foreign governments to aid individual buyers in financing purchases. 
- PV cell/collector products and PV systems should be assured general (non-controlled) export license-status (representing non-strategic, non-sensitive goods which do not significantly affect the national security) in order to minimize the export requirements/restrictions of the U.S. Government.

- The Robinson-Patman Act should by amended to permit the PV industry to sell parts or products at different prices in different markets as long as price is at least equal to costs plus some reasonable profit.

- Legislation should be proposed to establish a more specific interpretation of the Webb-Pomerene Act so that small and medium sized firms in the PV industry may utilize the advantages of cooperative trading activities without unnecessary concern over antitrust actions under the Sherman and Clayton Acts.

- Introduce legislation and conduct discussions with target countries to permit release of Soft Currency (PL480) funds to be used to enable purchasing/finance of PV products/ systems.

- Finance-Related Incentives

In addition to political/legislative actions, there are several supportive and supplementary finance-related incentives which can be taken by the government to assist PV firms in implementing various marketing-related options and political/legislative actions. This assistance includes grants, loans, giveaways, tax and other incentives, information gathering and distribution, and negotiation. The most appropriate sources of this assistance are expected to result from discussions between the U.S. PV industry, the U.S. Government, foreign governments, and foreign and/or U.S. partner firms. These financial and otherwise supportive thrusts should be targeted to two discrete stages of PV commercialization: start-up and on-going. The figure on the following page illustrates the types of relationships and forms of assistance which would be most beneficial in developing an integrated, efficient approach to penetrating the international market as we 11 as reducing the risks faced by the PV industry at this early stage of the market. 
FINANCE -RELATED INCENTIVES

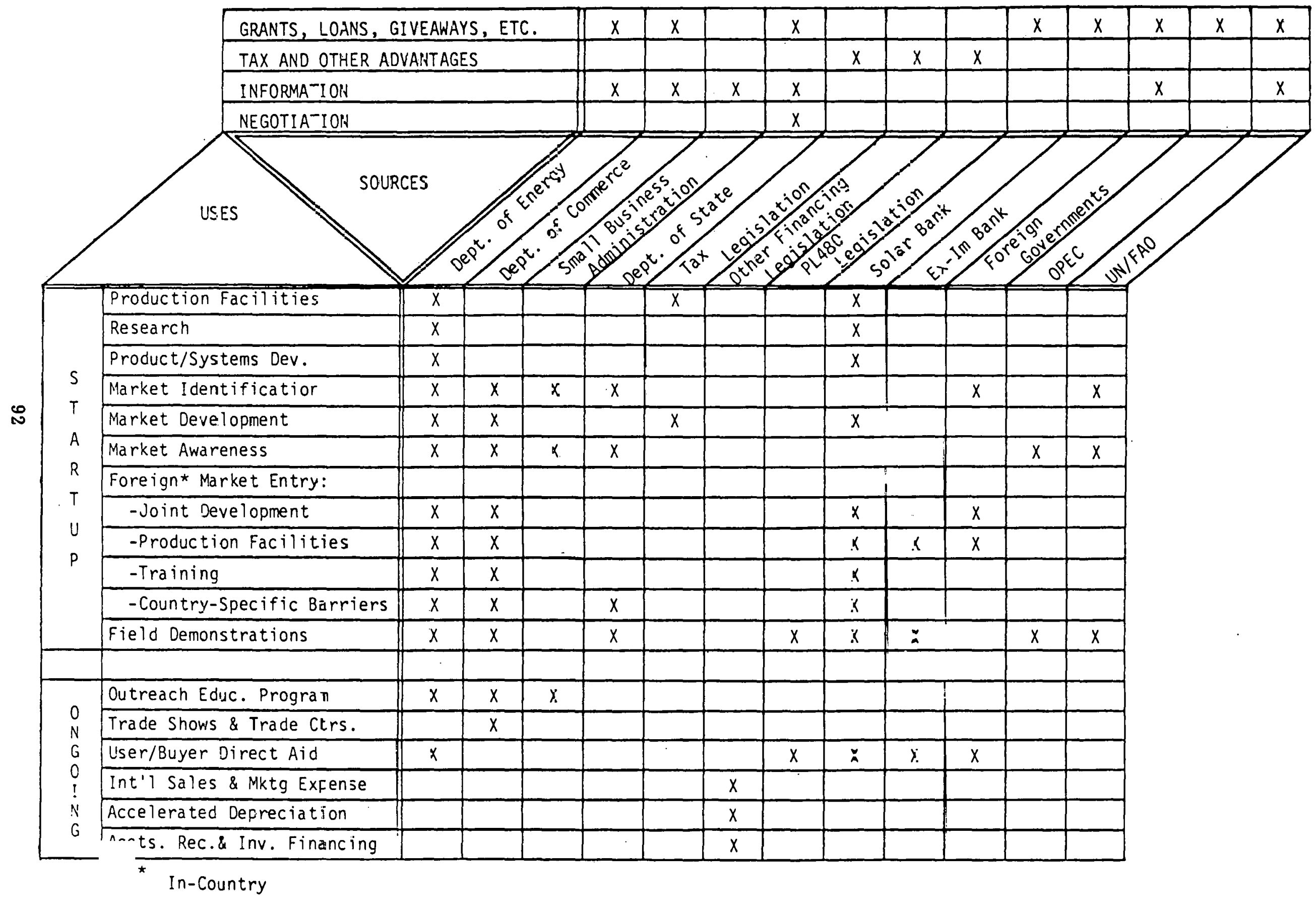


Summary Recommendations

The IITRI study recommendations are summarized below to demonstrate the range of actions which are necessary in order to consider the international PV plan as a serious effort to be accomplished within the decade of the 1980s:

- The international PV plan should be viewed by government and industry as a complex, highly interactive and reactive process which can only be implemented successfully over a time horizon substantially greater than that represented by any single point input of funds, manpower, etc.

- It is critical to the success of an international PV plan that there be substantial industry/government interaction, as well as industry involvement and feedback.

- Natural, proven high technology market development mechanisms should be utilized as a framework for government support and PV industry action.

- Government support should not create excessive artificial demand, since. that will not reduce the long term risks (real or perceived) of PV market development, but the government should focus resources and incentives on the development of a strong and dynamic PV-based industry--cell/module manufacturers, systems suppliers, and original equipment manufacturers.

- There should be an understanding on the part of all appropriate agencies and policy-making bodies of government that the objective of marketing photovoltaics internationally has three major thrust areas:

- specific,actionable marketing options

- market-related political/legislative actions

- supportive finance-related incentives

- It is crucial to the success of a PV plan that the government act decisively, swiftly, and in a straightforward, integrated fashion (in terms of political/legislative action and financial support) to achieve the objective of significantly penetrating the international PV market in the near term.

- It is felt that if immediate steps are not taken to develop the international PV market, significant delays will occur in the overall PV program which will hinder the acceptance of photovoltaics as a viable solar energy option. 
- Marketing options which have been presented in this report are not mutually exclusive, but rather represent the spectrum of involvement by government which could be most constructive to the future viability of the PV industry and the international PV plan.

- Six major marketing options have been presented in this report which provide a comprehensive plan for developing and penetrating in the near term the international market for photovoltaics:

- Market Identification:

Determine those end-user countries and applications that would offer the quickest and most successful penetration for PV products/systems worldwide,

- Market Develupment:

Provide market development support for individual firms in those countries where selected PV applications appear most promising,

- Market Awareness (Outside the U.S.): Design and implement a comprehensive market awareness program which will enhance an early and rapid development of international market potential,

- Market Awareness (Inside the U.S.): Organize a series of tours for representatives from potential PV end-user countries to visit U.S. PV installations,

- Local Partnerships:

Identify and establish local partnerships between the U.S. PV industry and appropriate organizations in each target country in order to ga in quick entry to in-place business relationships and distribution and service systems,

- Field Demonstrations:

Develop a program of field demonstrations in several target countries which will show prospective purchasers and users the merits and benefits of PV products/systems in their own environment. 
- The identification and characterization of target applications, markets, and countries represents the key initial task, which must be accomplished as soon as practicable to permit efficient and well-focused implementation of subsequent marketing activities.

- It is important that the marketing options be supported by appropriate actions from government and industry which will provide a phased progression from market identification to the remaining options.

. Once initial results have been obtained through market identification efforts, the subsequent options of an integrated PV plan should proceed concurrently.

- The Department of Energy should serve as the focal point for integration of all elements of a Government/PV industry plan in order to minimize duplication of effort and optimize the allocation of manpower and financial resources.

- The Department of Energy should be given clear lines of inter-agency leadership and coordination responsibility for implementing the international PV plan through a formal congressional and presidential mandate. 


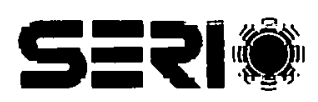




\section{APPENDIX G \\ IMPACT OF INTERNATIONAL FINANCIAL INSTITUTIONS ON MARKETS FOR SOLAR ENERGY SYSTEMS}

Prepared by

Strategies Unlimited 


\section{THIS PAGE WAS INTENTIONALLY LEFT BLANK}




\section{EXECUTIVE SUMMARY}

In support of the International Photovoltaic Program Plan being prepared for the U.S. Department of Energy by the Solar Energy Research Institute, Strategies Unlimited has conducted a study to assess the impact of international financial institutions on the markets for solar electric systems, with special emphasis on photovoltaic power systems. In this report, international financial institutions are assessed in the context of an overall review of the sources and uses of funds for economic development in the Third World. The origin of development funds is quantified, the channels through which funds reach the developing countries are examined, and the . economic sectors where funds are applied for country development are detailed.

The role of both public and private financial institutions in providing development funds that could be used for the purchase of photovol taic systems is examined. Policies and attitudes of bilateral and multilateral organizations toward solar programs are summarized. The project cycle for the development of programs that may use photovoltaics is described.

The emerging use of photovol taics in international markets has brought to industry attention the importance of international financial institutions to the future expansion of Third World markets. This study has been conducted to gain insight into the financial community as it will impact the growth of these photovol taic markets.

The methodology for this study is based on a classic top-down assessment of funds for the development of the Third World. By this methodology the magnitude of funds are measured at their source, the donor countries. Funds are then tracked as they pass through international financial institutions to the developing countries where they are applied to various projects and programs deemed appropriate for local development. The study identifies and prioritizes economic development activities in the Third World by:

- World geographic region

- Country per capita income class

- Economic sector class (agriculture/power/ electricity/other)

- Lending institution

Patterns and trends in lending are examined as they influence the future development of the solar electric market. 
The scope of this investigation is limited to the U.S. offices of the principal multilateral financial institutions, U.S. bilateral financial institutions, and the principal U.S. commercial banks. The study did not include U.S. government offices active in Official Development Assistance, such as AID.

Both primary and secondary information were used in the preparation of this report. Primary information included in-person interviews with decision makers at:

- Multilateral institutions

- World Bank

- Inter-American Development Bank

- International Monetaiy Fund

- Bilateral institution

- Eximhank

- U.S. international commercial banks

- Bank of America

- Chase Manhattan

- Citicorp

- Morgan Guaranty

- Manufacturers Hanover Corp.

- Regulatory institutions

- Federal Reserve

- Comptroller of the Currency

Interviews were conidurted in order to examine attitudes and perspectlves toward the solar market. Opinions of alternative government policies appropriate for assisting international export sales of photovoltaic or other solar energy systems were solicited. Secondary source information included a variety of reports from all the institutions interviewed as well as annual reports from development banks which were not interviewed. 


\subsection{SOURCES OF FUNDS FOR DEVELOPMENT}

To understand the impact of international financial institutions on the development of any market, one must first understand the existing patterns and levels of demand for funds flow to the developing world. Toward this objective, a review of the sources of funds for developing nations was conducted which included a review of funds by:

- Origin

Donor countries have been grouped into three sectors:

- Organization of Economic Cooperation and Development (OECD)

- Organization of Petroleum Exporting Countries (OPEC)

- Centrally Planned Economies (CPE)

- Transfer channel

- Official bilateral

- Official multilateral

- Private banking

- Nature of the transfer

- Concessionary (Official Development Assistance)

- Non-concessionary

Figure 1.1 presents the framework for analysis which identifies the paths which funds follow from the donor countries through alternate channels to the developing country. The relative importance of each channel is identified in Table 1.1. Of the $\$ 64$ billion funneled to the developing world in 1977, the largest channel was bilateral non-concessional transfers (loans at the prevailing interest rate) by the large industrial countries who are members of the Development Assistance Committee (DAC) of the Organization of Economic Cooperation and Development (OECD). These transfers are primarily export credit financing provided by the Export-Import Bank of the United States, Germany's Hermes, France's Compagnie Francaise d'Assurance pour le Commerce Exterieur, and England's Export Credits Guarantee Department. This transfer channel is significant to photovoltaics since it can potentially provide loan terms up to 20 years for major development projects.

The second largest channel of funds for the developing world is commercial banks through their traditional lending activities. International commercial bank lending provided 2.5 times as much money in 1977 as all multilateral financial institutions combined, including the World Bank and the various regional development banks. A popular misconception overestimates the magnitude of funds provided by these multilateral institutions. 
Over the past decade there has been a general decline in the importance of Official Development Assistance (foreign aid or concessionary loans), but it still accounts for approximately $30 \%$ of total transfers. Figure 1.2 illustrates this decline as a percentage of total transfers. The decline in Official Development Assistance has been accompanied by an increase in non-concessionary loans. The increase in non-concessionary transfers has resulted in a significant rise in the accumulated debt of the Third World. By 1977 outstanding claims against the developing countries reached $\$ 244$ billion compared to $\$ 95$ billion only five years ago.

FIGURE 1.1

\section{FUNDS TRANSFERS TO A DEVELOPING COUNTRY}

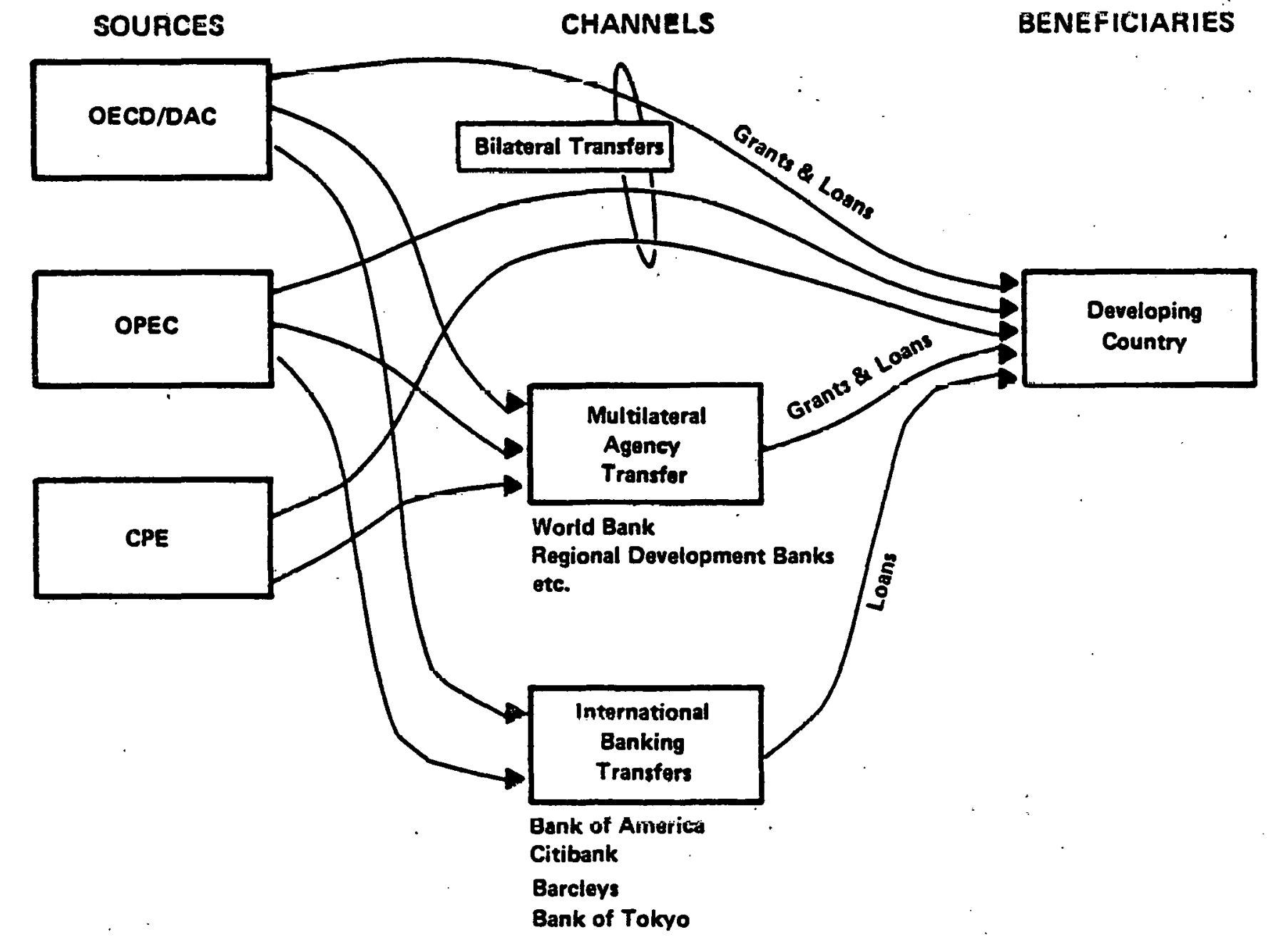

OECD Organization for Economic Co-operation and Development

OPEC Organization of Petroleum Exporting Countries

CPE Centrally Planned Economies

DAC Development Assistance Committee 
TABLE 1.1

PERCENTAGE TOTAL NET RESOURCES OF DEVELOPING COUNTRIES

FROM ALL SOURCES

(NET DISBURSEMENTS)

1977

\begin{tabular}{|c|c|c|c|c|}
\hline \multirow[b]{2}{*}{ Transfer Channel } & \multicolumn{3}{|c|}{ Nature of Funds Transfer } & \multirow[b]{2}{*}{ TOTALS } \\
\hline & ODA & $\begin{array}{c}\text { Non- } \\
\text { Concessional } \\
\text { Transfers }\end{array}$ & $\begin{array}{l}\text { Bank } \\
\text { Lending }\end{array}$ & \\
\hline $\begin{array}{l}\text { Bilateral } \\
\text { - OECD/DAC } \\
\text { - OPEC } \\
\text { - CPE }\end{array}$ & $\begin{array}{r}15.9 \% \\
5.8 \% \\
1.1 \%\end{array}$ & $\begin{array}{c}35.3 \% \\
1.3 \% \\
--\end{array}$ & $\begin{array}{l}-- \\
--\end{array}$ & $\begin{array}{r}51.2 \% \\
7.1 \% \\
1.1 \%\end{array}$ \\
\hline Multi-lateral & $7.8 \%$ & $4.8 \%$ & -- & $12.6 \%$ \\
\hline International Bank Lending & -- & -- & $27.8 \%$ & $27.8 \%$ \\
\hline TOTALS & $30.6 \%$ & $41.4 \%$ & $27.8 \%$ & $100.0 \%$ \\
\hline
\end{tabular}

Memorandum:

Private Sector Grants

Figures may not add due to round-off error.

DAC - Development Assistance Committee

OPEC - Organization of Petroleum Exporting Countries

CPE - Centrally Planned Economies

OECD - Organization for Economic Cooperation and Development

FIGURE 1.2

PERCENTAGE OF TOTAL NET RESOURCES RECEIPTS OF DEVELOPING COUNTRIES BY NATURE OF TRANSFER

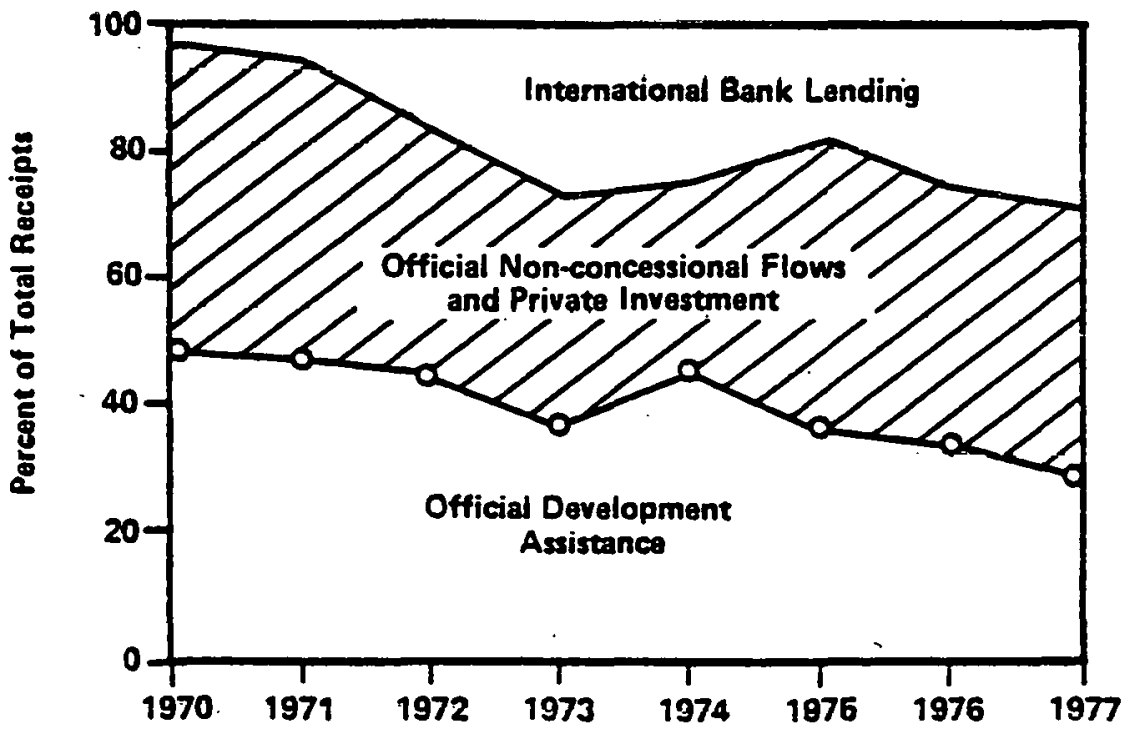


One measure of credit worthiness is the magnitude of outstanding debt that has previously been extended by both official public institutions and private commercial institutions. The geographic distribution of outstanding debt, as well as the public/private mix, is presented in Figure 1.3. Latin America carries the largest percentage of the total outstanding debt, having been highly favored by private commercial lending institutions. South Asia, with a lower absolute magnitude of debt, has been unable to obtain strong commercial bank support and continues to rely on official non-concessionary and concessionary loans. 


\section{FIGURE 1.3}

EXTERNAL PUBLIC DEBT OF 96 DEVELOPING COUNTRIES BY REGION (DISBURSED ONLY)

1976
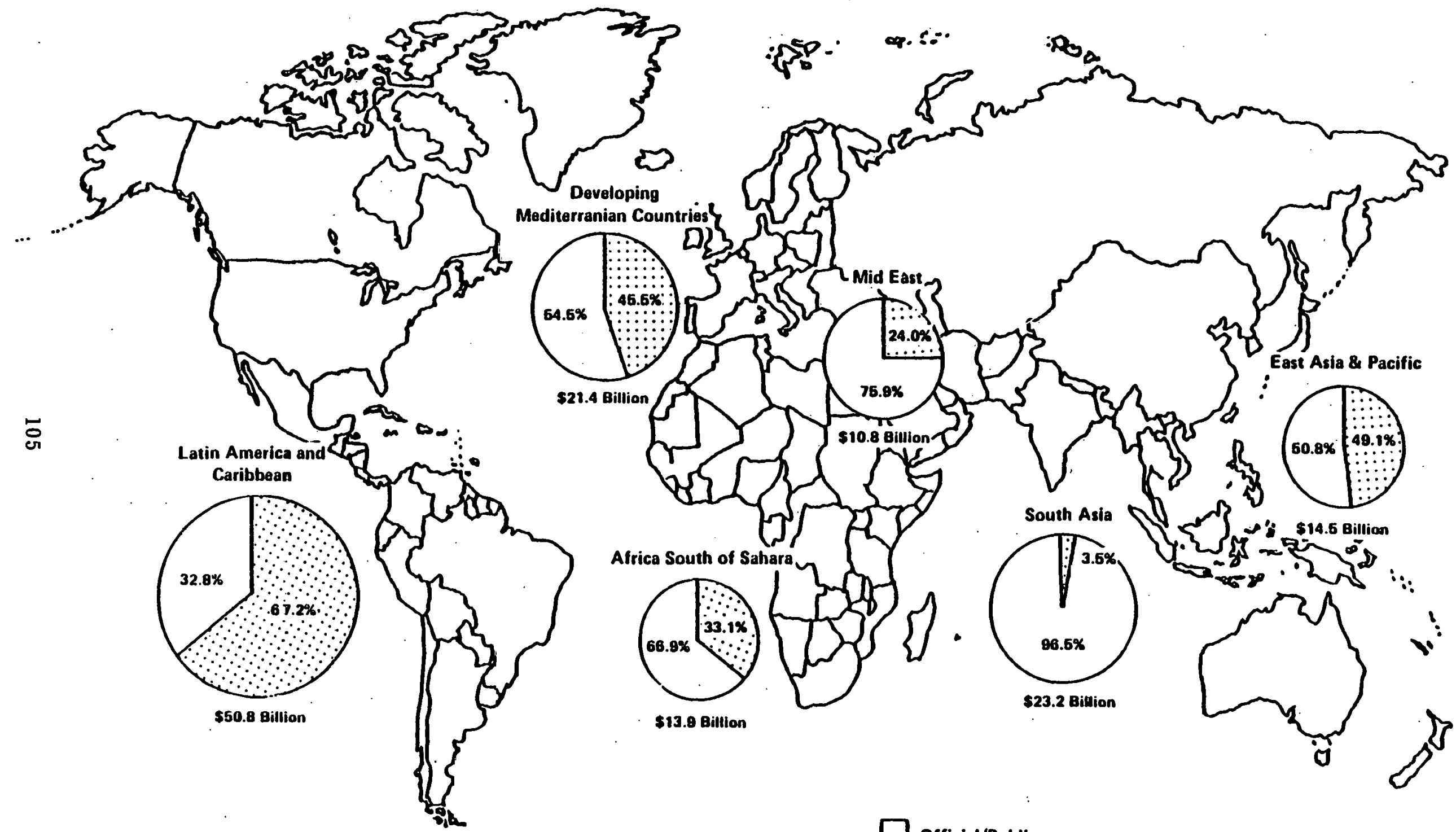

$\square$ official/Public

T Commercial/Private

World Bank Data 

institutions:

This study includes a review of the following multilateral

- World Bank (IBRD and IDA)

- Regional development banks

- Asian Development Bank (ADB)

- African Development Bank (AfDB)

- Inter-American Development Bank (IDB)

- Caribbean Development Bank (CDB)

- OPEC institutions

- United Nations Development Program (UNDP)

- International Monetary Fund (IMF)

The sources and uses of funds from each institution are identified and discussed. Major solar projects are identified and attitudes trwards photovoltaics are assessed.

These international multilateral institutions are ranked by the relative size of 1978 disbursements in Figure 1.4. Over $46 \%$ of the total multilateral funds approved in 1978 were from the World Bank. OPEC institution disbursements have increased sharply, such that in 1978 OPEC represented the second largest source of multilateral funds. Table 1.2 reports the principal Arab/OPEC development fund disbursements, and shows how the funds have increased almost 35 fold in the four year period from 1973 to 1977.

The distribution of loans by sector for the World Bank (IBRD and IDA) is presented in Figure 1.5. The two sectors which dirertly impact photovol tascs are the Agriculture and Rural Development Sector, which received $38.9 \%$ of the 1978 disbursements, and the Power Sector, which received $13.6 \%$ of the 1978 disbursements. For these two sectors, Figure 1.6 totals disbursements from all official multilateral institutions. It should be noted that Agriculture and Energy Sectors only represent one-third of the total funds distributed by these multilateral institutions.

The acknowledged policy of the development banks is to direct fund's toward the Least Developed Countries, and especially toward the agricultural poor. This policy has caused a definite trend to increase agricultural and rural development funds, while reducing energy disbursements. Energy sector programs have shifted their emphasis to oil exploration and hydroelectric dam construction, rather than toward al ternative sources of energy such as solar. The Agriculture Sector is more receptive to plans for distributed electricity generation for water pumping than the Energy Sector. 


\section{FIGURE 1.4}

FUNDS APPROVED BY INTERNATIONAL MULTILATERAL INSTITUTIONS 1978

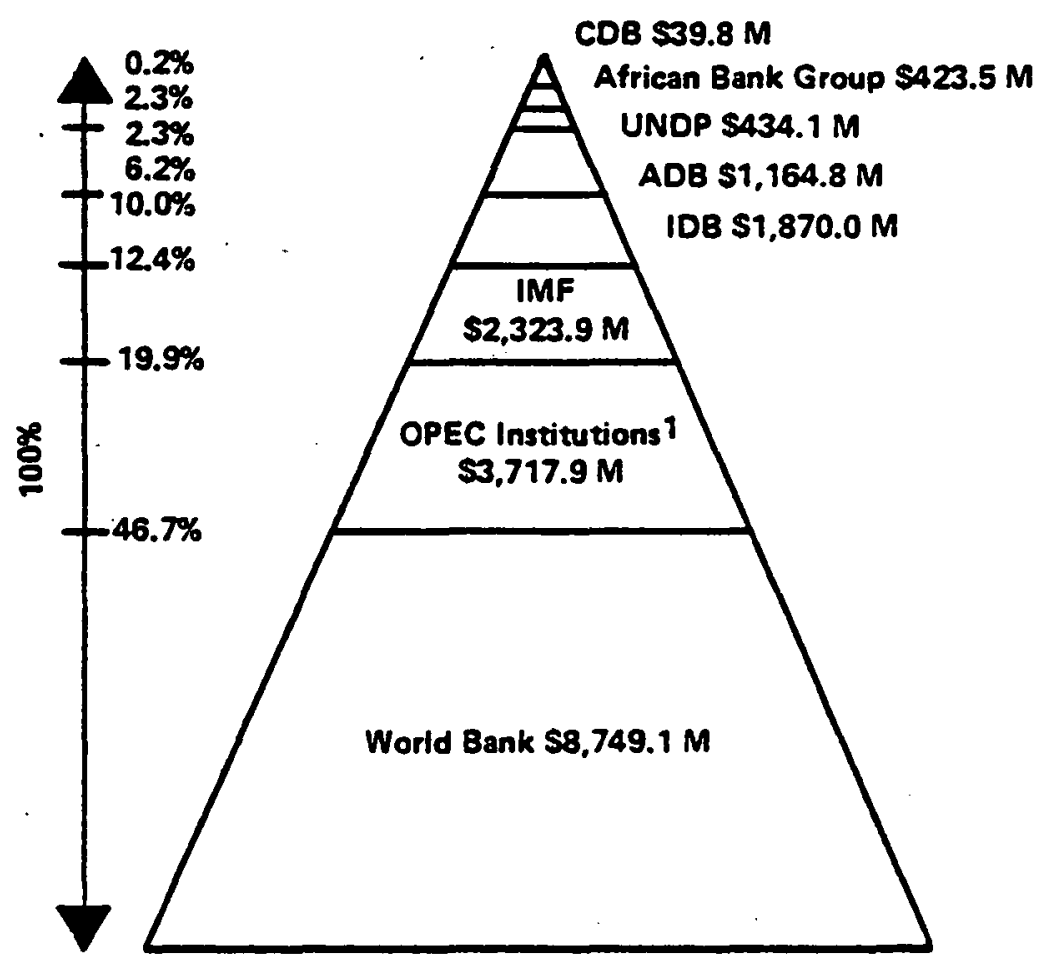

$\$ 18,723.1 \mathrm{M}$

1 Amount indicated for OPEC Institutions is for 1977. 
TABLE 1.2

MAJOR ARAB/OPEC AID INSTITUTIONS

\begin{tabular}{|l|c|c|c|c|c|c|c|}
\hline & \multicolumn{2}{|c|}{ Commitments } & \multicolumn{5}{c|}{$\$$ Millions } \\
\cline { 2 - 8 } & Formed & $\begin{array}{c}\text { \# Pro.jects } \\
\text { March 78 }\end{array}$ & 1973 & 1974 & 1975 & 1976 & 1977 \\
\hline \multirow{2}{*}{ Kuwait Fund } & 1953 & 44 & 59.5 & 143.4 & 343.1 & 324.5 & 411.8 \\
AFESD & 1972 & 24 & -- & 127.3 & 200.8 & 336.3 & 362.6 \\
Abu Ohabi Fund & 1971 & 13 & -- & 55.1 & 46.2 & 169.4 & 138.1 \\
Saudi Fund & 1967 & 24 & -- & -- & 282.7 & 458.3 & 841.1 \\
BADEA & 1973 & 24 & -- & -- & -- & 79.5 & 76.0 \\
OPEC Special Fund & & 10 & -- & -- & -- & 42.7 & 243.0 \\
ISDB & & 6 & -- & -- & 120.3 \\
\hline & & & 59.5 & 325.8 & 872.8 & $1,410.7$ & $2,192.9$ \\
\hline
\end{tabular}

AFEESO - Arab Fund for Economic and Social Development

BADEA - Arab Bank for Economic Development in Africa

IsDB - Islamic Development Bank

Source: $O E C D$ 


\section{FIGURE 1.5}

WORLD BANK (IBRD AND IDA) DISTRIBUTION OF LOANS BY SECTOR (Approvals)

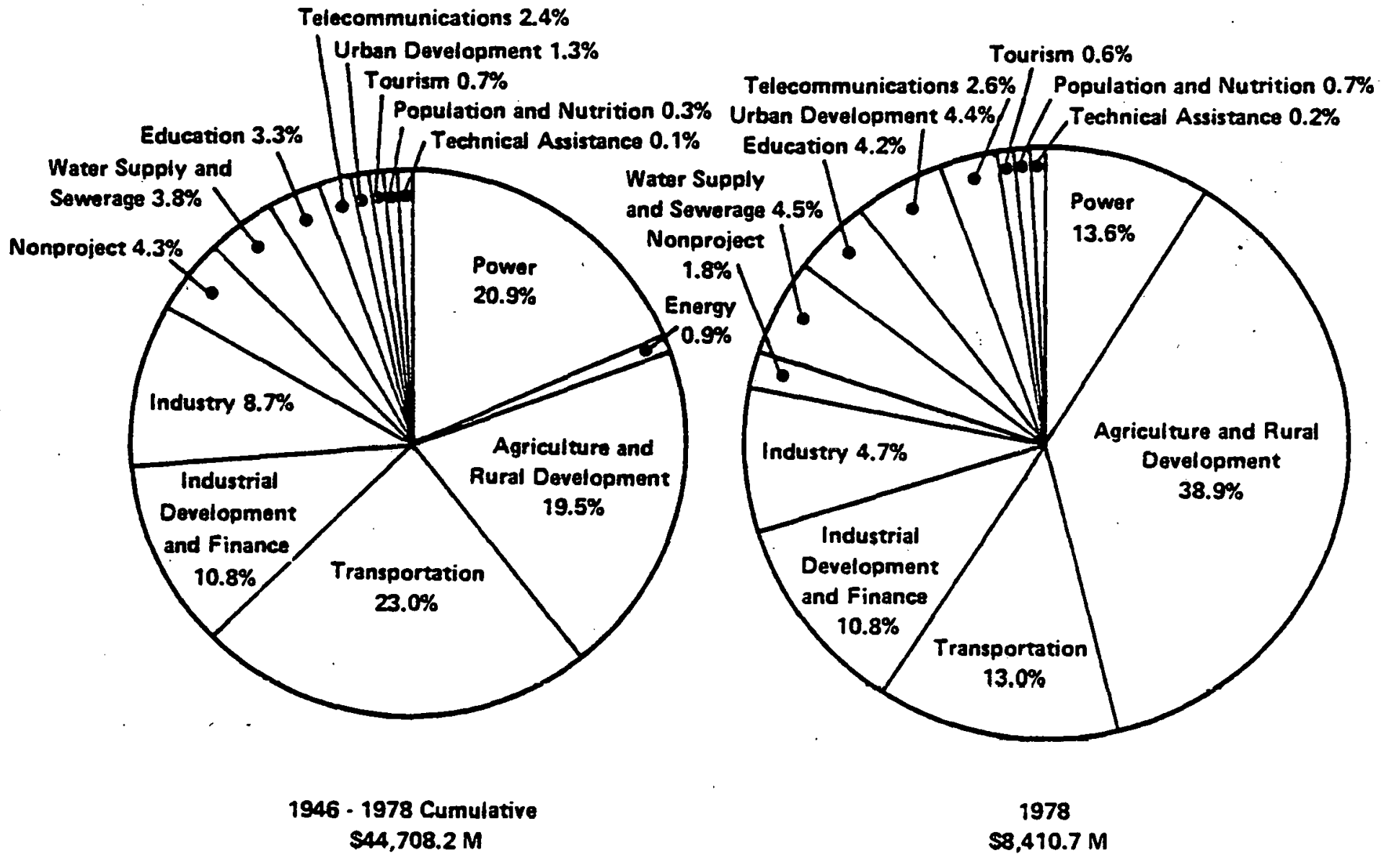

Source: World Bank 
FIGURE 1.6

DISTRIBUTION OF FUNDS FROM MULTILATERAL INSTITUTIONS

1978

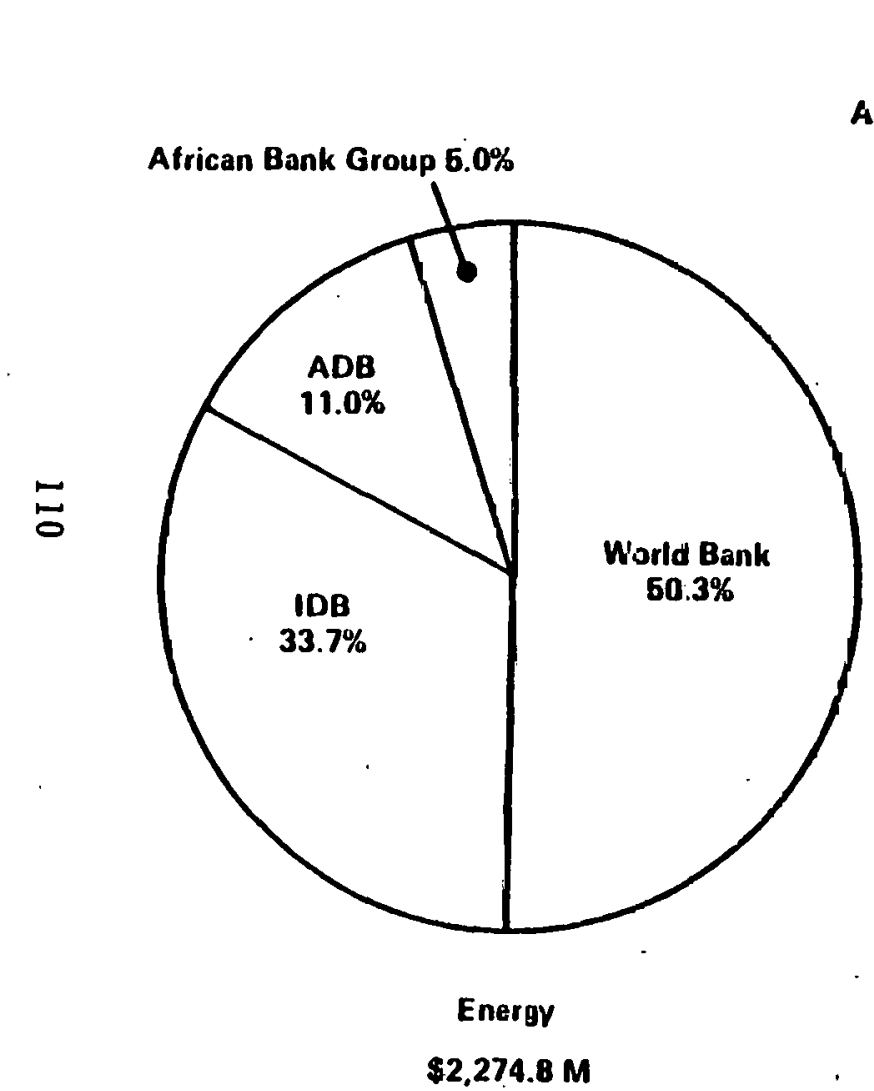

12.1\% of Approved Funding

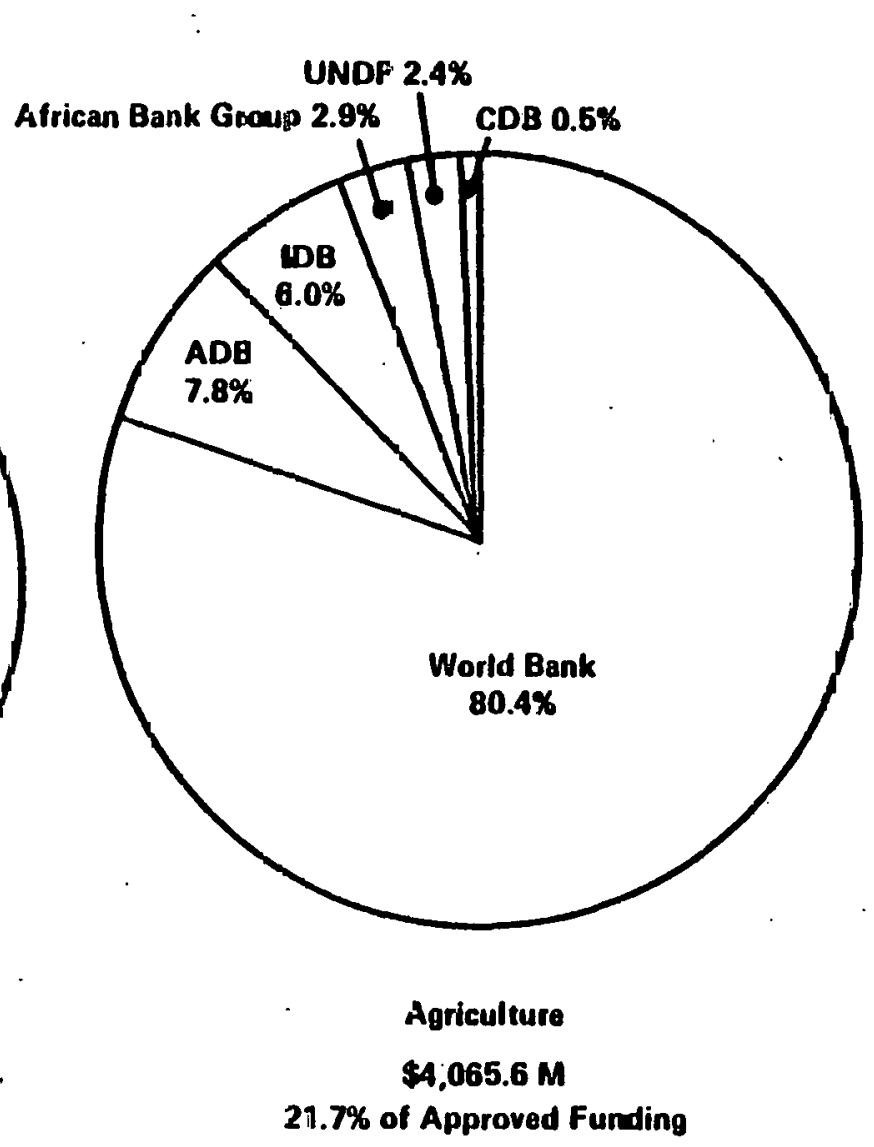

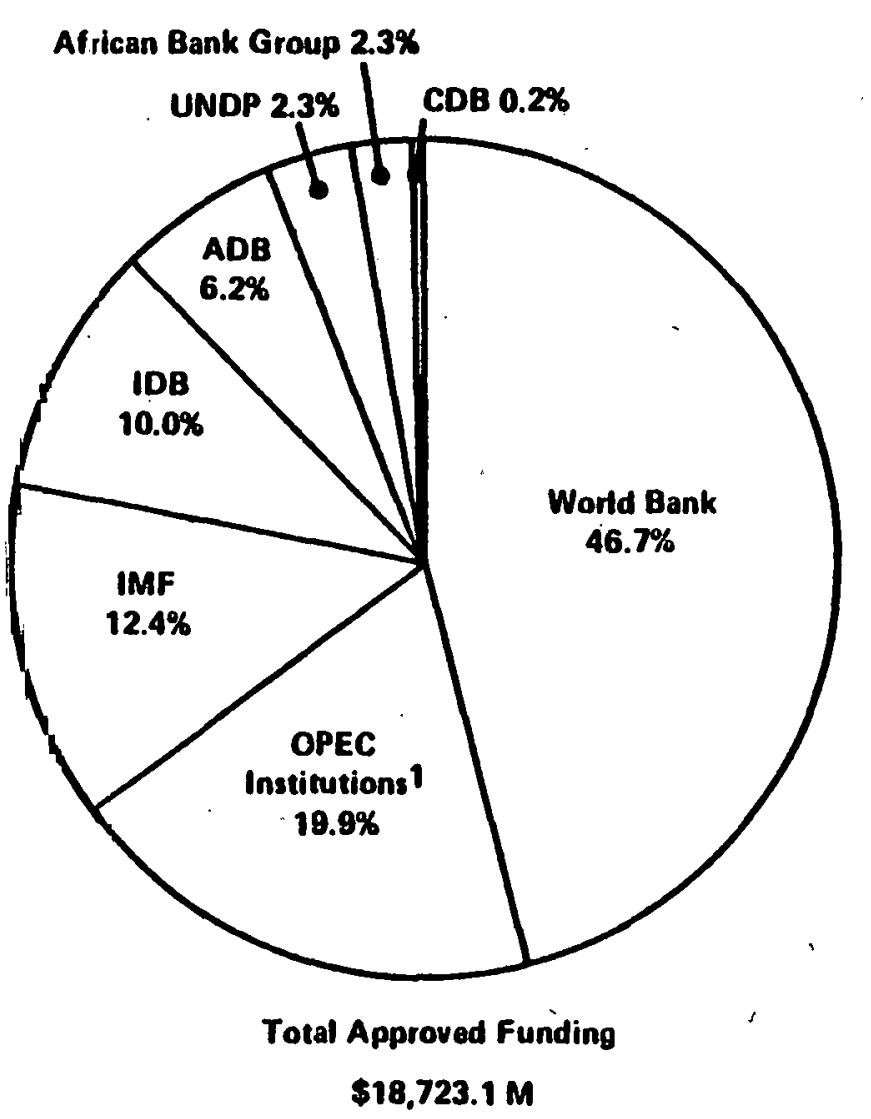

1 Amount indicated for OPEC Institutions is for 1977. 


\section{3 - INTERNATIONAL COMMERCIAL BANK LENDING}

The growing importance of commercial banks in financing the developing world required a review of the Eurocurrency Market and its strategic role in recycling balance of trade surpluses to the developing world. Changing banking practices in both the Western and Arab worlds are examined. The role of foreign government participation in foreign commercial banks and the use of these banks as instruments of these government's foreign policy are identified.

U.S. commercial banks have sharply increased their international loan activities to industrialized and developing nations in the past decade. Among the major U.S. banks are several with one-half to three-quarters of their total assets and earnings abroad. This has been accompanied by increased U.S. government regulation of foreign loans, and U.S. government discriminatory tax treatment for foreign loans of U.S. banks, placing U.S. suppliers at a competitive disadvantage in selected foreign markets.

Data on outstanding debt to developing countries by U.S. banks is maintained by the Federal Reserve. Table 1.3 lists the ten nations in greatest debt to U.S. commercial banks, which account for $70 \%$ of the total outstanding U.S. debt to developing countries. 
TABLE 1.3

FOREIGN EXPOSURE OF US BANKS

DECEMBER 1978

$\$$ Billions

\begin{tabular}{|c|c|c|c|c|}
\hline & Total & $\begin{array}{l}\text { Maturity } \\
\quad 1 \mathrm{Yr}\end{array}$ & $\begin{array}{l}\text { Distribution } \\
1-5 \text { Yrs }\end{array}$ & $\begin{array}{l}\text { of Claims } \\
5 \text { Yrs }\end{array}$ \\
\hline $\begin{array}{l}\text { 0il Exporting Developing } \\
\text { Countries }\end{array}$ & 20.0 & 11.4 & 6.7 & 1.9 \\
\hline $\begin{array}{l}\text { Non-0il Exporting } \\
\text { Developing Countries } \\
\text { - Latin America } \\
\text { \& Caribbean } \\
\text { - Asia } \\
\text { - Africa }\end{array}$ & $\begin{array}{r}35.5 \\
13.7 \\
2.9\end{array}$ & $\begin{array}{r}16.0 \\
9.5 \\
1.4\end{array}$ & $\begin{array}{r}15.2 \\
3.2 \\
1.3\end{array}$ & $\begin{array}{l}4.2 \\
1.0 \\
0.2\end{array}$ \\
\hline Total Developing World & 72.1 & 38.3 & 26,4 & 7.3 \\
\hline $\begin{array}{l}\text { GRAND TOTAL (Ueveloped } \\
\text { and Developing World) }\end{array}$ & 217.3 & 147.8 & 53.6 & 15.9 \\
\hline
\end{tabular}

\begin{tabular}{|c|c|c|c|c|}
\hline $\begin{array}{c}\text { Ten Most Indebted } \\
\text { Developing Countries }\end{array}$ & Total & $\begin{array}{l}\text { Maturity } \\
1 \text { Yr }\end{array}$ & $\begin{array}{l}\text { Distribution } \\
\mid 1-5 \text { Yrs }\end{array}$ & $\begin{array}{l}\text { of Claims } \\
5 \text { Yrs }\end{array}$ \\
\hline $\begin{array}{l}\text { Brazil } \\
\text { Mexico } \\
\text { Venezuela } \\
\text { Korea } \\
\text { Chirid (Talwan) } \\
\text { Philippines } \\
\text { Argentina } \\
\text { Iran } \\
\text { Indonesia. } \\
\text { Algeria }\end{array}$ & $\begin{array}{r}13.4 \\
10.7 \\
7.5 \\
3.8 \\
3.3 \\
2.8 \\
2.8 \\
2.6 \\
2.2 \\
1.8\end{array}$ & $\begin{array}{l}4.7 \\
4.5 \\
5.1 \\
2.7 \\
2.3 \\
1.8 \\
1.5 \\
1.2 \\
1.0 \\
0.4\end{array}$ & $\begin{array}{l}6.7 \\
4.6 \\
2.0 \\
0.8 \\
0.9 \\
0.7 \\
1.1 \\
1.1 \\
0.9 \\
1.1\end{array}$ & $\begin{array}{l}2.0 \\
1.5 \\
0.5 \\
0.2 \\
0.1 \\
0.4 \\
0.2 \\
0.3 \\
0.3 \\
0.3\end{array}$ \\
\hline TOTAL $\quad(10)$ & 50.9 & & & \\
\hline
\end{tabular}

Source: Federal Reserve

1.4 COUNTRY RISK ANALYSIS

Since the borrower's credit rating is the key variable for commercial bank lending, considerable efforts by the banking community have been devoted to "country risk analysis". Country risk analysis is the process by which lending institutions establish the fundamental credit worthiness of a nation. Country risk is assessed through a combination of quantitative and qualitative analyses. Through personal interviews with a broad profile of commercial institutions, a qualitative country risk assessment was developed for solar commercial opportunities. Table 1.4 provides a summary of this assessment. 
TABLE 1.4

DEVELOPING COUNTRIES

SOLAR COMMERCIAL OPPORTUNITIES - COUNTRY RISK

\begin{tabular}{|c|c|c|c|c|c|}
\hline & A & B & C & D & $\mathbf{E}$ \\
\hline Geographical & Best & Good & $\begin{array}{l}\text { Sat isfactory } \\
\text { (With Care) }\end{array}$ & $\begin{array}{c}\text { Govt. Assistance } \\
\text { Candidates }\end{array}$ & Poor \\
\hline South Asia & -- & -- & - & $\begin{array}{l}\text { India } \\
\text { Pakistan }\end{array}$ & Bangladesh \\
\hline $\begin{array}{l}\text { Africa } \\
\text { South of Sahara }\end{array}$ & - & South Africa & $\begin{array}{l}\text { Ivory Coast } \\
\text { Liberia } \\
\text { Cameroon } \\
\text { Kenya } \\
\text { Senegal }\end{array}$ & $\begin{array}{l}\text { Nigeria } \\
\text { Botswana } \\
\text { Zimbabwa- } \\
\text { Rhodesia }\end{array}$ & $\begin{array}{l}\text { Zaire Congo } \\
\text { Zambia Angola } \\
\text { Ghana } \\
\text { Ethiopia } \\
\text { Tanzania }\end{array}$ \\
\hline Far East & - & $\begin{array}{l}\text { Korea } \\
\text { Taiwan } \\
\text { Philippines } \\
\text { Thailand }\end{array}$ & $\begin{array}{l}\text { Papua, N.G. } \\
\text { Indonesia } \\
\text { Malaysia }\end{array}$ & Fiji & - \\
\hline $\begin{array}{l}\text { North Africa } \\
\& \text { Mid East }\end{array}$ & $\begin{array}{l}\text { Saudi Arabia } \\
\text { Kuwait } \\
\text { Algeria }\end{array}$ & $\begin{array}{l}\text { Egypt } \\
\text { Morocco }\end{array}$ & $\begin{array}{l}\text { Gabon } \\
\text { UAE } \\
\text { Oman } \\
\text { Quatar } \\
\text { Tunisia }\end{array}$ & $\begin{array}{l}\text { Iran } \\
\text { Jordan } \\
\text { Sudan }\end{array}$ & $\begin{array}{l}\text { Libya } \\
\text { Iraa } \\
\text { Syria }\end{array}$ \\
\hline $\begin{array}{l}\text { Central \& } \\
\text { South America }\end{array}$ & $\begin{array}{l}\text { Brazil } \\
\text { Mexico } \\
\text { Venezuela } \\
\text { Bahamas }\end{array}$ & $\begin{array}{l}\text { Argentina } \\
\text { Chile } \\
\text { Ecuador } \\
\text { Columbia } \\
\text { Trinidad \& } \\
\text { Tobago }\end{array}$ & $\begin{array}{l}\text { Panama } \\
\text { Costa Rica }\end{array}$ & $\begin{array}{l}\text { Peru } \\
\text { Uruguay } \\
\text { Guatamala } \\
\text { Paraguay }\end{array}$ & $\begin{array}{l}\text { Bolivia } \\
\text { Jamaica } \\
\text { Haiti }\end{array}$ \\
\hline $\begin{array}{l}\text { Mediterranean } \\
\text { Developing } \\
\text { Countries }\end{array}$ & Spain & $\begin{array}{l}\text { Greece } \\
\text { Israel }\end{array}$ & $\begin{array}{l}\text { Yugos lavia } \\
\text { Portugal }\end{array}$ & Turkey & Cyprus \\
\hline
\end{tabular}


The Export-Import Bank of the United States (Eximbank) has been extremely active in supporting U.S. export sales and co-financing with the U.S. commercial banks. As shown by a comparison of Table 1.5 and Table 1.3, U.S. Export-Import Bank Exposure, four of the top five countries appear on both the list for the largest outstanding claims against U.S. banks and the list for the largest outstanding claims against the Export-Import Bank. These four countries are:

\author{
- Brazil \\ - Mexico \\ - Korea \\ - China (Taiwan)
}

TABLE 1.5

US EXPORT/IMPORT BANK EXPOSURE SEPTEMBER 30, 1978

\begin{tabular}{|l|c|}
\hline \multicolumn{1}{|c|}{ Country } & \$ Million \\
\hline Mexico & 1,847 \\
Korea & 1,832 \\
Spain (Taiwan) & 1,727 \\
China (Taiwi & 1,764 \\
Brazil & 1,616 \\
Algeria & 1,325 \\
Japan & 907 \\
Yugos lavia & 859 \\
\hline
\end{tabular}

Source: U.S. Eximbank

Co-financing is the practice in which a commercial bank and Eximbank may juintly fund a lärge development project. A common co-financing arrangement permlts the commercial bank to receive its full payment during the early years while the Eximbank is repayed during the later years of the loan agreement. The period covered by the commercial bank is a matter of negotiations and a function of the particular project. Normally, commercial banks limit loans to seven years, however, recent loans on nuclear power plants have reached 12 to 15 years. Eximbank will then accept terms beginning at the end of the commercial bank loan and continuing on to a total of 20 years. Photovoltaic projects in the form of large rural electrification projects or regional agricultural irrigation programs should qualify for similar long-term co-financing. 


\subsection{IMPLICATIONS FOR THE PHOTOVOLTAIC INDUSTRY}

Six underlying principals have been identified during this study which should guide the policies of both the photovoltaic industry and the U.S. government as each establishes policy for the export market.

(1) Economic Viability Must Be Established

The single most important variable controlling future market growth for photovoltaics is its economic viability compared to alternative forms of remote site power. Once economic viability is established and proven, more funds will be made available than the industry can absorb. The financial community must be convinced that photovoltaics is the best long-term alternative.

Both commercial and private financial institutions want solar energy to succeed. They will support it, in fact bend to support it, when it approaches cost effectiveness. Broad industrial development will be easily achieved once the economics and reliability are established.

(2) U.S. Government Is Responsible For Establishing Technical and Economic Viability

The attitude of the development banks and foreign recipients is clearly that it is the responsibility of the U.S. government to underwrite the expense necessary to establish technical and economic viability of photovoltaics in their markets. Once technical and economic viability have been established, normal commercial and development financing channels will carry the world photovoltaic market to exponential heights.

(3) The Export-Import Bank is Key to Long-term Financing

Since solar energy systems are capital intensive, long-term financing Is necessary in order that "life cycle cost" can indeed approach "annual variable cost". Because it is the practice of commercial banks to limit their loans to five to seven years under normal conditions, the U.S. Export-Import Bank, through the mechanism of co-financing, is the most likely source to achieving long-term financing. A standard practice for the Eximbank in major capital improvement programs in the Third World has been to cooperate on a pari passu basis with commercial banks. In this manner for a given project short-term maturities are carried by the commercial banks, while long-term maturities are carried by Eximbank. This technique is directly applicable to photovoltaics if the buyer is credit worthy and the project is large enough to interest Eximbank. A key recommendation deals with this issue. 
(4) Commercial Bank Support Is Available In Good Credit Risk Countries But First Photovoltaics Must Be "Sold"

Though commercial banks have historically provided funds to developing countries considered good credit risks, they must be convinced that photovoltaic systems are sound investments. Commercial banks have demonstrated a more rapid response capability than multilateral development banks. However, before this more available source of funds can be used, these financiers require current information on the state of photovoltaic developments, their economics, and their satisfactory performance.

(5) World Bank and Regional Development Banks Are Emphasizing Agricultural Development

Since the World Bank and the regional development banks have placed priority upon the development of the agricultural porr, projects that incorporate photovol taics into agricultural development, for example, irrigation or water pumping applications, are good prospects for World Bank support once economic viability is established. These projects, however, should be submitted through the Agricultural Sector. Proposals should not be routed through the Energy Sector where preference is being given to hydroelectric development, petroleum exploration, and nuclear energy development.

The project cycle for the World Bank is detailed in the report. The cycle requires typically three years and involves extensive work with the receiving country. In spite of the long time frame required, this may be a practical avenue to follow in very large reglonal development progi ailis.

The influence of the World Bank exceeds its available funds. Some commercial banks are interested in co-financing with the World Bank since they feel that the World Bank and other development banks have greater "political influence" with the governments of developling countries in the everit a loan gets into difficulty. Development banks, along with the IMF, ran cause policy changes in the recipient country's government that commercial banks cannot demand. 
(6) Añ Exporter's Strategy Must Be Country Specific

A different approach to export must be taken in those countries considered good credit risks than in those countries considered to be poor credit risks. Good credit risk countries are candidates for commercial bank lending and Eximbank financing. In poor risk countries, longer term development projects require World Bank or Official Development Assistance funds. If the U.S. Agency for International Development (AID) Program coincides with markets or opportunities for photovoltaics, then poor credit risk countries may offer near term opportunities. 


\subsection{RECOMMENDATIONS FOR GOVERNMENT POLICY}

These recommendations are intended to further the primary objective of the international photovoltaic program, which is to accelerate the widespread use of photovol taics in international markets. These recommendations are predicated on the thesis that through stimulating exports for United States manufacturers, the photovol taic industry production volume can be increased. With a substantial increase in volume, prices for photovol taics will decline to a price level appropriate for domestic market applications.

In order to stimulate exports, there are clearly two separate international markets that must be addressed as elements of the U.S. International Photovoltaic Plan. These are:

- The Commercial Market

- The Foreign Assistance Market

The commercial market includes those countries which are deemed credit worthy by commercial lending institutions. The foreign assistance market includes those countries which are deemed not credit worthy by commercial lending institutions, and by virtue of their economic plight, are beneficiaries of official development assistance from the developed world and concessionary funds from development banks.

The primary thrust of the U.S. program should be toward the commercial market, though not at the total exclusion of programs in the foreign assistance market. The reasons for this emphasis are that the commercial market:

- Has the financial resources in hand to undertake major rural electrification or agricultural development programs.

- Has already used conventional sources to meet urban electrification requirements, understands the costs of electrification programs, and now seeks rural electrification.

- Responds more rapidly to market development efforts, hence could provide larger volume demand for industry at an earlier date.

- is generally more stable politically. 
In order to stimulate both of these market sectors, recommendations for the international photovoltaic plan have been divided into three sets:

- Commercial Market Development Activities

- A set of special recommendations focused on the commercial market opportunity

- Foreign Assistance Market Development Activities

- A set of special recommendations focused on the foreign assistance market opportunity

- General Support Activities

- A set of general recommendations which are necessary to support both of the market-focused programs

Each of these three activity areas is described below.

\subsubsection{COMMER CIAL MARKET DEVELOPMENT ACTIVITIES}

Key elements of the commercial market program include:

- Eximbank Program

- Demonstration Program

- Commercial Bank Education Program

- Photovoltaic Technical Assistance Program

As a result of this investigation, the following are specific recommended programs which would enhance the export opportunities for photovol taic systems for U.S. manaufacturers to commercial markets:

\section{EXIMBANK PROGRAM}

The Export-Import Bank of the United States should undertake a program to:

- Establish special solar project criteria under which 10-12 year funds would be available for Buyer Credit to finance photovoltaic installations abroad. This program should include provisions for co-financing with commercial banks on a pari passu basis that would permit the commercial banks to take the early maturities while Eximbank could take the later maturities. 
- Define a minimum threshold for solar projects below the level currently set for Buyer Credit Programs.

- For the first year the recommended threshold for solar project funding should be $\$ 250,000$ (the equivalent of installing 10-15 photovol taic water pumps, or electrifying two small villages)

- In succeeding years, the minimum solar project threshold could be increased annually until it complies with the standard \$1 million criteria of Eximbank for Buyer Credits.

\section{COMMER CIAL DEMONSTRATION PROGRAM}

Fund a serles of U.S. demonstration projects in key credit worthy countries, such as:
- Venezuela
- Brazil
- Mexico
- Argentina
- Indonesia
- Philippines
- Columbia

Commercial demonstration projects must be conducted in cooperation with local power or rural electrification authorities, and have the support of the developing country's government. If satisfactory, the host country could buy the demonstration project after an agreed upon time period. Typical demonstration projects could include irrigation projecte for regional agricultural cuoperatlves, i.e. the Coffee Trust, or other comparable agencies with broad requirements. It may be possible to cooperate with the . commercial banks in the selection of an appropriate recipient country and agency.

Data on costs for these installations will have to be rnllected and analyzed relative to costs of competing forms of energy in each country.

\section{TAX CONCESSIONS TO BANKS FOR FOREIGN SOLAR LOANS}

Review and revise current tax regulations as applied to foreign loans by commercial banks for solar energy systems. A key revision would be to allow for preferential or full domestic tax credit for foreign taxes and fees paid on solar energy system export-financing loans. 


\section{COMMER CIAL BANK EDUCATION PROGRAM}

Initiate a special photovol taic information program for the U.S. financial community to provide data on:

- Existing photovol taic installations

- Economic feasibility of systems

- Emphasis on business/commercial aspects of distributed electricity generation

- Cost analysis of photovol taics relative to diesel fuel systems or grid extensions

- Projected cost reductions

- Types of systems currently available from U.S. manufacturers

- Reliability of systems

\section{PHOTOVOLTAIC TECHNICAL ASSISTANCE PROGRAM}

A formal photovoltaic technical assistance program should be developed to assist foreign countries in preparing technical specifications related to particular applications and to assist in the preparation of loan applications for financial institutions. This program would provide the technical photovol taic expertise to foreign users who are not familiar with the design of photovol taic systems. These preliminary designs are necesary for bid solicitations, and would also serve to train the foreign buyer in designing photovol taic systems.

Commercial markets will require engineering companies, major construction companies, or the equivalent of the architect and engineering firms to become familiar with photovol taic systems. These companies will then perform this function for a fee.

\subsubsection{FOREIGN ASSISTANCE MARKET DEVELOPMENT ACTIVITIES}

Key elements of the development program to address the foreign assistance market are the following:

- Foreign Assistance Demonstration Program

- Development Bank Education Program

- AID Technical Assistance Program 


\section{FOREIGN ASSISTANCE DEMONSTRATION PROGRAM}

In contrast to the commercial demonstration program, the selection criteria for the foreign assistance market will emphasize the:

- Low income, lower middle income and intermediate middle income countries

- World geographic distribution

Demonstration sites should be selected in consultation with AID. However, general recommendations from this analysis are as follows:

\section{RECOMMENDED SITES FOR AID DEMONSTRATION}

\section{REGION}

Asia

Africa, South of the Sahara

Far East

North Africa

\& Mid East

Central \&

South America

Mediterranean

Developing

Countries

\section{PRIMARY}

Pakistan

Kenya

Nigeria

Senegal

Fiji

Egypt

Sudan

Peru

Chlle

Turkey

\section{SECONDARY}

Bangladesh

Malawi

Botswania

Malaysia

Jordan

Costa Rica

\section{DEVELOPMENT BANK EDUCATION PROGRAM}

The education program for development hanks differs from the education program for commercial banks primarily in respect to the social humanitarian benefits which could be derived by the recipient. Identification of the least cost economic alternative is important, however, social benefits to the extreme poor from agricultural development, improved medical services, or reduced birth rates are also considered by the development banks. 
The market impact will come from educating the staff of the various development banks on the economic and social benefits of photovoltaics in order that bank personnel can recommend photovoltaics to their beneficiaries.

The AID demonstration projects should be coordinated with the regional development banks in order to gain the greatest market impact.

\section{AID TECHNICAL ASSISTANCE PROGRAM}

Projects in the Least Developed Countries (LDCs) will require the trained technical support. AID will have to assist the LDC governments in the design and specification of new photovoltaic systems. While commercial opportunities will obtain this assistance from the traditional architectural and engineering (A\&E) construction firms, AID will have to provide this service either by paying the commercial A\&E firms or by using a U.S. national laboratory to perform the same function.

\subsubsection{GENERAL SUPPORT ACTIVITIES}

In support of both commercial and foreign assistance market development programs, the following general support programs are recommended:

- Technology Development Program

- International Economic Analysis Program

\section{TECHNOLOGY DEVELOPMENT PROGRAM}

The U.S. DOE Technology Development Program must continue on an aggressive development front. Costs must be constantly reduced to open ever-broadening markets. The U.S. must maintain its technological leadership over the balance of the industrialized world. Clever financial arrangements cannot overcome an inferior or expensive product. The U.S. must have a superior product that has high availability around the world.

There is, however, need for more attention to be devoted to the systems that operate in remote sites with photovol taic power. The key systems required are:

- Water pumping systems

- Small refrigeration systems

- DC lighting systems 


\section{INTER NATIONAL ECONOMIC ANALYSIS PROGRAM}

To support both commercial and development bank lending institutions, a series of economic analyses of the potential role of photovol taics in different market sectors is desirable to show the circumstances under which photovoltaics is the least-cost power alternative. Assessment should include examination of the role of photovoltaics in:

- Agricultural development, and

- Rural electrification.

Cost comparisons of distributed power generation versus centralized power generation must be developed for the financial community. The resulting benefits to the recipients, both economic and social, must be identified.

The agricultural impact assessment should include the impact of photovoltaics on levels of agricultural development, crop yields, livestock yields, water avallabllity, and water quality. Rural electrificatiun appraisals should seek the least-cost economic alternative comparing distributed with centralized electricity generation. The various economic alternatives examined should include evaluating the extension of an existing power grid or the use of small diesel engines. It is important that these economic analyses be accepted as realistic by the foreign buyers. 


\section{APPENDIX H}

PHOTOVOLTAIC ISSUES IN DEVELOPING COUNTRIES 


\section{APPENDIX H \\ PHOTOVOLTAICS ISSUES IN DEVELOPNG COUNTRIES}

This Appendix contains papers relating to photovoltaics systems and international marketing issues, particularly concerning developing or "Third World" countries.

Included are:

- A summary of the July 1979 Photovoltaic International Plan Meeting, prepared as a Massachusetts Institute of Technology Energy Laboratory working paper;

- "Photovoltaics in the Third World," prepared by Douglas Smith;

- "Photovoltaics in the Third World: Priorities of Consuming Countries Concerning Commercialization," prepared by Thomas P. Klcin; and

- "Transnational Issues of the International Photovoltaic Plan," prepared by Lewis J. Perclman and Sylvia H. Forman. 
H. 1 SUMMARY: PHOTOVOLTAIC INTERNATIONAL PLAN MEETING

MASSACHUSETTS INSTITUTE OF TECHNOLOGY, JUIY 9,1979

MIT Energy Laboratory Working Paper No.

MIT-EL-79-038WP

July 1979 
Summary of Photovoltaic International Plan Meeting, July 9, 1979 at Massachusetts Institute of Technology

The MIT workshop on the International Plan for Photovoltaics was convened at the request of SERI and the Jet Propulsion Laboratories to bring together a group of individuals in the Cambridge area who had specific expertise in energy planning and finance in the developing nations. Appendix one contains a listing of those individuals present at the workshop. The agenda and preliminary list of questions prepared for the workshop is included as appendix two. While the materials discussed covered in large part the listing included in appendix two, they were not discussed in order. The report which follows will not attempt to present a chronology of the discussion, but will rather present a summary of the major points which came out of the workshop and present a set of alternative approaches for develnpment of a photovoltaic market effort in the develnping nations.

Figure 1 presents a schematic diagram of the alternative pathways open to the photovoltaics industry in sales to end users in the developing nations. Only one of these alternatives represents direct sales while all of the other alternatives represent sales either to or through governmental agencies in this country or in the host country. The discussion surrounding this schematic focused on the fact that it was extremely unlikely that there would be direct sales of photovoltaic products to end users in the developing nations for two reasons. The first and most significant reason was that even though there was a market for water or possibly for pumping there was not a market. for energy divorced from its end use. As a result it was felt that there would not be a market for photovoltaics even though there might well be a market for a system such as an irrigation or village electrification which could be photovoltaic powered. The second reason for there not to be sales directly to end users was that the end users in the developing nations required extensive tinancing to be able to purchase any type of capital good. This financing most frequently comes through governmental intervention and then frequentiy through multilateral or bilateral financing agreements between the host nations and the doner nations.

The participants emphasized that there is a separation between "need" and "demand" which must be made whenever one discusses the market potential in the developing nations. Smith and others have analyzed the potential need for photovoltaic microirrigation systems yet there has not been demonstrated to be a demand. The need is present and it would appear that a demand might. also exist at a favorable system price. The demand has not been demonstrated and, indeed it will not be demonstrated until there is a sufficient number of systems fielded and financing available for the purchase of such systems. While farmers may see the need and understand it, their ability to translate that need into a demand required considerable additional assistance.

The above considerations led to a set of proposed methods of intervention which the DOE could follow to have an impact upon the potential market for photovóltaics in the developing nations. These are:

- Intervention into existing projects

- Informed manpower availability 
FIGURE 1

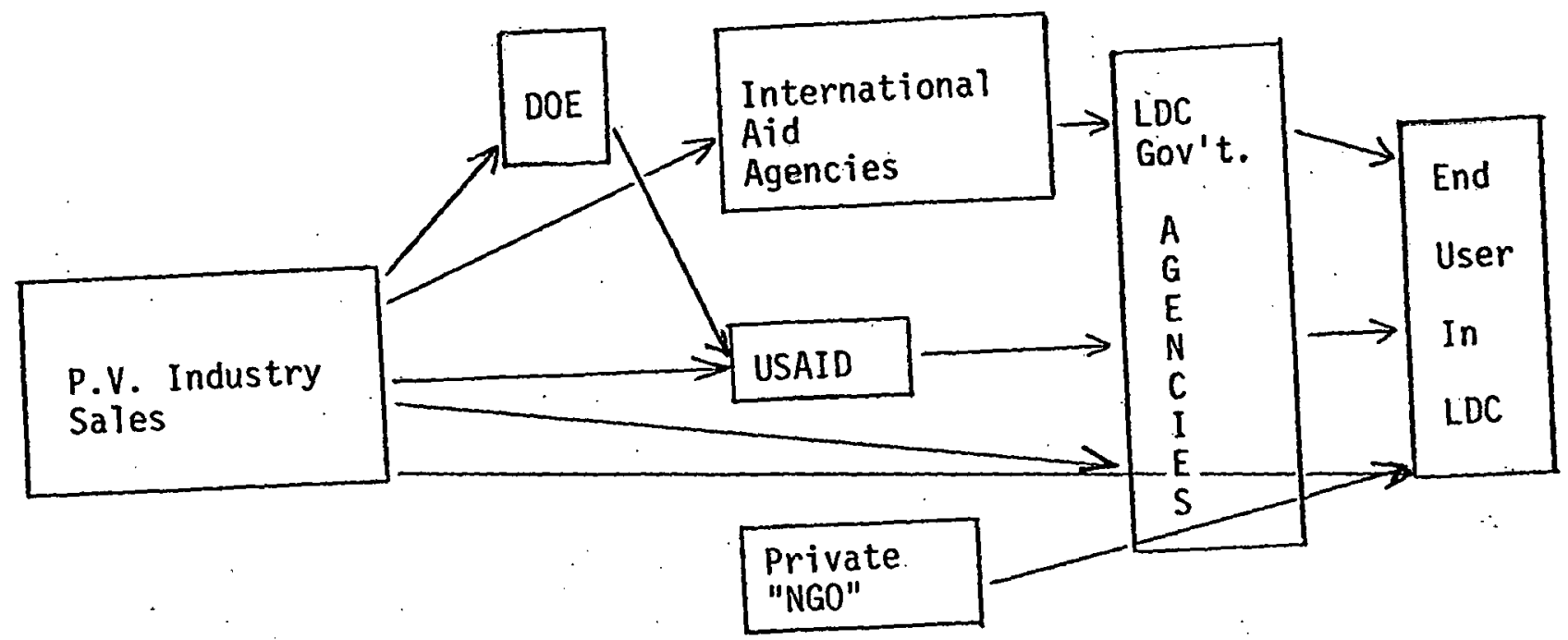


- Circular letters of project possibility inside of USAID

- Cooperative effort with oil nation development program

- Energy Technical training program

- Grass roots agency development and implementation program

At the conclusion of the discussions an executive session developed another alternative:

- Staged industry systems development and deployment

Intervention into existing projects.

The argument was made that it is not possible to design a project using a technology which is totally unproven but that it is possible to enter into a project which has been initiated and provide -- with guarantees of performance - a portion of the system requirments. The example given was in terms of the small scale irrigation projects which are underway in a number of countries. Were there to be an active intervention program developed it would be possible to add photovoltaic power systems into projects on irrigation both to test their viability and to begin to make the engineering and systems people who are responsible for the design of such projects aware of the potential of photovoltaics while convering all down side risk. In so doing, photovoltaic systems are seen and handled and are tested in an environment where they are compared directly with the competition. The sense of the meeting was that the type of intervention would offer the greatest possibility for a rapid entry into the sphere of international aid giving agencies as it would bring photovoltaic power systems into their ligitimate dicision and operating structure. To accomplish this effort would require that all differential costs be born outside of the irrigation (or other) project and that there be a guarantee of performance which if not met would require the replacement of the photovoltaic system by the dominant alternative.

Informed manpower availability.

A major consideration in choosing or not choosing a given alternative in development projects is information available to the development teams or missions which prepare the scope of a project. Given this requirement for information it was proposed that there be made available a cadre of trained and knowledgeable individuals who could -- at no cost to the aid agency -- be provided to missions concerned with either irrigation or with village electrification and who could introduce -- where applicable -photovoltaic power systems as alternatives in given projects. This proposal was considered as siginificant for two reasons. The first was that it would be possible to enter photovoltaics into the vocabulary of the projects themselves and the second was that it would be possible to act as educators of the more traditional loan officers and engineers/economists who people the aid missions today.

Circular letters of project possibilities inside of USAID.

Within USAID there is a channel by which circular letters may be distributed 
to all of the missions soliciting interest in a particular type of development activity. In the case of the photovoltaic technology such a letter would need to present the technology in brief, present a listing of likely applications of the technology with a brief description of each and then offer additional sources of information including a Washington drop point at which information and manpower could be directed toward a particular missions needs. Such a missile circulated within the USAID would have the advantage of reaching all of the missions and reaching a fairly broad spectrum of mission personnel. If acted upon it would offer programatic support in the field and would offer a mechanism by which a major program could be initiated. The approach has the disadvantage of requiring that there be an initial response from what may be an overtaxed staff within the mission.

Cooperative effort with an 0 il Nation Development Program.

A number of oil rich nations individually and collectively have begun to assist the non-oil rich nations in their efforts to survive increased oil prices. In particular the Saudis have been concerned with increasing world food output. As such these sources offer possibilities for developing food and energy related projects in the developing nations, particularly the Moslem nations which form a major block of South and Southeast Asia and Africa. This proposal has the advantage of external funding of the project but the disadvantage of requiring a means of entering the project schedule of the Saudis or other potential donor.

\section{Energy Technical Training Program.}

Many of the developing nations are sending representatives to programs such as the Brookhaven Energy Management Program at which the new technologies are being presented. Additional effort could be placed on presenting photovoltaics as a viable option for specific applications in the nations. Demonstrations of hardware and discussion of successful applications in other nations could greatly enhance the value of the presentation and training.

Grass roots agency development and implementation program.

There exist in the United States and in many of the developed nations voluntary agencies in operation at the village level in the developing nations. While these agencies receive a portion -- sometimes nearly all -- of their funding from governmental sources they perform their most significant function at the village level. Such agencies as Oxfam, CARE, and Catholic Relief Services to name only three have extensive staff operations and are frequently in a position to experiment with new techniques or technologies. It was unclear in the workshop what specific information would be required by the program officiers of such an agency but it was suggested that they be approached for both interest and for a definition of their needs in order to experiment with or introduce such systems for irrigation or for village electrification through their agency wings in country. 
Staged industry systems development and deployment.

There was considerable discussion throughout the workshop of the immaturity of the photovoltaics industry as it presently exists in entering a developing nation market. Workshop participants were not enthusiastic about suggestions of a program to subsidize joint venture marketing activities in an effort to team a U.S. photovoltaic manufacturer with an incountry distributor because they felt that such a team would still not be able to break into the market at the governmental level where one could generate a demand rather than merely discuss a need. To offer an alternative it was suggested that there be a staged program to involve present photovoltaics manufactures in systems development for developing nations applications followed by assisted depolyment of test systems in specific locations. The three states of the proposal would be the following:

STAGE ONE: Issue an RFP for the development of nation or reyion specific applicalions for photovoltaic power systems which take into consideration first needs for which photovoltaics will have a market edge arid second demands, i.e. areas in which funding for such an application would be forthcoming from within internal national funding or from international agencies. Such an efforl. would not be long in duration but would require a contractor who was knowledgeable in energy requirements in the developing nations not one who was knowledgeable in photovoltaics.

STAGE TWO: Issue RFPs or PRDAs for the development of systems which could be applied to the application requirements listed above. Here the need would be to develop systems aimed at specific geographic areas of specific generic markets in order for the contractors to develop system experience in meeting the engineering requirements of a specific application. The emphasis here must be upon engineering efficiencies and cost thus calling for cleverness in design with an eye to marketing of the projert -- and possible assembly -- within a specific geographic region.

STAGE THREE: Given a set of surcsssful syetems dezigns, lher next stage shiml! be the incountry insldilation of a set of systems in conjunction with an incountry participant either a distributor or a manufacturer. The effort here is threefold. First testing of the equipment, second development of experience on the part of the U.S. supplier in dealing with the intricacies of developing nations and third, the development of an indigenous supply/ marketing/manufacturing capability which is critical to the eventual marketability of any device in the developing nations.

There are two points which came out in the discussion which do not fit well into the summary above but rather cut arross all of the discussioll. The first deals with the cost decline curve for photovoltaic hardwars. The second deals with the nature of the good itself.

It was suggested that the photovoltaic hardware will be declining in cost over the next decade. Many of the participants saw this as a major selling point for the technology in discussions with the developing nations. The position of the U.S. may be one of offering a subsidy for the power system in response to a future decline in price. Under these circumstances it is possible for the nations or agencies to put photovoltaic power systems on equal footing with their alternatives and place photovoltaic systems into applications' which will be cost effective in the near future rather than the present. 
The second point was raised by several participants with extensive experience in both the politics of the developing nations and the rural energy environment. It was pointed out that providing power or water was long seen as a political/economics means of controlling populations. Having electricity in Indonesian villages was something that was handed out by the central government. A diesel engine generator set represented a large block of capital to the villagers but they had to struggle mightily to pay for the maintenance and for the fuel to keep the generator in operation. While the gift was large it none the less carried a cost with it. Much the same argument was made for the provision of water pumps in Bangladesh. The pump was provided by the government but the farmer(s) provided the fuel and the maintenance. Again, a large gift with a real upkeep cost. Photovoltaics represents a greater gift because there is no or little maintenance and no fuel cost. As a result the technology represents, within the rural power s.ystem a means of influencing even more than before the social structure of the area and of benefitting the larger farmer to the detriment of the smaller, or of rewarding the loyal region to the detriment of that of the opposition. While it is not possible for a plan such as that under development to consider all problems such as these in the design of the plan, the nature of the technology requires that these considerations be recognized and that their potential social impacts be noted.

In summary, the workshop attempted to present a view from the developing nations on the likely acceptance of photovoltaics and the channels for introduction of the technology. It was not believed that the technology could be marketed directly as it was not a good bought and sold, but one component of a system to perform a specific function such as pumping water. With this caveat in mind, the workshop pointed to a number of alternative pathways for influencing aid giving agencies to include photovoltaic systems in their development projects. 
MEETING ATTENDEES July 9, 1979 Photovoltaic International Plan

John Briscoe, Harvard University

Paul Carpenter, Jet Propulsion Laboratory

Dennis Costello, Solar Energy Research Institute

Russell delucia, Meta Systems, Cambridge, MA

Thomas Klein, M.I.T.

Thomas Kef, M.I.T.

Lewis Perelman, Jet Propulsion Laboratory

Peter Rogers, Harvard University

Douglas V. Smith, Consultant

Alan Stroud, Consultant (M.I.T.)

Richard Tabors, M.I.T.

134 


\author{
PHOTOVOLTAIC INTERNATIONAL PLAN \\ CAMBRIDGE REVIEW MEETING \\ JuTy 9, 1979 \\ 10 AM to 3 PM
}

PURPOSE: Discuss preliminary structure of photovoltaic international plan, including justification for U.S.D.0.E. involvement and al ternative strategies for plan implementation.

Review avenues for acceptance of U.S. manufactured/non U.S. manufactured photovoltaic power systems within developing nations with particular attention to the alternative financing, amnufacturing, and marketing structures available and to alternative means of developing test and demonstration programs.

The following set of questions are presented to offer areas of consideration. They are not intended to be all inclusive but rather to offer points of departure for the discussion.

Role of Photovoltaics in development:

- Is there a market for photovoltaics in the developing nations? If so, where, how large in what types of applications?

- What are the economic market constraints?

- What are the financial market constraints?

- What are the physical/infrastructure constraints?

- How do (do) photovoltaic power systems fir into the development requirements of the nations themselves?

U.S. Government involvement:

- Should the U.S. Government be actively involved in the support of U.S. manufactured photovoltaic power systems in the developing nations? direct support to manufactures indirect support through licensing indirect support through embassy assistance indirect support through R\&D efforts inside of the United States no direct of indirect support

Agency/private sector involvement:

- What agencies of the U.S. Government or other multilateral groups would lead or be involved in a photovoltaics development effort?

USDOE

USAID

IBRD

UNDP or UNIDO or UNEP

- What are the options open for alternative forms of involvement by the private sector?

Sales only

Joint Venture activities ranging from marketing through full manufacture

In country licensing agreements 
- What are the constraints to private sector involvement and their means of reducing/eliminating these constraints?

LDC Response:

- What are the likely responses of developing nations to the introduction of a high technology energy source such as photovoltaics?

- Does the type of response vary by level of development, by level of industrialization, by agricultural structure, etc?

If there is to be a federal DOE program:

- What are the planning options, i.e., should the effort be sectorally specific -- agriculture or rural electrification -- or should the program be region specific -- Asia or Africa.

- What levels of funding would be required and how much is too much?

- What type of cooperative, interagency relationships are both necessary and possible?

Testing and demonstration activite.s:

- Should tests and demonstrations be related to efforts to promote U.S. industries in the developing nations?

- What is a "good" demonstration project in a developing nation context?

- Where are the pitfalls and how (if) can they be avoided or minimized?

- What is the correct level of monitoring and evaluation and in what areas -social

technical

economic 


\section{H.2 Photovoltaics in the Third World}

prepared by Douglas Smith

Dramatic increases in world oil prices, food shortages, the environmental and economic consequences of firewood shortage, and the universal demise of the nuclear dream have underscored the need for new approaches to energizing the world's villages. New energy must focus on need rather than consumption demand of the rich, utilize the local renewable energy resource: the sun, and have low maintenance requirements. For some of the most urgent of village needs: water lifting for human and animal consumption, irrigation, and powering of small agricultural machinery such as rice mills and cotton gins, photovoltaics appear well suited because of their zero fuel requirements, negligible electrical storage requirements, low maintenance, long life, modularity, and benign environmental impacts.

The expense of photovoltaics, an expense that is nearly 100 percent front-end costs, represents a powerfut barrier to acceptance. Rising oil prices, however, have made petroleum-based village energization an even more elusive goal for the hundreds of millions of the world's rural poor while costs of photovoltaics continue to decline even more rapidly than predicted by official sources. This paper attempts to estimate when photovoltaics systems will compete cost-effectively in those Third World applications of most importance to village development.

Two earlier papers (Smith, 1977, and Smith and Allison, 1978) have discussed in some detail several Third World applications of photovoltaics. This paper reviews and updates the conclusions of earlier work within the context of the international plan documentation called for under PL 95-590. Although the most recent equipment prices, 
efficiency estimates, and operation and maintenance costs are employed in this paper, the most striking change since the 1977 paper has been fuel prices. For all applications, photovoltaics look even more attractive now in the rural Third World than they did as recently as early 1977. The analyses and conclusions presented here are conservative--further revision in the future will paint an even brighter future of photovoltaics' prospects.

Comparisons of photovoltaic costs with costs of the least-cost, conventional alternative are performed for the following cases:

a) 5 horsepower diesel irrigation pump or agricultural processing machine,

b) 1 horsepower gasoline water supply pump,

c) 500 watt gasoline generator for educational television and a few radios and lights,

d) 12.5 kilowatt diesel generator for village electrification, and

c) 250 watl ilicro-irrigation pump.

These five applications cover the range of rural Third World power requirements, excluding the very small communications applications that do not contribute dirertity tọ rural wall-bcing. If photovollaics can compete in any or all of these markets, their future in the new sutar world is ensured. By computing the annual cost of performing the desired task by conventional means, then computing the annual cost of performing the same task with photovoltaics (together with the requisite power conditioning and storage devices), it has been possible to determine the "breakeven cost" of solar arrays. This is the cost, in early 1979 dollars, at which photovoltaics become cost effective compared to the 
least-cost conventional alternative. As will be seen, for all five applications, breakeven costs are those projected by DOE for the early 1980 's.

a) 5 horsepower irrigation pump, rice mill, cotton gin, sugarcane crusher, flour mill, oil press, or other crop processor.

Elsewhere the use of photovoltaics with a 2 cusec or $200 \mathrm{~m} 3 /$ hour low-lift ( 4 meters) pump in the. Lake Chad polders has been analyzed. (See D. V. Smith, 1977.) Such an installation would use a 5 horsepower engine. Also analyzed were a similar sized pump on a tubewell in the Pakistan Punjab (100 $\mathrm{m}^{3} /$ hour, 8 meter total life, 5 horsepower) and on a river in Bangladesh ( $200 \mathrm{~m} 3 /$ hour, 4 meter lift, 5 horsepower). The earlier report detailed the implications for photovoltaics use of different solar and crop irrigation regimes. That report also analyzed a 5 horsepower rice huller (0.2 tons per hour) which can be considered typical of agricultural processing machinery.

Table 1 lists the assumptions used in assessing the cost-effectiveness of replacing 5 horsepower diesel engines in remote areas of the Third World where fuel and maintenance costs are high. For further detalls see the 1977 report. All costs and performance specifications have been updated based on July 1979 distributors' quotes.

Diesel costs will be calculated using two alternative fuel prices: $\$ .35 / 1$ iter (\$1.32/gallon) and \$.50/liter (\$1.89/gallon.). The July 31 , 1978, price of diesel fuel in Kenya (urban) was \$.33/liter. Local delivery costs to remote villages can easily increase this to merely $\$ .50 /$ liter. Recent reports indicate diesel fuel prices in Ouagadougou, Upper Volta, are already in excess of $\$ .50 / 1$ iter so these costs are not the highest that could be used. 
Table 1: 5 Horsepower Pump and Rice Mill - Assumptions

Diesel engine

life: 8 years

fuel consumption: 0.31 liters/hp-hour cost: $\$ 1400$ including 12 percent spares

maintenance and lubrication oils: $\$ .73$ per operating hour

Photovoltaic system

i) DC permanent magnet motor, brushless

life: 12 years

efficiency: 75 percent

cost: $\$ 300$ including 12 percent spares

mafintenance: $\$ 30$ per year (10 percent)

ii) Max Imum power tracker

Tife: 12 years

efficiency: 90 percent

cost: $\$ 30$ for brain and $\$ 500$ for DC/DC converter

maintenance: $\$ 53$ per year (10 percent)

iii) Solar arrays

life: 10 years for arrays; 20 years for structure

cost: 75 percent array; 25 percent structure including

spares and installation

maintenarice: $\$ 30$ per year (local labor)

Both systems

hours of operation: 1000 hours per year

rice hulled: 200 tons per year (200 hectane worth at one ton per hectare)

water pumped: 200,000 $\mathrm{m} 3$ per year in Chad and

Bangladesh; 100,000 in Pakistan

area irrigated: 13.8 hectares of wheat/cotton rotation

in Chad; 20.1 hectares of boro rice or 49.4 hectares

of wheat in Bangladesh; 5.9 hectares of wheat/cotton in Pakistan 
The annual cost of the diesel system is (see Table 1 for ass umptions):

$$
\begin{aligned}
& \text { capital cost }=1400 \mathrm{R}(10.8)=\$ 262 \\
& \text { maintenance }=1000 \times .73=730 \\
& \text { fuel }=.31 \text { liter } / \mathrm{hp}-\mathrm{hr} \times 1000 \text { hours } \times 5 \mathrm{hp} \times .35 / 1=543 \\
& \text { or } .31 \text { liter } / \mathrm{hp}-\mathrm{hr} \times 1000 \text { hours } \times 5 \mathrm{hp} \times .50 / 1=775 \\
& \text { Total }=\$ 1535 \text { for fuel price of } \$ .35 / 1 \text { iter } \\
&=\$ 1767 \text { for fuel price of } \$ .50 / 1 \text { iter }
\end{aligned}
$$

The annual cost of the solar system is, where $S$ is the installed cost of solar arrays per peak kilowatt:

$$
\begin{aligned}
& \text { capital cost }=30 R(10,12)+5.5 S[.75 R(10,10)+.25 R(10,20)] \\
& \text { maintenance }=: 83+30=113 .
\end{aligned}
$$

Solving for $S_{e}$, the breakeven cost of installed arrays, including structure cost: for diesel price of $\$ .35 /$ liter, $\mathrm{S}_{\mathrm{e}}=1707$ which is equivalent to $\$ 1.28$

$$
\begin{aligned}
& \text { per watt for arrays (1981 goal) } \\
& \text { for diesel price of } \$ .50 / 1 \text { iter, } S_{e}=1986 \text { or } \$ 1.49 \\
& \text { per watt for arrays (1983 goal) }
\end{aligned}
$$

Either diesel or solar can improve their competitive positions if they are used more than 1000 hours per year. In theory, the solar engine could be used more than twice as many hours, the diesel engine more than eight times. In practivc, significantly greater utilization rates are not usually achieved because of the seasonal nature of agricultural 
activities and diseconomics of scale caused by small landholdings, plot fragmentation, and difficulties of cooperative organization under semi-feudalism and nascent capitalism. If both systems were used for 1800 hours at a diesel price of $\$ .50 /$ liter, breakeven array cost would be $\$ 2.57 /$ watt.

Maintenance costs given in Table 1 for diesel are high, but based on experience in countries like Chad. They are several times too high for India but would bẹ lnw for remote diesels maintained by labor paid at U.S. rates.

b) 1 horsepower water supply pump

A critical need in many of the world's villages is safe, reliable drinking water. A typical village of 500 persons and 150 cattle and buffalo will need 20 liters/person/day for domestic purposes and $\mathbf{4 0}$ liters/animal/day for livestock or a total of $16 \mathrm{~m} 3 /$ day: $4 \mathrm{~m} 3 /$ hour if pumping proceeds for four hours. With a 30 meter pumping head (including 5 meters to storage tank), 50\% pumping efficiency, 63 percent motor/power conditioner efficiency, one kilowatt will be required. Table 2 lists relevant assumptions.

The annual rost of the gasoline system is:

$$
\begin{aligned}
& \text { capital cost }=150 R(10,3)=\$ 60 \\
& \text { matntellarice }=60 \\
& \text { fuel }=.47 \text { liters } / \text { hour } \times 1440 \text { hours } \times \$ .35 / 1=237 \\
& \text { or } .47 \text { liters } / \text { hour } \times 1440 \text { hours } \times \$ .50 / 1=338 \\
& \text { Total }=\$ 357 \text { for fuel price of } \$ .35 / 1 \text { iter } \\
&=\$ 458 \text { for fuel price of } \$ .50 / 1 \text { iter }
\end{aligned}
$$


Table 2: 1 Horsepower Water Supply System Assumptions

Gasol ine engine

life: 3 years

fuel consumption: 0.47 liters/hp-hour (50 percent greater than diesel engine) cost: $\$ 150$ inclucing spares

maintenance: $\$ 60$ per year

\section{Photovoltaic system}

i) DC motor

life: 12 years

efficiency: 70 percent

cost: $\$ 200$ including spares

maintenance: $\$ 20$ per year (10 percent)

ii) Maximum power tracker

life: 12 years

efficiency: 90 percent

cost: $\$ 30$ for brain and $\$ 100$ for $D C / D C$ converter

maintenance: $\$ 13$ per year (10 percent)

iii) Solar arrays

life: 10 years for arrays; 20 years for structure

cost: 75 percent array; 25 percent structure including

spares and installation

maintenance: $\$ 30$ per year (local labor)

\section{Both systems}

hours of operation: 4 hours per day; 1440 hours per year water pumped: $16 \mathrm{~m} 3 /$ day for 500 persons, 150 cattle pumping efficiency: 50 percent

pumping head: 30 meters (including 5 meters to storage tank) 
The annual cost of the solar system is:

$$
\begin{aligned}
& \text { capital cost }=330 R(10,12)+S[.75 R(10,10)+.25 R(10,20)] \\
& \text { maintenance }=33+30=63 \\
& \text { Solving for breakeven cost, } S_{e} \text { : }
\end{aligned}
$$

$$
\begin{gathered}
\text { for diesel price of } \$ .35 / \text { liter, } \mathrm{S}_{\mathrm{e}}=1626 \text { or } \\
\$ 1.22 \text { per watt for arrays }(1984 \text { goal) } \\
\text { for diesel price of } \$ .50 / 1 \text { iter, } \mathrm{S}_{\mathrm{e}}=2295 \text { or } \\
\$ 1.72 \text { per watt for arrays (1983 goal) }
\end{gathered}
$$

It should be noted that only four hours per day of operation is assumed. Most places in the Third World have sifficient solar radiation to operate photovoltaics more than 4 hours so there can be some reduction in array requirements.

c) 500 watt gasoline generator for educational television, radios, and lights.

Educational television and radio and schoolhuuse and meeting plate lighting can serve useful community functions. In many countries a small generator provides sufficient power to run a TV (60-160 watts usually) and a few lights ( 15 watt fluorescent lights are a goud possibility for energy efficiency).

A 500 watt generator rarely bears a load of 500 watls but it will be assumed here that a 500 watt solar capability is required. Energy loss in the battery system is matched by arrays being able to generate power on the average more than four hours per day: in many places 6-7 hours per day in fact. 
Water pumping systems did not require battery storage because water can be stored. TV and lights, however, will be used at night so electricity storage is needed. Ten days minimum is provided but because it is not anticipated that a full load of 500 watts will be borne for four hours, there will in fact be storage available for a considerably longer period. See Table 3 for further assumptions.

The annual cost of the gasoline generator is:

$$
\begin{aligned}
& \text { capital cost }=440 \mathrm{R}(10,3)=177 \\
& \text { maintenance }=60 \\
& \text { fuel }=.67 \mathrm{liter} / \text { hour } \times 1440 \text { hours } \times \$ .35 / 1=338 \\
& \quad \text { or } .67 \text { liter/hour } \times 1440 \text { hours } \times \$ .50 / 1=482
\end{aligned}
$$

The annual cost of the solar system is:

$$
\begin{aligned}
& \text { capital cost }(75 \times 20) R(10,6)+S[0.375 R(10,10)+.125 R(10,20)] \\
& \text { maintenance }=(20 \times 5)+30=130
\end{aligned}
$$

Solving for breakeven cost, $S_{e}$ : for diesel. price of $\$ .35 / 1$ iter, $S_{e}=1329$ or $\$ 1.00$ per watt for arrays (1984-5 goal); for diesel price of $\$ .50 /$ liter, $\mathrm{S}_{\mathrm{e}}=3231$ or $\$ 2.42$ per watt for arrays (1982 goal).

It should be emphasized that battery costs account for over half the total for this photovoltaic system. Less storage, lower cost of batteries (DOE has a $\$ 50 /$ kWh cost goal), or lower maintenance cost assumptions will improve the outlook for photovoltaics considerably. For instance, batteries at $\$ 50 / \mathrm{kWh}$ and no maintenance (permanently sealed) increase the breakeven cost of arrays to $\$ 4.55$ per watt $(1980-1$ goal) at a gasoline price of $\$ .50 /$ liter. 
Table 3: 500 Watt Generator - Assumptions

Gasol ine generator

life: 3 years

fuel consumption: 0.67 liters!hour (reported by Weiss/and Pak, IBRD, Honda generator)

cost: $\$ 440$ including spares

maintenance: $\$ 60$ per year

\section{Photovoltaic syslein}

i) batteries

life: 6 years

cost: $\$ 75 / \mathrm{kWh}$

efficiency: 85 percent

maintenance: $\$ 5 / \mathrm{kWh}$

storage capacity: $20 \mathrm{kWh}(.5 \mathrm{~kW} \times 4$ hours/day $\times 10$ days minimum)

ii) solar arrays

life: 10 years for arrays; 20 years for structure cost: 75 percent array; 25 percent structure including spares and installation

maintenance: $\$ 30$ per year (local labor)

\section{Both systems}

hours of operation: 4 hours per day; 1440 hours per year 
It should also be noted that if power will in fact only be demanded four hours a day, the photovoltaic system is oversized at 500 watts. In a place with an average insolation of $5.5 \mathrm{kWh} / \mathrm{kW} /$ day only $(500 / .85 \times$ $(4.55)=430$ watts peak is needed. This argument cuts both ways, however, because when required the gasoline generator can more easily provide power more than four hours per day without storage depletion.

In some situations; e.g., in ETV systems in Malaysia as described in Weiss and Pak, a 500 watt generator is used only to power a 67 watt television. In such a situation the generator is obviously oversized and photovoltaics look more attractive if sized to match the 67 watt need. In this case, with a battery efficiency of 85 percent and a matching between solar insolation and hours of use, an array of 80 watts would be needed. Breakeven (costs will be $\$ 26.86$ for fuel price of $\$ .35 /$ liter. Photovoltaics shine brightest where there is in present practice a clear mismatch between power source and power use.

d) $12.5 \mathrm{~kW}$ village electrification

Conventional village electrification is accomplished ordinarily by a diesel generator or grid connection. Table 4 describes some features of a typical Gangetic Plain village. Electrification would provide:

i) potable water supply $1 \mathrm{~kW}$

ii) rice mill $5.5 \mathrm{~kW}$

iii) TV, lights, radio $1 \mathrm{~kW}$

iv) other village loads $5 \mathrm{~kW}$

Table 5 lists the assumptions for a comparison between providing this power by diesel and by photovoltaics. The annual cost of diesel generation is:

$$
\text { capital cost }=5500 R(10,8)=\$ 1031
$$


Table 4: Typical Third World Village (Gangetic Plain)

$\begin{array}{ll}\text { population } & 500 \\ \text { families } & 110 \\ \text { cattle } & 150 \\ \text { area cultivated } & 200 \text { hectares (1) } \\ \text { depth to water } & 10 \text { meters (1) } \\ \text { solar insolation } & 5.1 \mathrm{kwh} / \mathrm{m} 2 / \text { day (1) } \\ \text { rainfall } & 100 \mathrm{centimeters} \mathrm{(2)} \\ \text { food grain yield } & 1 \text { ton per hectare }\end{array}$

(1) This is low compared with other parts of the Third World

(2) This is high compared with other parts of the Third World Note: See D. V. Smith, 1977, for more detail

Table 5: $12.5 \mathrm{~kW}$ V1llage Eleclrification - Assumptions Diesel generator

lire: 8 years

fuel consumption: 4.73 lilers/huur (iejpurted by Mubayi, $B N L$, for Witte generator)

cost: $\$ 5500$ including spares

maintenance: $\$ .73$ per operating hour

distribution lines: $3 \mathrm{~km}$ at $\$ 4500 / \mathrm{km}$ (IBRD); 20 year life; $\$ 675$ maintenance

Photovoltaic system

i) batteries (for TV, lights, radios: $1 \mathrm{~kW}$ )

i) batteries

life: 6 years

cost: $\$ 75 / \mathrm{kWh}$

efficiency: 85 percent

maintenance: $\$ 5 / \mathrm{kWh}$ 
Table 5: $12.5 \mathrm{~kW}$ Village Electrification - Assumptions (continued) storage capacity: $400 \mathrm{kWh}$ ( $1 \mathrm{~kW} \times 4$ hours/day $\times 10$ days minimum)

ii) maximum power trackers (for water pumps, rice mill, other applications: $11.5 \mathrm{~kW}$ )

life: 12 years

efficiency: 90 percent

cost: a) water pump 130

b) rice mill 530

c) 2 other applications totaling $5 \mathrm{~kW} 560$

maintenance: $\$ 122$ per year (10 percent)

iii) DC motors

life: 12 years

efficiency: 70 percent

cost: a) water pump 200

b) rice mill 300

c) 2 other applications, 2.5KW each 500

maintenance: $\$ 100$ per year (10 percent)

iv) Solar arrays

life: 10 years for arrays; 20 years for structure

cost: 75 percent array; 25 percent structure including

spares and installation

maintenance: $\$ 30$ per year (local labor)

Both systems

hours of operation: 4 hours per day, 1440 hours per year water pumped: $16 \mathrm{~m} 3 /$ day for 500 persons, 150 cattle

rice hulled: 200 tons per year

ETV and lights to maximum of $1 \mathrm{~kW}, 4$ hours per day

$5 \mathrm{~kW}$ for other village uses 


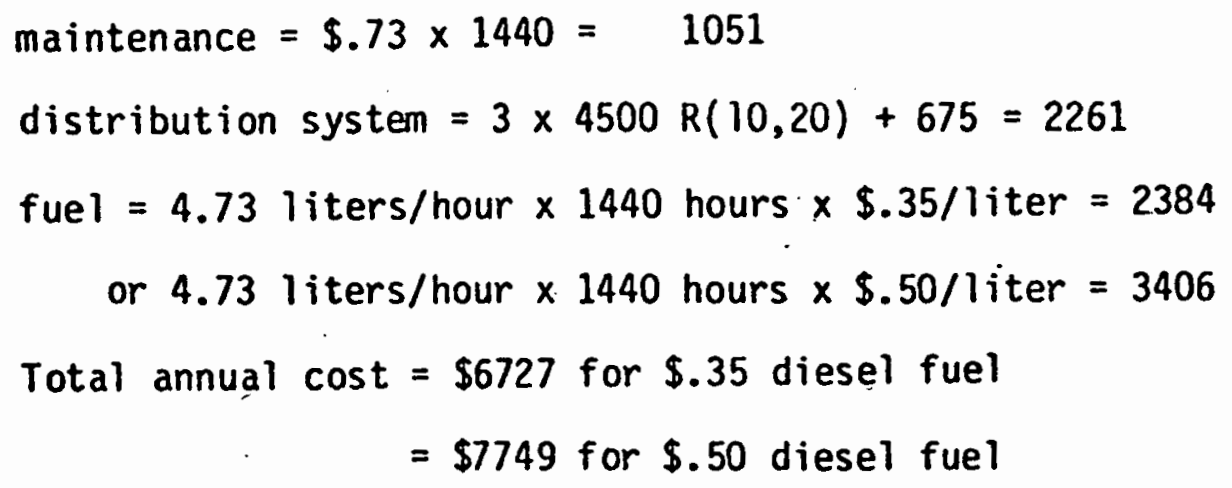

The annual cost of the solar system is:

$$
\begin{aligned}
& \text { capital cost }=(40 \times \$ 75) R(10,6)+2220 R^{\prime}(10,12) \\
& +12.5 S[0.75 R(10,10)+0.25 R(10,20)] \\
& \text { maintenance }=\$ 222+30=\$ 252 \\
& \text { Solving for breakeven cost, } S_{e}: \\
& \text { for diesel price of } \$ .35 / 1 i t e r, S_{e}=2885 \text { or } \\
& \quad \$ 2.16 \text { per watt for arrays }(1982 \text { goal) } \\
& \text { for diesel price of } \$ .50 / 1 i t e r, S_{e}=3425 \text { or } \\
& \quad \$ 2.57 \text { per watt for arrays }(1981-2 \text { gnal) }
\end{aligned}
$$

If grid extension is short enough, that, rather than diesel generation, is the relevant alternative. Table 6 lists assumptions regarding grid extension. If diesel fuel costs $\$ .50$ per liter, grid extension under these assumptions is ecuriomical only if the. sub-transmission line distance is less than 5 kilometers. (If diesel fuel costs $\$ .35$ per liter, line distance would have to be less than 3.5 kilometers.), 
Table 6: Grid Extension Assumptions

Cost of energy at existing grid: $\$ .10 / \mathrm{kWh}$ (India)

cost of grid extensions: $\$ 4500 / \mathrm{km}$ (IBRD)

kWh consumed: $12.5 \mathrm{~kW} \times 1440$ hours

$$
=18000 \mathrm{kWh}
$$

distribution lines: $3 \mathrm{~km}$ at $\$ 4500 / \mathrm{km}$

life: 20 years

maintenance: 5 percent of capital cost 


\section{e) 250 watt micro-irrigation}

For a complete discussion of this application of photovoltaics the reader is referred to Smith and Allision; 1978. The argument presented there is that a need of immense proportions exists for an irrigation unit that is designed for small plots of approximately an hectare and for low heads (up to 5 meters), that is low in maintanance requirements and suitable for use by the millions of small farmers in the world's sunny deltas. No fossil fuel or grid-connected alternatives now match this need: grid-connection is too inflexible and costly for small plots and diesel pumps are not available in small enough sizes. As a consequence, a farmer uses human or animal power or does not irrigate when land holdings are small and cooperation is infeasible.

Table 7 describes the assumptions used to analyze photovoltaic micro-irrigation: Such a 250 watt $(1 / 3$ horsepower, $9 \mathrm{~m} 3 /$ hour at 4.5 meter head) system has an annual cost of $\$ 240$ if photovaltaic arrays cost $\$ 2.80 /$ peak watt: the cost goal with current technology.

Such a system can irrigate 0.67 ha. rice within a 4.5 meter lift or 1.25 ha. wheat, or 2 ha. rice with a 1.5 meter lift or 3.75 ha. wheat. For rice, irrigation should allow a production increase worth about $\$ 250 /$ hectare/hear (2.5 tons/hectare increase at $\$ 100$ per ton). Therefore, at a solar array cost of $\$ 2.80 /$ watt, a rice farmer breaks even lifting from 3 meters. Any less lift and profits flow. For wheat and similar productivity assumptions, the breakeven lift is 5.6 meters. 
Table 7: 250 Watt Micro - Irrigation - Assumptions Photovoltaic system

i) pump/well ( $40 \mathrm{gpm}$ at 4.5 meters)

life: 8 years

cost: $\$ 225$

maintenance: $\$ 22$ per year

ii) DC permanent magnet motor $(1 / 3 \mathrm{hp})$

life: 12 years

cost: $\$ 80$

maintenance: $\$ 8$ per year

iii) Maximum power tracker (250 watt)

life: 12 years

cost: $\$ 30$ for brain and $\$ 30$ for converter

maintenance: $\$ 6$ per year

iv) Solar arrays

life: 10 years for arrays; 20 years for structure

cost: 75 percent array; 25 percent structure including

spares and installation

maintenance: $\$ 30$ per year (local labor)

v) System

efficiency: 45 percent

solar insolation: 4.8 watt-hours/peak watt/day

heads: 1.5 meters and 4.5 meters

crops: rice or wheat 
Table 8: Summary of Breakeven Costs of Solar Arrays (\$ watt peak)

Application6

(a)

diesel irrigation

(b)

gasol ine water supply

(c)

gasoline generator

for TV
1.22

1.00

.35

1.28

$(26.86)^{2}$

Power

.50

$5 h p$

(2.57)1

$\cdot 1.72$

1hp

2.42

$500 \mathrm{w}$

(d)

$2.16^{4}$

2.575

$12.5 \mathrm{kw}$

diesel electric

generator for village

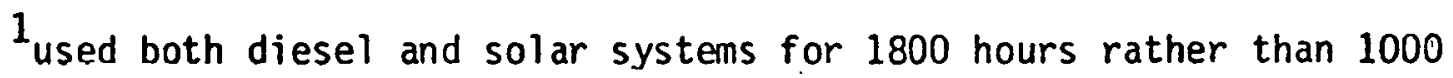

2 installation of photovoltaics to meet sole demand of $67 \mathrm{w}$ TV

3 batteries at $\$ 50 / \mathrm{kwh}$ and no maintenance

4 max. grid extension $3.5 \mathrm{~km}$

$5_{\text {max. grid extension } 5 \mathrm{~km}}$

6 for application (e), 250 watt micro-irrigation, breakeven pump lift for $\$ 2.80 /$ watt array cost and rice is 3 meters; for wheat is 5.6 meters 
Summary and Conclusions

Table 8 summarizes breakeven costs for the above applications. Breakeven costs for fuel prices of $\$ .35$ and $\$ .50$ per liter are exhibited. Breakeven costs are in early 1979 dollars and are for solar arrays (assumed to be 75 percent of the solar system cost exclusive of power conditioning, batteries, and motors).

For comparison, a 1979 solar array cost of $\$ 2.80 /$ watt peak is assumed by DOE to be attainable with current technology by 1981 .

The first line of Table 8 indicates the breakeven cost of solar arrays for a 5 horsepower diesel irrigation system, or diesel rice or flour mill, operating 1000 hours per year is about $\$ 1.50$ per peak watt if diesel fuel costs $\$ .50$ per liter as it already does in many isolated Third World villages. This breakeven cost would be even higher if:

i) the diesel and solar systems operate more hours ( $\$ 2.57$ per peak watt for 1800 hours and $\$ .50$ per liter);

ii) diesel fuel were more expensive than $\$ .50$ per liter;

iii) cropping intensities were higher than, for example, the cotton/wheat assumed for Chad, say wheat/cotton/fodder;

iv) solar arrays were used for cotton ginning and flour milling when not required to pump water;

v) diesel engines smaller than 5 horsepcwer are being replaced by photovoltaics, in which case diesel maintenance costs look even larger compared to solar; or

vi) pumping head were less (as in $v$ because of the economies of scale of diesel diesel engines).

The second line of Table 8 summarizes the breakeven costs of solar arrays used to replace a one horsepower water supply pump. For $\$ .50$ per 
liter gasoline, the breakeven solar array cost is approximately $\$ 1.75$ per peak watt--a cost goal for 1983 . It should be noted that, compared to the 5 horsepower diesel system, this one horsepower water pumping system is more affected by increases in fuel prices because of the relatively low cost of the gasoline engine compared to fuel costs.

The third line of Table 8 , a 500 watt system, illustrates sensitivity of solar array breakeven costs to fuel prices most dramatically. If gasoline is $\$ .35 / 1$ iter, breakeven cost is $\$ 1.00$ per peak watt; but if gasoline is $\$ .50 / 1$ iter, breakeven costs soars to $\$ 2.40$ per peak watt.

If solar arrays are used solely to power a 67 watt educational television, and gasoline is $\$ .35$ per liter, breakeven cost is $\$ 27$ per peak watt. This explains why solar-powered ETV systems already exist in several countries.

The impact of early achievement of DOE battery cost goals is also illustrated for the 500 watt system. Battery costs of $\$ 50 / \mathrm{kWh}$ (instead of the assumed $\$ 75 / \mathrm{kWh}$ requiring little or no maintenance raise the solar array breakeven cost from $\$ 2.42$ to $\$ 4.55$ with a $\$ .50$ per liter. gasoline price. This is practically achievable now from the photovoltaic side but not from the battery side.

The fourth line summarizes results for a $12.5 \mathrm{~kW}$ village generator comparing three systems:

1) a $12.5 \mathrm{~kW}$ Witte diesel generator with village distribution system,

2) extension of an existing power grid, and

3) a modular solar system consisting of:

i) $1 \mathrm{~kW}$ potable water system, 
ii). $5.5 \mathrm{~kW}$ rice mill,

iii) $1 \mathrm{~kW}$ distributed arrays for lights, TV, and radios, and iv) two $2.5 \mathrm{~kW}$ separated loads.

Breakeven solar array cost is above $\$ 2.50$. when diesel fuel is $\$ .50$ per liter. This puts the village electrification market nearly within the range of current photovoltaics technology provided grid extension exceeds 5 kilometers.

The final application, 250 watt micro-irrigation, is reported in a different manner. It is shown that, for a solar array cost of $\$ 2.80$ per peak watt, it is profitable for a farmer to use such a system to irrigate rice if the pumping lift does not exceed three meters or to irrigate wheat if the lift does not exceed 5.6 meters. Even at current solar array prices, low lift pumping with small photovoltaic pumps is a profitable venture provided financing is made available. There is no fossil fuel alternatuve to these micro-irrigation pumps: the alternatices are human, animal, or wind power, all of which are generally, more expensive than photovoltaics for new systems.

It is therefore striking that with the most likely assumptions breakeven costs lie between $\$ 1.00$ and $\$ 2.57$ for the first four applications. In other words, even with fuel prices of $\$ .50 /$ iter, some improvement in array costs beyond the $\$ 2.80$ achievable with current technology will be needed to be competitive in any of these Third World markets. Once costs below $\$ 2$ are achieved, markets open up rapidly. 


\section{References}

Lysen, Erik, H., "Solar Pumps: A Glance at their Economics and Availability," Wind and Sun Compendium, Stichting TOOL, Amsterdam, Netherlands, no. 5, April 1979, pp. 4 - 11.

Matlin, R. W., "Design Optimization and Performance Characteristics of a Photovoltaic Microirrigation System for Use in Developing Countries," M.I.T. Lincoln Laboratory, May 1979.

Mubayi, Vinod and Tien Le, "Irrigation in Less Developed Countries: A Study of the Comparative Costs of Using Conventional and Renewable Energy Sources for Powering Small Irrigation Pumps in Develuping Countries," Brookhaven National Lahoratory, March 1977; draft.

Pacific Nurlliwest Laboratory, "Export Potential for Photovoltaic Systems," April 1979.

Rosenblum, Louis et al, "Pliuluvoltaic Village Power Application: Assessment of the Near-Term Market," NASA -Lewis, January 1978.

Rosenblum, Louis et al., "Photovoltaic Power Systems for Rural Areas of Developing Countires," NASA-Lewis, May 1979.

Smith, Douglas V., "Photovoltaic Power in Less Veveloped Countries," M.I.T. Lincoln Laboratory, March 1977.

Smith, Douglas V. and Stephen V. Allison, "Micro Irrigation with Photovaltaics," M.I.T. Energy Laboratory, April 1978.

Tabors, Richard D., "The Economics of Water Lifting for Small Scale Irrigation in the Third World: Traditional and Photovoltaic Technologies," M.I.T. Energy Laboratory, May 1979.

Usmani, I. H., "Energy Banks for Small Villages," Bulletin of the Atomic Scientists, June 1979, pp. 40-44.

Weiss, Char Tes and Simon Pak, "Developing Country Applications of Photovoltaic Cells," World Bank Science and Technology Report no. 7, January 1976. 
H. 3 PHOTOVOLTAICS IN THE THIRD WORLD: PRIORITIES OF CONSUMING COUNTRIES CONCERNING COMMERCIALIZATION

by

Thomas P. Klein 


\subsection{Introduction}

Numerous recent studies have drawn the conclusion that the developing countries of the world represent a potentially enormous near-term market for photovoltaic power.1 While a number of smaller markets have been identified in applications such as anti-corrosion equipment, microwave repeaters, and navigational and warning equipment, the projected growth of the market is largely attributed to water pumping and village power applications in the third world. A recent study entitled Export Potential for Photovoltaic Systems conducted by Pacific Northwest Laboratory estimates that water pumping and village power will consitute 39 megawatts of a total estimated foreign market of 53 megawatts by 1986 .

Interest in alternative power sources for agricultural applications can be attributed to a number of factors. The first is the predominant role of agriculture in the economies of most developing countries. Agricultural commodities are usually the main export and are central to the maintenance of a satisfactory balance of the trade. As with the developed countries, the developing countries of the world have found it increasingly difficult to cover the rising costs of petroleum imports.

There is also a realization that the ambitious plans for rural electrification of the last decade will have to be revised sharply downward as grid extension costs continue to rise and urban demand continues to outstrip production capability. Yet the incomes of the

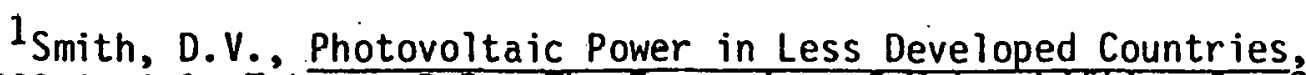
MIT-C00-4094-1; Tabors, R.D., The Economics of Water Lifting for Small Irrigation in the Third World: Traditional and Photovoltaic. Technologies, MIT-EL 79-011; Pacific Northwest Laboratory, Export Potential for Photovoltaic Systems, DOE/CS-0078. 
rural poor--generalily a function of agricultural productivity--must be raised for overall national economic growth to be achieved.

In November 1978 the U.S. Congress passed Public Law 95-590 of which Section lla called for a plan to demonstrate applications of photovoltaic power and facilitate its use in other countries. As one input irito this plan, this paper attempts to assess L.D.C. priorities and goals regarding comercialization within their boundaries. For this purpose the L.D.C. market development process has been divided into three phases: demonstration, early sales, and follow-on sales. In reality, of course, the process is a continuum and most of the conclusions regarding any one phase may be relevant to other phases as well.

The report also includes three case studies at the end. The purpose of their inclusion is to illustrate the larger environment within which policy decisions regarding photovoltaics will be made. This can vary widely from one country to the next according to such factors as national development goals, availability of traditional energy sources, and level of affluence.

Finally, much of the response which has been included in the section on demonstration projects is in reality more applicable to the research and experimentation programs which precede them. This lack of a distinction is consistent with perceptions within the developing countries.

\subsection{Methodology}

This study was based primarily on information from two source types. The first is the rapidly expanding pool of studies, applications 
assessments, and reviews of the solar programs of other countries, as well as more general Department of Commerce studies of countries' trade and investment policies. Also examined were national development plans and economic studies conducted by international banking institutions.

Second, extensive interviews were conducted with researchers who had traveled to Africa, Asia, and Latin America on behalf of the International Solar Commercialization Working Group (I.S.C.W.G.) and with members and/or hosts of visiting delegations of energy officials from L.D.C.'s. In particular, these fureign delegations consisted of participants in the A.I.D.-sponsored Solar Energy Project, the I.C.A.-sponsored Latin American Seminar on Energy Economics, and the African Solar Energy Workshop, cosponsored by A.I.D., U.N.D.P., and U.N.E.P. Lists of participants in the above are contained in the Appendices for the purpose of forming a basis of institutional and personal contacts within the developing countries.

Last, interviews were conducted with members of the photovoltaics industry, the academic community, officials of the Departments of State, Commerce, and Energy, and the Agency for International Development, as well as numerous nongovernmental organizations.

Two caveats should be stated. Particlpants in Lhe above workshops and seminars, who form the bulk of foreign input into this report come predominantly from technical backgrounds. Input from politicians and development planners from these countries was, unfortunately, less accessible.

Second,--and this applies mainly to the post-demonstration section of the report--attempts to predict the postures of governments on specific energy issues is quite risky. Projections are based on 
extrapolations from past trade policies, current economic trends, and a few commercial transactions in this area to date.

\subsection{Demonstration Programs}

\subsection{Introduction}

The effectiveness of demonstration programs as an implement of technology diffusion is broadly recognized in the field of policy analysis. From the interviews and presentations of the numerous participants in the African Solar Energy Project and the Latin American Seminar on Energy Economics, it is strongly apparent that the role of demonstration programs in developing countries is more pivotal yet. In particular, a program must address the requirements of four groups. These are: the technical community, planners, nontechnical government officials, and the general public.

\subsection{Technical Community}

For the technical community--generally those working in universities or government laboratories--demonstration programs fill an important role. Specifically, the following points were made:

- Depending on the extent of industrialization achieved, most developing countries suffer from varying degrees of weakness in their R\&D programs. This is a result both of shortages of trained manpower and in adequate funding. Yet, academic and governmental laboratories fill a critical advisory role in technology-based policy decisions, such as would be the case with a program of photovoltaic-powered irrigation.

- Demonstration programs fill an important function as a conduit for information on the state of the art in rapidly changing solar technology. After trips to U.S. research institutions, a 
number of visitors expressed concern over their own generally insufficient data bases on solar technology and the time lag in information flow from the U.S. to the L.D.C.'s. As a result of this time lag, photovoltaic power is of ten evaluated (and rejected) on the basis of obsolete data regarding cost and reliability.

- Projects should actively seek the input and involvement of local researchers. Cooperation and technology exchange not only create good will--a vital ingredient for successful marketing--but also serve a valuable function in the successful adoption of new technology. As the report, Export Potential for Photovoltaic Systems, points out, it is necessary to differentiate between applications technologies and production technologies; while the latter may be considered proprietary, the former "is inherently suited to international cooperation since the purchaser has a hand in fitting the technology to his spectfic problems whtle the producer ledrns to make a better product."2

- Demonstration projects have the potential to play a significant role in the training of new solar technicans. One African delegate proposed that demonstration projects have closer ties to vocational training centers in order more effectively to promote solar technology diffusion. It was argued that such training programs have been instrumental in China in the widespread adoption of small-scale biogas plants.

2Pacific Northwest Laboratory, Export Potential for Photovoltaic Systems, U.S.D.0.E. Office for Conservation and Solar Applications DOE/CS-0078, Aprii 1979, p. 6.16 


\subsection{Planners}

Of considerable concern to planners is the social impact of the introduction of new technology. Since at this time irrigation with photovoltaic-powered pumps is cost-effective only for the smallest plots (under two hectares), major questions remain as to the effect on income distribution. Evaluation of social impact will likely not only be required by national governments but also by the aid agencies who will doubtless be called upon to fund any major purchases. Research in this area, preferably conducted by indigenous scientists, should also be designed into any program.

\subsection{Government Officials}

Nontechnical government officials also play a vital role in the adoption of a new technology. Charged with fulfilling national priorities such as increasing agricultural output, reducing rural poverty, or possibly planning rural electrification, they are the group which must ultimately make the decision whether to invest in photovoltaics. Consequently, they must see photovoltaic power demonstrated within the context of its most realistic, cost-effective applications to these problems.

Visibility of projects is a strong necessity. Plans to cultivate actively the interest of government officials should be included in any program. Their success or failure will subsequently be reflected in development $\mathrm{plans}$ and budget allocations.

Finally, some funding agencies like U.N.D.P. do not initiate development programs on their own but rather respond only to government proposals. This further emphasizes the importance of government interest. 


\subsection{Consuming Public}

The fourth group which must be addressed is the public. Given that the primary application for photovoltaics lies with microirrigation, successful diffusion and efficient utilization will largely depend on the confidence and participation of small farmers. In this respect small projects, consistent in scale with local agriculture, may have more impact than large ones. Popular involvement becomes even more crucial if the government seeks to finance the capital costs of purchases from voluntary village cooperatives as has been done in parts of India with other types of investments.

\subsection{General Considerations: Demonstration Programs}

Finally, in addition to the observations and recomendations of the foreign delegates, a number of conclusions of the Department of Commerce study, Analysis of Federally Funded Demonstration Programs, are relevant:

The technology should be well in hand. In the case of photovoltaics, the technologies of interest to L.D.C.'s have been shown to be generally workable and reliable. Although research and development continue, the emphasis lies on production technology and less on applications. Early sales, however, will be less a function of cost than of effectiveness, and a more balanced research program may be required.

- Clcar dislincliuin should be made between experimentation programs, whose purpose is to gather information and develop hardware, and demonstration programs, aimed to show simple and reliable operation. In demonstration programs, hardware should be free of nonessential monitoring equipment, which is frequently indistinguishable to the lay eye from the 
demonstration equipment. Also, initial visibility of demonstration projects should be low to allow for "debugging."

- Large projects should not be emphasized at the expense of small ones. For photovoltaics, which are likely to be cost-effective first in small-scale applications, this may imply a strategy of numerous demonstration projects consisting not of complete photovoltaic villages but perhaps groups of microirrigation pumps allowing multicropping in contrast to surrounding rain-fed fields. The number of pumps should be large enough to support the maintenance and supply infrastructure within a given geographic area.

- To maximize effectiveness, projects should include in planning and operations all elements needed for comercialization. This would apply to manufacturers of pumps, batteries, power conditioning equipment, milling equipment, etc. These firms would gain valuable experience working and marketing abroad and their products would become familiar. Wherever possible, it is also important to identify and cultivate the interest of local institutions which could assist in tcchnology diffusion.

\subsection{Early Sales}

\subsection{Introduction}

Where demonstration projects serve to promote awareness and interest in photovoltaics, early sales will represent efforts to assess independently the value of the technology in meeting developmental priorities. In many ways, this period will act as a more intensive continuation of the demonstration phase. Actual increases in 
agricultural output will be measured, social impact more reliably determined, and political benefits carefully weighed.

\subsection{Role of Systems Availability}

As the study, Export Potential for Photovoltaic Systems, notes, price competition in early sales is probably less important than providing systems which are "easy to buy;" that is, complete systems not requiring indefinite amounts of additional equipment and engineering nor complex negotiations. Technical competition will be on the basis of ability to meet local needs and this will be largely determined by the strength of the engineering effort expended on the demonstration phase. The degree of supplier-client cooperation will be a major factor in determining the success of this effort.

Interviews with visiting scientists confirm this emphasis on the system as opposed to the power source alone. There is an awareness that while photovoltaic-cell modules currently represent $50-80 \%$ of the total system price, this is projected to fall to $20-30 \%$ by 1986 . Together, these facts suggest that the U.S. prograns industry should utilize a "systems house" approach to market' development.

\subsection{Infrastucture Requirements}

Also required for successful sales is the existence of a visible sales and service infrastructure. America being a nation of reluctant exporters, this tends to be a weak area which is by nu mearls reilricled to the fledgling photovoltaics industry. However, it contributes to a lack of familiarity with American brands and trademarks and consequently a general concern about the reliability of the firms themselves.

There are some exceptions to this weakness of an overseas American comercial presence. American manufacturers, for example, tend to be 
both familiar and respected in the fields of agricultural machinery and power-generating equipment--neither completely incompatible with photovoltaics. An effective U.S. marketing strategy could be to involve manufacturers from these areas in the photovoltaics commercialization process, possibly acting as the systems houses. This would address two major L.D.C. concerns, i.e. lack of infrastructure and poor familiarity with manufacturers.

There is a second mechanism for building infrastructure which would involve working with nationals of the consuming country. This can be done either through the utilization of an indigenous firm as distributor or through formation of a joint venture with nationals. Indigenous participation is heavily preferred within the developing countries because it helps build a national comercial base. After touring numerous countries in Africa, southern Asia, and the Middle East, members of the U.S.D.0.E. International Solar Comercialization Working Group concluded that joint ventures provide the most promising mechanism for penetration of the developing country market. This was attributed to strongly nationalist sentiments in favor of self-sufficiency.

\subsection{Summary}

The research conducted for this report confirms a preference in the developing countries to do business with firms making use of indigenous businesses. This not only promotes development but is also politically preferable. In some countries, local agents can be essential to doing business and are used in establishing contacts with government officials, obtaining tenders, and handling details related to completing transactions. 


\subsection{Follow-On Sales}

\subsection{Introduction}

Among the developing countries, particularly the least developed, it is generally accepted that early purchases will involve finished products. This is attributable to the fact that these purchases will still be largely experimental in nature.

\subsection{Indigenous Participation}

At such time as major investment in photovoltaic-powered equipment is deemed desirable, a major criterion in the choice of supplier will be the degree to which indigenous firms participate in the manufacturing process. This point was heavily stressed by visiting scientists and officials and was confirmed by the experiences of U.S. manufacturers. It stems from a number of concerns:

- For the OPEC-dependent developing countries, skyrocketing petroleum costs have posed a serious threat to foreign exchange positions. In most cases, development plans and projected growth rates have had to be revised substantially downward. As a consequence, proposed energy sources are closely examined for their effect on balance of trade. In the case of photovoltaics, this means importing only as much of the products as cannot be produced locally. Initially this will apply primarily to assembly but in time could affect all processes.

- Unemployment is an increasingly serious problem in the third world and will continue to be so well into the future. In Mexico, for example, the size of the labor force will double in the next twenty years. For this reason, planners are 
particularly interested in indigenous labor-intensive processes of production.

- Given the high cost of labor in the industrialized West, there is the potential for significant savings to the consuming countries if inexpensive domestic labor can be utilized. As system cost becomes a more significant factor in purchase negotiations, it is entirely possible that manufacturers will independently elect to manufacture within the consuming country in order to minimize their costs.

- There is a strong desire in numerous countries to build a base of indigenously-owned small and medium scale industry. The goal is not only to increase employment but also to invest. national funds where it is felt there are the highest productivity gains per dollar of capital investment. Consequently, nations like India are especially reluctant to import goods whose manufacture is felt to be consistent with such industries. Also, the technology transfer involved is seen as highly desirable.

- A recurrent theme is the belief that local input into design and production is necessary to minimize cost and optimally take into account local conditions and requirements. These issues are central to the subject of appropriate technology and are fundamental to the diffusion of new technologies.

\subsection{Options for In-Country Involvement}

To meet the consuming countries' requirements for indigenous participation several options are available. These are: utilization of a local firm as a sales and service representative, which could be a 
joint venture to manufacture; a licensing arrangement which could involve the supply of certain components; and use of free-trade zones in which to manufacture.

The extent to which a country requires participation and the mechanism most desirable differ from one country to the next. This study did not attempt to analyze this on a country-by-country basis. However, a number of factors can be identified which affect the policies of a country regarding imports. These would include ideology, the existence of an entrepreneurial class, and the strength of national industry and the political power it wields.

Also pivotal is the extent to which the consuming nation is dependent on outside financing for photovoltaic purchases. If the supplier is able to include long-term financing as part of the package it can exercise more control over the manufacturing process. Conversely, a country like Mexico which can look forward to a more financially secure future, can affort to negotiate strongly for local participation.

Several mechanisms are cmployed to promote indigenous involvement including the licensing of all imports and the assignment of import quotas. Restrictive import tariffs are another common means. Policies regarding direct investment cover the full spectrum from Brazil, which, as part of its ambitious import substitution program requires $90 \%$ indigenous particiation, to Ivory Coast, which has no limit on the degr'e of foreign participation in investment enterprises and encourages foreign investment.

\subsection{Summary}

In virtually every case, the policies of countries regarding photovoltaics have yet to be determined; the process of commercialization 
is only now beginning to mature to the point where policy decisions will be necessary. Extrapolation from past or current policies is limited in value due to the newly acquired priority for energy projects. In the following sections, however, the economic climates of three countries, India, Mexico, and Nigeria, are examined to illustrate some of the factors which will affect such policy decisions in the coming years.

\subsection{Summary and Conclusions}

It is the conclusion of this study that, whether examined in view of competing nations or of competing companies, a major factor in market share determination will be the ability and willingness to engage the developing countries as partners in the comercialization process. Specifically, the following points are made:

- Information flow must be accelerated. It should work in both directions, with research results goint to the developing countries and applications development results coming from them.

- Demonstration programs should be carefully planned to address the requirements of technical workers, planners, government officials, and the public of the hosting country.

- The nature of projects, whether experimentation or demonstration, should be clear to visitors. Demonstration programs should show equipment which is reliable and cost-effective and resist temptation to achieve the dramatic at the expense of the pragmatic.

- Photovoltaics are being evaluated and will be purchased within the context of total systems, such as pumping sets, educational Lefevision systems, etc. Fallure to market accordingly will jeopardize early sales prospects. 
- Firms will need a visible marḱeting infrastructure to satisfy concerns about reliability. It is strongly preferred that such infrastructure include indigenous companies or joint ventures.

\subsection{Country Profile: India}

\subsection{General}

With agriculture contributing approximately $45 \%$ of the GNP, the Indian economy is linked inextricably to weather conditions. Several years of good monsoon rains in combination with increased irrigation, use of fertilizers, and a general increase in gross cropped area have improved output but gains have been largely offset by population growth.

With a per capita GNP of around $\$ 150$, India ranks around the poorest of nations. Imports of approximately 17 million tons of crude oil per year have contributed to a trade deficit averaging $\$ 100$ million a month.

Due to the wide dispersement of rural villages and the low level of rural electrical demand, the government has shown increasing interest in solar alternatives to grid extension. India has good insoluation with an annual average intensity of $550 \mathrm{cal} / \mathrm{cm}^{2} /$ day. In arid and semiarid regions the intensity is as high as $650 \mathrm{cal} / \mathrm{cm}^{2} / \mathrm{day}$.

\subsection{Activity in Solar}

The Indian government has established within its Ministry of Science and Technology an "Expert Panel of Solar Energy." Its function is to advise the government on means to incorporate solar energy into the country's, long-term energy plans.

Considerable funds are being expended on R\&D efforts in numerous areas, with emphasis on biogas and photovoltaics. Other programs include development of low-grade thermal devices for space and water heating, 
crop drying, solar pumps, and water desalination.

7.3 Policies Affecting Photovoltaics Commercialization

Indian economic policy reflects the high priority attached to agriculture. Recognizing that irrigation, along with increased fertilizer usage and introduction of high-yield crops, hold the key to increase and stability of production, the government has steadily raised expenditures in these areas.

As part of its efforts to develop rural areas, it has been the policy to extend the electric grid as rapidly as possible. The percentage of villages receiving electricity from the grid has increased from $0.5 \%$ in 1951 to just over $38 \%$ in 1978 . The number of pumpsets electrified has risen over the same period from 21,000 to over 3.3 million; that is at an annual average rate of $21 \%$.

As a consequence of rising petroleum costs and the great expenses incurred in electric grid extension, the government began to show interest in solar power several years ago. The development of photovoltaic power, however, has been impeded by other government priorities regarding the building of an indigenous manufacturing base.

Policies regarding foreign investment, licensing agreements, and royalties reflect the government's long-range goal of reducing foreign influence in India's industrial and comercial sectors by becoming self-sufficient in modern industrial technology. Any agreements between foreign and Indian businessmen involving the transfer of technology must be evaluated individually by the Directorate General of Technical Development. Major consideration is given to the requirements for imported components and raw materials, the level of technology involved, and the time requircd for the Indian firms to become self-sufficient. 
The Foreign Exchange Regulation Act (FERA) of 1973, as modified in 1976, is the most important piece of legislation affecting foreign investment. It controls the percentage of equity which must be held by indigenous interests according to guidelines based on the priority of the products produced. It is currently uncertain how photovoltaics will be regarded in this area.

The government did express interest in having a foreign manufacturer of photovoltaics build production far.ilities in India and requested proposals. The terms suggested by the government, however, were not considered favorable enough to warrant serious consideration by most manufacturers. Currently, one American firm is negotiating to manufacture photovoltaic-powered microirrigation systems in India using imported cells but details are not available.

It should be noted that recent political events in India could affect government policies bearing on foreign trade'and investment.

\subsection{Country Profile: Nigeria}

\subsection{General}

Nigeria is the eighth largest oil exporter in the world. It flares natural gas and has abundant coal and hydropower reserves. Consequently, interest in solar energy to date has been relatively low. In spite of the country's relative wealth of encrgy sources, huwever, clcctric power is maldistributed; Lagos, with about 4 percent of the population, consumes more than 60 percent of the power.

Of the population of $80-100$ million, approximately 70 percent consists of subsistence level farmers. Of these, 95 percent work small farms of 2 hectares or less. 
While as recently as the early 1970's Nigeria had been a net exporter of agricultural commodities, estimates for 1977 indicate a negative external agricultural trade balance of nearly $\$ 600$ million with total imports of agricultural commodities reaching $\$ 1.2$ billion. This has raised improvement of agriculture to a top priority and generated interest in solar technologies, particular in the areas of irrigation and crop drying.

\subsection{Activity in Solar}

In June 1978 the Ministry of Finance and Economic Development commissioned a study to examine Nigeria's current situation and future prospects regarding energy. Solar energy will be one of the areas to be considered. In addition, the National Science and Technology Development Agency was established in 1977 to supervise energy research, including solar. Solar research at Nigerian universities, however, has remained low and there are not believed to be any commercial solar enterprises. 8.3 Policies Affecting Photovoltaics Comercialization

Agriculture, once the backbone of the Nigerian economy, now contributes less than 25 percent of the GDP and has shown a recent growth rate of 1 to 2 percent in real terms---significantly less than population. 1 major factor contributing to low output has been drought and uneven rainfall distribution.

The government has instituted two major programs to try to reverse this trend, the National Accelerated Food Production Program (1974) and Operation Feed the Nation (1976). These programs have attempted to introduce modern crops and farming techniques and equipment. As a result, Nigeria has proved a rich market for agricultural equipment (the most marketable use for photovoltaics) arid the U.S. alone exported approximately. $\$ 40$ million worth in 1977. Many items considered essential 
for economic development or imported by and for government use are admitted duty free, although it is unknown whether photovoltaics equipment would fall into this category.

In 1974 the Nigerian Enterprises Promotion (Indigenization) Decree went into effect and expresses the policies of the government to increase Nigerian participation in all aspects of economic activity. Consequently, the government prefers to deal through indigenous agents or possibly directly but not through third-country middlemenl.

Established, technically qualified, indigenous distributors do exist in Nigeria although their services tend to be in very high demand and they may even represent the product lines of competing manufacturers. When selling to the Nigerian government, procedural complexities and short lead times make local representation of foreign firms highly necessary.

Along with the Nigerian Enterprises Promotion Decree of 1972 (as amended in 1976 and 1977) the Companies Decree of 1968 controls foreign investment. Business enterprises fall into one of three schedules which determine whether it is (1) exclusively reserved for Nigerians, (2) an enterprise in which Nigerians must have at least 60 percent interest, or (3) an enterprise in which Nigerians need have only a 40 percent interest. It would appear that photovoltaics ventures fall into the third categnry. In addition, limitatiuns cxist on repatriation of earnings and expatriate utilization.

Nigeria suffers from an acute shortage of technically trained personnel and looks highly favorably on investment proposals which include measures to train nationals and are in keeping with its long-range development goals. 
In spite of Nigeria's relatively strong position regarding electrical generation potential the rapid increase in urban demand has delayed rural electrification and this could be a further boost to photovoltaics programs for Nigeria.

\subsection{Country Profile: Mexico}

\subsection{General}

Interest in solar energy has been very high; Mexico is currently the fifth highest user of solar technology in the world. In spite of the recent discovery of substantial petroleum resources, the government is very interested in further developing solar and other alternatives to fossil energy.

Thirty-two percent of the population (over 15 million people) in rural areas have no access to electricity. To address this area, the National Plan for Rural Electrification (1979-1982) calls for the investment of $\$ 420$ million to extend the electric grid. However, the fact that over 80,000 communities having 500 or fewer inhabitants lie in areas of high insolation makes solar power an attractive alternative.

\subsection{Activity in Solar}

There has been considerable activity in both public/academic sectors as well as in private sectors. A major recent development is a $\$ 28$ million joint program with Germany to create a solar.fishing village in Baja California, of which over half of the cost is being paid by the Germans. Current projects involve photovoltaic-powered railroad signals and irrigation pumps, and solar desalination. The government is also believed to be considering a joint program with French SOFRETES for the installation of $10,000 \mathrm{KW}$ solar pumps and several 50KW pumps. Initially 
only the pumps would be assembled in Mexico; later, all components would be fabricated in-country.

\subsection{Policies Affecting Photovoltaics Commercialization}

A top priority for Mexico is a drastic reduction in the level of unemployment. This will continue to remain the case for many years as $46 \%$ of Mexico's population is currently age 14 or younger. In keeping with this, the government has followed an import substitution policy where in it purchases domestic products whenever possible. Foreign purchases are made only when the products are not produced in Mexico or when large price differentials exist.

In the past, imports have been controlled through the use of licensing and import quotas. Products seen to be a threat to domestic firms or generally labor-intensive have been strictly limited or excluded altogether. More leniency has been shown in the import of capital equipment and needed technology.

Mexico is currently changing its policies away from the system of licensing and quotas toward a system of tariffs and no quotas. This should simplify the process of importing into Mexico and, indeed, it is the policy of the government to increase imports as new oil revenues improve the country's foreign exchange position.

In the area of direct foreign investment Mexico has taken a conservative position and solicits or permits forrign investment only when it meets certain criteria. Investment is viewed most favorably when it brings technology not otherwise available, produces locally goods which were otherwise imported, increases the country's exports, or when it provides substantial new employment. The "Law to Promote Mexican Investment and Regulate Foreign Investment, " effective May 1973, governs 
new foreign direct investment and, for example, stipulates that foreign equity investments will not exceed 49 percent of a firm's total equity (there are exceptions to this percentage in both directions).

Considerable financial incentives are available to firms which are majority Mexican-owned including subsidized credit and numerous tax incentives.

Mexico has no foreign exchange controls; capital; profits, and dividends may be readily transferred to and from Mexico.

Free-trade zones cover all of Baja California, the immediately adjacent area of Northwest Sonora, and Quintana Roo. Specified goods may be shipped to these free zones without payment of duty and are generally exempt from the import license requirement. Lists of products eligible for duty-free and/or license-exempt entry into the free zones are subject to change without notice and exporters should check the status of the product prior to shipment to avoid penalties or costly return charges. 
THIS PAGE

WAS INTENTIONALLY

LEFT BLANK 


\section{AFRICAN SOLAR ENERGY WORKSHOP}

May 23-25, 1979

At lanta, Georgia 
Gambia

Benin

Just in Gnidehou

Directeur de la

Planification d'Etat

B.P. 239

Cotonou, Benin

Emile Paraiso

Directeur General de la Societe Beninoise de l'Electricite et d'Eau Cotonou, Benin

Botswana

Phillip Mauco

Rual Uevelopment Unit

Ministry of Finance and Development

Private Bay 008

Gaborone, Botswana

Frank Taylor

Director, PELEGANO

$V i l l a g e$ Industries Program

P.0. Box 464

Gaborone, Botswana

Arriuld de Beer

Village Industries Program

P.0. Box 464

Caporone, Bultswan!la

Cape Verde

Horacio Soares

Director General

Conservation and Development of Natural Resources

Ministry of Rural Development

Cape Verde

\section{Ethiopia}

Ghebru Wolderhiorgh is

Executive Secretary

Ethiopian National Energy Commission

P.0. Box 486

Addis-Abada, Ethiopia
L.0. Jobe

Irrigation Engineer

Hydrometeorological Services

Banjul, Gambia

Ghana

Kwamina B. Dickson

Professor and Head

Department of Geography

University of Ghana

Legon, Ghana

K.0. Kessey

Professor and Head

Department of Mechanical

Engineering

University of Science and

Engineering

Kumasi, Ghana

Guinea

Mohamed Lamine Kaba

Doyen de la

Faculte d'Electrotechnique

I.P.G.A.N.

Conakry, Guinea

Abdul Karim Diallo

Ministere Industrie a Energie Conakry, Guinea

Kenya

Aleke. Uondo

National Council for Science and Technology

Box 30623

Nairobi, Kenya

F.N. Onyango

Department of Physics

University of Nairobi

Nairobi, Kenya

Mali

Ibrahima Toure

Chief, Department du Physique de de la Chimie

Ecole Normale Superieure

Bamako, Mali 
Traore Cheickne

Directeur

Laboratoire Energie Solaire

B.P. 134

Bamako, Mali

Mauritania

Moulaye Abdallah

Directeur Hydraulique et Energie

B.P. 356

Nonakchott, Mauritania

Mustapha Kane

Ingenieur de SONELEC

B.P. 355

Nonakchott, Mauritania

Mauritius

Dr. Suresh Hurry

Senior Lecturer

School of Industrial Technology

University of Mauritius

Port Louis, Maur:, us

Morocco

Professor Omar El-Fassi

Faculty of Science

Mohammed V University

Rabat, Morocco

Niger

Dr. Abdou Moumouni

Directeur

Office de l'Energie Solaire

ONERSOL, B.P. 621

Niamey, Niger

Albert. Wright

Charge de Recherce

ONERSOL

Niamey, Niger

Nigeria

V.A. Akinsette
Department of Mechanical
Engineering
University of Lagos
Lagos, Nigeria

Dr. B.A. Ajakaiye

Department of Chemical

Engineering

University of Ife

Ile-Ife, Nigeria.

A. Suleiman

Faculty of Engineering

Ahmadu Bello University

Zaria, Nigeria

Rwanda

Char les Ntakirutinka

C.E.A.E.R.

U.N.R., B.P. 117

Butare, Rwanda

Senegal

Sada Wane

Maitre Assistant

Faculte des Sciences

University de Dakar

Dakar-Fann, Senegal 655

Ibrahima Cisse

Direction de l'Innovation et du Progres Technologique

Secretariat d'Etat a la Recherche Scientifique et Technique

61 Blvd. Pinet Laprade

Kakar, Senegal

כomalia

Mohamed Yussuf Awaleh

Director, Water Resources

Mogadiscin, Snmalia

Ali Hagi Adan

Coordinator, Environmental

Activities, State Planning

Commission

Mogadiscio, Somalia

Sudan

Professor Y. Hamid

Director

Faculty of Engineering

Institute of Solar Energy

Khartoum, Sudan 
Mohamed Elamin Mukhtar

Forest Department

Khartoum, Sudan

Swaziland

Abraham Tsabeze

Box 26

Piggo Peak

Swaziland

Ms. Linda Vilakati

National Team Leader

UNDP

Women in Deve lopment Project

P.0. Box 431

Swaziland

Harry Dlamini

Box 26

Piggo Peak

Swaziland

Tanzania

Dr. Simon Nkonoki

Institute of Development Studies

University of Dar Es Salaam

P.0. Box 35169

Tanzania

Dr. Mark James Mwandosya

Faculty of Engineering

University of Dar Es Salaam

P. .). Bnx 35169

Tanzania

Togo

Gnininvi Messan

Chief, Solar Energy Department

University of Benin

Upper Volta

Dominique Winkoun

Institute of Mathematics

and Physics

Member of Working Group on

Solar Energy

B.P. 7021

Ouagadougou, Upper Volta
Kabore 0. Francois

Direction de l'Hydraulique et de l'Equipement Rural

B.P. 7025

Ouagadougou, Upper Volta

Jacques Lamadieu

Professor

Interstate School for

Rural Engineers (EIER)

B.P. 7023

Ouagadougou, Upper Volta

OTHER PARTICIPANTS

Donald Anderson

Voice of America

(Africa Division)

USICA

Washington, D.C.

Margot Aronson.

Information Collection and Exchange

Peace Corps

806 Connecticut Avenue

Washington, D.C. 20525

Andreas Bachman

c/o SATA

P.0. Box 113

Kathmandy, Nepal

Dr. Charles Berberich

Solar Energy Research Institute

Golden, Colorado 80401

Jim Bever

Institute for Energy Research

State University at Stonybrook

Stonybrook, New York 11790

John Blumgart

USAID (Africa Bureau)

Department of State

Washington, D.C. 20523

Dr. Kofi Bimpong Bota

Department of Chemistry

Atlanta University

At lanta, Georgia 30314 
Ms. L.V. Brattle

Home Economics Department

University of Surrey

Guildford

Surrey, United Kingdom

William Carter

U.S. Department of Energy

Office of International Affairs

1000 Independence Avenue, S.W.

Washington, D.C. 20585

Cecil E. Cook

Inter-Culture Associates

Box 8264

Columbus, Ohio 43201

Miguel Dagraca.

Programme Analysis Office

UNDP

New York, New York 10017

Mrs. Turi Hammer Digernes

Development Research and Action Programme

The Chr. Michelson Institute

Fantoftvegen 38

5036 F antoft-Bergen; Norway

Frank Dobyns

Arca Foundation

100 E. 85th Street

New York, New York 10028

Richard S. Dosik

Wor Id Bank

1818 H Street, N.W.

Washington, D.C. 20433

Everly Driscoll

Science-Writer/Editor

USICA (Press Division)

Washington, D.C.

Dr. Lawrence Ervin

al Dir'iyyah Institute of Geneva, Switzer land

Arlington, Virginia

Dr. Joseph Etua

Department of Sociology

At lanta University

At lanta, Georgia 30314
Dr. David French

USAID (Africa Bureau)

Department of State

Washington, D.C. 20523

Murray Goldberg

Solar Energy Research Institute

1536 Cole Boulevard

Golden, Colorado 80401

Tom Graham

Donovan, Hamester \& Rattier, Inc.

1055 Thomas Jefferson Street, N.W.

Suite 414

Washington, D.C. 20007

Ms. Fran Gulick

c/o OECD Development Directorate

2 Rue Andre Pascal

75775 Paris CEDEX 16 France

Professor Peter Hammond

409 N Street, S.W.

Washington, D.C. 20024

Dr. Gerald Hine

NASA Lewis Research Center

Cleveland, Ohio

Dr. Essam El-Hinnawi

Chairman, Energy Task Force

UNEP

P.0. Box 47074

Nairobi, Kenya

Henry Homeyer

Peace Corps Director (Mali)

Department of State

Washington, D.C. 20520

Jim Howe

Overseas Development Council

Washington, D.C.

Paul Jankura

Peace Corps

806 Connecticut Avenue, N.W.

Wash ington, D.C. 20525

Stephen Klein

Energy Policy Adviser

USAID

Department of State

Washington, D.C. 20523 
Tom Lawand

Director

Brace Research Institute

Box 900

McDonald College

McGill University

Montreal, Canada H9XICO

Derek Lovejoy

UNCNRET

New York, New York 10017

Dr. Harry Lustig

UNESCO

Consultant on Solar Energy

The City College

New York, New York

Francis luzatto

Director, International and Special Assistance

Peace Corps

306 Connecticut Avenue, N.W.

Washington, D.C. 20525

James F. McDivitt

UNESCO

Paris, France

B. McNelis

General Technology Systems

Forge House.

Brentford TW 8

$8 \mathrm{EQ}$

London. United Kingdom

Dr. Ben Ntim

Brace Research Institute

McGill University

Canada

Paul Polak off

Office of African Affairs

ICA

1750 Pennsylvania Avenue, N.W.

Washington, D.C. 20547

C. Anthony Pryor

Rockefeller Foundation

New York, New York
Dr. Priscilla Reining

AAAS

1776 Massachusetts Avenue, N.W.

Washington, D.C. 20036

George Self

USAID

Washington, D.C. 20523

Dr. Walter Shearer

United Nations University (UNU)

Tokyo, Japan

Professor Andy Sofranko

Department of Agricultural Economics

University of Illinois

Urbana, Illinois 61801

Dr. Carl Spight

Department of Physics

Morehouse College

Atlanta, Georgia

C. Spooner

USAID (Abidjan)

Washington, D.C. 20520

Cost is Stambolis

Heliotechnic Associates

International

5. Dryden Street

London, W.C.2, United Kingdom

Dr. John W. Tatom

4074 Ridge Road

At7anta, Georgia 30080

To Van Tong

UNDP ( Africa Bureau)

One United Plaza

New York, New York 10017

Ranvir K. Trehan

MITRE Corporation

1820 Dolley Madison Boulevard

McLean, Virginta 22102

Ken Ude

Arco-Solar

20554 Plummer Street.

Chatsworth, California 91311 


\author{
J.D. Walton \\ Engineering Experiment Station \\ Georgia Institute of Technology \\ Atlanta, Georgia 30332 \\ Dr. Mamadou Watt \\ PRC Energy Analysis Company \\ 7600 01d Springhouse Road \\ McLean, Virginia 22101 \\ Dr. Jay We instein \\ Department of Social Sciences \\ Georgia Institute of Technology \\ Atlanta, Georgia 30332 \\ Dr. Ernest Wilson, III \\ Department of Political Science \\ University of Pennsylvania \\ Philadelphia, Pennsylvania. 19104 \\ Fred Zobrist \\ USAID \\ Department of State \\ Washington, D.C. 20523
}




\section{THIS PAGE}

\section{WAS INTENTIONALLY \\ LEFT BLANK}


A.I.D. SOLAR ENERGY PROJECT

May 20-June 2, 1979 
Jose Chacon

Solar Program

School of Electrical Engineering

Universidad de Costa Rica

San Pedro Montes de $\mathrm{OCa}$

San Jose, Costa Rica

Centro America

Denis Ridley

Jamaica Public Service Co., Ltd.

6 Knutsford Blvd.

Kingston 10, Jamaica

A.S.M. Nuruzzaman

Institute of Fuel Research and Development

Bangladesh Counc1l of Seientific and Industrial Research

Dacca, Bangladesh

Ali Beba

Department of Chemical Engineering

Faculty of Chemistry

Ege University

Bornova-Izmir, Turkey

Sidonio F.B. Paes

Director-General de Energia:

$R$. da Veneficencia, 241

1300 Lisboa, Portugal

Ishmael W. Lashley

Caribbean Alternative Energy Prograntime

c/o Barbados National Standards Institution

Culloden Road

St. Michael, Barbados

Wert Indies

Gyani R. Shakya

Senior Englneer

B.Y.S. Sanitary Eng., Ltd.

5/755 Jhocche Tole

Kathrnandy, Nepal

Andres Trepp

Instituto de Investigaciones

Fisicas, UMSA

Casilla 1923

La Paz, Bolivia
B.P. Sepalage

Engineer in Charge - Energy Unit

Ceylon Electricity Board

P.0. Box 540

Colombo 2, Sri Lanka

Jean-Guy Rigaud

Department des Mines et des Resources Energetiques

Boite Postale 2174

Port-au-Prince, Haiti

West Indies

Tae S. Yim

Director

Solar Energy Research Institute

P.0. Box 131

Dong Dae Mun

Seou 1, K.orea

Norberto Quezada

Instituto Superior de Agricultura

Apartado \#166

Santiago, Dominican Republic

Sergio Varas

Casilla 677

Santiago, Chile

I acovos Papadopoulos

Ministry of Commerce \& Industry

Nicosia, Cyprus

Malek A. Kabariti

Royal Srientific Society

M.E. Department

P.0. Box 5211

Amman, Jordan

Ernesto N. Terrado

Bureau of Eneryy Development

Ft. Bonifacio, Metro Manila

Phillipines

Ricardo A. Garcia

Central American Research

Institute for Industry

(ICAITI)

Av. de la Reforma 4-47

Zona 10, P.0. Box 1552

Guatemala City, Guatemala 
Sofjan H. Nasution

B.P.P.T.

Thann in 8

Jakarta, Indonesia

Marco A. Zuniga

Professor of Physics

Director of Appropriate Technology Program

University (National Autonomous) of Honduras

Tegucigalpa D.C., Honduras

Alfredo Overos $D$.

Jefe Programa de Energias Naturales No-Convencionales ITINTEC

Esq. Jr. Morelli y Av. Las Artes

Ur. San Borja

Lima, Peru

Mohammad Chafke

Ministry of Electricity

Technical Adviser to the Minister

Barada Street

Damascus, Syria

Ali Mounzer

National Council for Scientific Research

P.0. Box 8281

Beirut, Lebanon

Charuay Boonyubol

Faculty of Engineering

Chulalongkorn University

Bangkok, Thailand

Mohammed Sennoune

Ministry of Energy and Mines

Rabat, Morrocco

Ibrahim Sakr

National Research Centre

Dokki, Cairo, Egypt

Rogeria P. Kluppel

Coordinator

Solar Energy Programs

SETEC/MME

Ministeria de Minas e Energia

Esplanada dos Ministerios

Brasilia, Brazil
Dr. R.L. Datta

c/o Asiatic 0xygen, Ltd.

First Pokhran Road

Thana (Bombay)

India

Dr. Ing. Ghebru Woldeghiore is

Executive Secretary

Ethiopian National Energy

Commission (ENEC)

P.0. Box 486

Addis-Ababa, Ethiopia

Or. Suresh Hurry

Head, Electrical Engineering

Division

school of Industrial Technology

University of Mauritius

Reduit, Mauritius

K.0. Kessey

University of Science and Technology

Kumasi, Ghana

Dr. Mark Mwandosya

University of Dar-es-Salaam

P.0. Box 35131

Dar-es-Salaam, Tanzania 


\section{THIS PAGE WAS INTENTIONALLY LEFT BLANK}


LATIN AMERICAN SEMINAR ON ENERGY ECONOMICS July 8 - August 4, 1979 
Captain Luis E. Benitez

Vice President

Uruguayan Power Company,

Montevideo, Uruguay

Mr. Eric Casamizuela

Deputy Director

Lempa River Hydroelectric Commission (CEL)

San Salvador, El Salvador

Mr. Renan Castaneda

Head, Financial

Programming Division

Ecuadorean Electrification Institute (INECEL),

Quito, Ecuador

Mr. Allan A. Challeill

Manager of Freezone and Industrial Parks

Office of Industry and Development

Curacao, Netherlands Antilles

Mr. Manuel Guevara Baro

Acting Chief

Department of Energy Outlook Studies,

Division of Energy Planning

Ministry of Energy and Mines

Caracas, Venezuela

Mr. Pạblo Jaramillo Barriga

Head ur Fr.onomic Studics

National Flectricity

Company (ENDESA)

Santiago, Chile

Mr. Roger Levy

Director General,

National Electrification office

Ministry of Energy, drid Hydrocarbons

La Paz, Bolivia

Dr. Fernandn Victor Vinelli

General. Manager

National Gas Company

Buenos Aires, Argentina

Mr. Luis Felipe Molina Torres

Ministry of Economy Representative on National Energy Commission

Tegucigalpa, Hoduras
Mr. Eugenio 0eio Gonzalez

Assistant Director for P.lanning

Costa Rican Institute for

Electricity (INE)

San Jose, Costa Rica

Mr. Enrique Rodrigues Vargas

Director, Planning Office

Ministry of. Mines and Energy

Bogota, Colombia

Mr. Jean Claude Souriac

Director of Planning

Electricity Company of Haiti,

Port-au-Prince, Haiti

Mr. Alberto Tamer

Petroleum Economics Editor

o Estäin de Sau Paulo

Soo Paulo, Brazil

Mr. Carlos Enrique Mancilla Mejia

Deputy Chief

Department of Economic and

Financial Planning

National Institute of

Electricity (INDE)

Guatemala City, Guatemala

Mr. Ewart Scott

Energy Economist

Ministry of Mining and Natural Resources

Kingston, Jamaica

Mr. Luis Haro

Engineer

Sectoral Planning Office

Ministry of Energy and Mines

Lima, Peru 
H. 4 TRANSNATIONAL ISSUES OF THE

INTERNATIONAL PHOTOVOLTAIC PLAN

Lewis J. Perelman

and

Sylvia H. Forman

Jet Propulsion Laboratory

September 1979 


\section{THIS PAGE WAS INTENTIONALLY LEFT BLANK}




\section{INTRODUCTION}

This is the final report of the Transnational Issues Study carried out by JPL in support of SERI and DOE for the development of the International Photovoltaics Program Plan (IPPP) mandated by the Photovoltaics Research, Development, and Demonstration. Act of 1978. The authors wish to express their appreciation for the contributions of the many individuals who agreed to be interviewed for this task, and also for the assistance provided by the staff of the Solar Energy Research Institute, the Massachusetts Institute of Technology Energy Laboratory, and the Rockefeller Foundation.

This task was conducted by Dr. Lewis Perelman with the assistance of Dr. Sylvia Forman, JPL Summer Faculty Fellow from the Department of Anthropology of the University of Massachusetts. Paul Carpenter of JPL directed the study, and support services were provided by Dr. Richard Tabors of MIT/EL.

Individuals interviewed for the study are listed in Annex A. Attendees of the Rockefeller Foundation meeting and the MIT/EL workshop are listed in Annex B.

\section{METHODOLOGY}

The objective of the transnational issues study was to examine critical issues beyond the domestic and technical concerns relevant to the implementation of the IPPP. Key issues examined in this study included:

- requirements and constraints of foreign governments and international agencies whose cooperation will be required in implementing United States international photovoltaic activities;

- scope and type of interests in photovoltaic development outside the federal government and existing photovoltaic industry;

- potential social, economic, and environmental impaots of United States international photovoltaic activities;

- the general international political environment in which the IPPP must be implemented; and

- optimum approaches to United States international photovoltaic field projects and other overseas photovoltaic program activities.

The approach to the task was based in general on focused interviews, reviews of relevant literature and archival documents, and a workshop with a panel of experts. Specific subtasks included:

A) Interviews of relevant individuals in United States government agencies, international agencies, nongovernmental organizations (NGOs), universities, and private firms;

B) Site visit to Schuchuli Indian Reservation photovoltaic project;

C) Attendance of Conference on Solar Electric Applications for American Indian Communities (Tucson, Arizona, 21-22 June 1979); 
D) Attendance of meeting at the Rockefeller Foundation on the role of private foundations in international solar energy development (New York, 22 June 1979);

E) Workshop at the MIT. Energy Laboratory (MIT/EL) with a panel of experts in the politics and economics of international development assistance (9 July 1979);

F) Review of existing and pending United States bilateral solar energy agreements;

G) Review of 2 existing United States international photovoltaic demonstration projects; and

H) Review of Department of Energy "country notebooks".

GENERAL FINDINGS: PROGRAM STRATEGY

1. Conflict between domest1c photovoltaic development goals and internationa1 political goals is potentially severe.

The general view was that a "blatant industry bias" in the IPPP would provoke resistance and hostility among the less developed countries (LDCs) the program presumably would be directed at. LDCs will be hostile to any United States program which appears self-serving, even though there may be expected mutual benefits. The Department of Energy (DOE) is widely viewed as inexperienced and insensitive in political relations with LDCs (e.g., natural gas negotiations with Mexico). LDCs will be especially skeptical about United States motives in promoting LDC adoption of a technology which is not yet established in domestic use. On the other hand, demonstrated United States commitment to domestic photovoltaic development and applications could enhance acceptance of United States products in competition with other photovoltaic suppliers such as Germany, France, or Japan. In reviewing the hearing record for the Photovoltaic RD\&D Act, we noted that testimony was dominated by domestic industry representatives. Viewpoints surveyed in this study are likely to appear in future Congressional hearings on international photovoltaic development, and indeed will need to be considered if a successful international program is to be achieved.

2. There is considerable uncertainty and skepticism about the existence of a substantial photovoltaic market in LDCs.

Most development experts contacted were highly skeptical about the existence of a substantial market for photovoltaic sales in LDCs. The experts noted that LDCs generally lack the money to buy photovoltaic equipment except for limited aid money and a few currency-earning cash crops. There is an important difference between the potential need for photovoltaic energy in LDCs and the ability to pay for equipment; also, in most LDCs there is an important difference between the potential purchasers and the potential users of photovoltaic systems. Anthony Pryor argued that the inability of poor countries to pay for increasingly costly diesel fuel does not imply a greater ability to pay for photovoltaic systems. Actually, recent Organization of Petroleum Exporting Countries price increases threaten to push many poor countries over the brink of bankruptcy, implying little financing available for future imports of photovoltaic systems. 
While new OPEC prices will increase the annual trade deficits of LDCs by \$12-16 billion, OPEC will increase financial aid to LDCs by only $\$ 100$ million.

Many experts we contacted mentioned the high cost of photovoltaics in explaining current reluctance to use photovoltaicsin development projects and to have the Agency for International Development (AID) subsidize photovoltaic distribution. The Peace Corps felt even more strongly about the cost issue than did AID and the Institute for Scientific and Technological Cooperation (ISTC). Individuals within all these agencies expressed concern (ranging from mild to serious) about the "high technology" image of photovoltaics and about the "appropriateness" of photovoltaics for the development process.

People we interviewed noted that $65 \%$ to $90 \%$ of energy used in rural areas of LDCs is used for cooking. The growing demand for cooking fuel has led to serious deforestation problems and to extensive displacement of biomass materials from agricultural uses to cooking. Therefore, finding replacements for cooking fuels is a high priority concern to development assistance agencies; interest in photovoltaic applications is relatively less urgent.

Most of the experts questioned whether there is really a market for photovoltaics in the LDCs. If so, it is likely to exist in the relatively developed areas of the LDCs--in countries such as Mexico, India, and Brazil, and in some urbanizing pockets of other poor countries. Even the few LDCs that are rich in oil or some other exportable resource tend to have little discretionary income or even may be in debt because of the pressures of poverty and population growth. The application of photovoltaics in millions of rural villages was viewed by most of the experts as highly unlikely without massive foreign aid which does not now exist. To the extent that an LDC market for photovoltaics may exist, it is precisely in those countries that will be most committed to local production rather than imports. That is, the export market (if any) will be one for joint ventures, licensed production, turnkey factories, technical services, and some end-use equipment (pumps, TV sets), rather than for large-scale, continuous importation of photovoltaic systems.

3. The strategy of using the international market as a "springboard" or "bridge" Eor developing the domestic photovoltaic industry involves high risk and potential political opposition.

Some experts believe that the purpose of the IPPP is to provide a "springboard" to accelerate the development of the domestic photovoltaic industry until a substantial domestic market is realized. A major obstacle to the "springboard" strategy is that the existence of any LDC market, or of any LDC market for sizable United States exports, is highly uncertain. Therefore, a domestic development strategy which depends on the existence of such a market entails prodigious risk for both the stability of the domestic photovoltaic industry and the success of the domestic photovoltaic development program. Even assuming that such a market does exist, there are the crucial questions whether (I) the size of the total market, and (2) the United States share of the total market would be large enough to sustain several or even a single photovoltaic mass-production line inside the United States. Furthermore, the "springboard" strategy would appear to face strong political opposition from domestic solar lobbyists, from international development interests, and from LDC governments. The domestic solar lobby appears to prefer a separation of domestic from international photovoltaic development, wanting strong federal support for both independently. Development interests view such a strategy as politically and economically counterproductive. And LDCs 
will not see direct benefits to themselves from helping United States industry (of course, industrialized countries with the potential for developing their own photovoltaic production capacity would be even more resistant.)

4. The role of OPEC in the international photovoltaics market could become significant.

Several individuals speculated that OPEC, following recent price increases, may find it politically expedient to commit substantial aid money to the development of renewable energy in LDCs, given the disastrous impact of oil price increases on LDC economies. If so, this could have a major impact on the tangibility of the international photovoltaics market, and on the direction of the IPPP. So far, though, OPEC assistance commitments to the LDCs have been minimal.

5. Mexico could become an important_collaborator in photovoltaic development.

There is some indication that Mexico may be interested in seeking United States assistance with photovoltaic development in that country. Development experts disagreed about the potential of Mexican demand for photovoltaics, given Mexico's abundant supplies of oil and gas. Some felt that Mexico would develop oil and gas for export use and seek to develop labor-intensive, renewable energy sources for domestic use. Others believed the Mexicans would rely primarily on their fossil fuel resources to support industrial development, and would not offer a significant market for photovoltaics.

6. 'lhe IPPP has the potential for greater negative impacts than any previous federal solar program.

A final but sober conclusion is that the IPPP has a serious potential for actually. doing harm to photovoltaic development, the domestic industry, and United States toreign relations. LDC "markets" are, in tact, highly vulnerable social systems where even minor economic, political, or ecological perturbations may have disastrous consequences for the local population. An ominous example particularly germane to the potential application of photovoltaics for water pumping in LDCs is the case of the African Sahel. In this region, Western development assistance emphasized introduction of deep water wells, designed to encourage the proliferation of nomads' herds. However, the ultimate results were overgrazing, increased desertification, and widespread starvation:

By the late 1960s desertification had set in, and with no end of the drought in sight, a major international effort was required to keep m1111ons of Sahelians allve.... It is reasonable that climate varlations were not solely responsible for the disaster. Clearly, thoughtless applications of technology and poorly examined social and economic priorities must also be deeply implicated.*

The margin for error in photovoltaic development programs in LDCs is several orders of magnitude smaller than in domestic technology development programs. Existing federal solar energy programs have not yet had to deal with such vulnerable environments. Ill-conceived and improperly executed photovoltaic projects in LDCs could prove counterproductive to United States foreign policy

* S. Schneider. The Genesis Strategy. New York: Plenum, 1976; pp. 81-83. 
goals and to the development of the photovoltaics industry.

GENERAL FINDINGS: PROGRAM IMPLEMENTATION

1. Interagency coordination needs to be developed and strengthened.

There was universal recognition that the present lack of effective coordination among concerned federal agencies would be a major barrier to any international photovoltaics program. Lincoln Gordon (Resources for the Future) and James Howe (Overseas Development Council) recommended in a recent report the creation of an International Energy Development Service (IEDS), modeled in part after the agricultural and energy extension services. The IEDS would combine staff of DOE and AID. Some such structure clearly would be valuable for an effective IPPP.

Our informal survey suggested considerable strain in the relations between DOE and foreign assistance agencies. Individuals within both DOE and AID felt that links between those two agencies so far had not been satisfactorily effective.

2. There is confusion over the meaning of "demonstration" program.

Many of those contacted felt that a "demonstration" program would be an essential feature of an IPPP. However, there are at least three different types of "demonstration" projects to be considered:

- experiments to further technology development (type I);

- experiments to establish the economic, social, and environmental feasibility of working systems in authentic field conditions (type II); and

- promotional demonstrations to encourage user awareness and acceptance of proven systems (type III).

Development experts argue strongly for the type I and type II approach. The United States-Saudi photovoltaic project is viewed almost universally as an inappropriate model for the kind of demonstration program needed in the IPPP. Also, several development experts noted that recent French and German "demonstration" projects may prove ineffective and even counterproductive; therefore, the United States should not necessarily try to "catch up" with these existing promotional activities.

Photovoltaic systems have to be designed, installed, and managed in such a way that (a) they work well and (b) that they actually and effectively meet local needs. Existing demonstration projects (both of the United States and other nations) generally do not satisfy these criteria. For a successful demonstration program, untested systems must be avoided; demonstration projects must be carefully monitored; and system design (both sizing and balance of systems design) must reflect sensitive understanding of local environmental and social realities. Overseas "demonstration" projects should be tied to domestic technology development through sub-programs specifically aimed at LDC and other export markels. In general, projects should require local financial participation at a level which would simulate ultimate market performance. 


\section{Effective program management is needed.}

Effective IPPP program management requires provision for continuing Congressional oversight, appropriate experimental design and control of projects, thorough evaluation and documentation of project experience, and systematic reporting requirements. Assessment and evaluation of social, cultural, political, and environmental impacts of projects is essential.

\section{Relation to United States industry should be carefully managed.}

United States industry participation in development projects is useful but needs to be subordinated to the direction of responsible United States government and foreign government agencies. United States government efforts to facilitate export marketing of domestic photovoltaics is appropriate and necessary, but should be clearly separated from technology and socioeconomic development programs. Export marketing assistance should be only for proven equipment and systems, following adequate tield testing (type I and rype II) experience.

\section{The role of AID is important.}

There was strong feeling among development experts that the IPPP should be directed, at least outslde the United States, by experienced development agency (AID) personnel, knowledgeable about development programs and about the specific countries where projects would be implemented.

Within AID, program linkage is difficult. Most program definition in AID is done by the country missions (though reviewed in Washington). It is difficult, if not impossible, for AID/Washington to initiate programs or projects for the country missions. This seems to indicate that the primary need within AID related to the IPPP would be information flow. The information flow would have to be in two directions. AID/Washington (especially the energy offlce) has lu let the country missions (and the country desk officers in Washington) know about photovoltaic possibilities; on the other hănd, those missiuns Llial du undertake projects with a photovoltaic component have to let Washington staff have timely, ongoing feedback on project operation and impacts. This feedback, in turn, should be directed to DOE and industry. Furthermore, in relation to some aspects of the commercialization of the IPPP, country missions have to be encouraged to promote awareness of and to dissemiliale intormation about demonstration projects.

In AID, the average time between project conception and signing of an agreement for implementation is 2.7 years. Country mission staff stay from 2 to 4 years in a country. Thus, there is a lack of continuity in uverseeing projects from conception through implementation phases; there is a need for continuous information: flow to reach newly arrived personnel in each country; and it takes a long time to get even a small demonstration project launched.

\section{Review two existing projects.}

Two existing projects, managed for AID and DOE by the NASA Lewis Research Center, suggest the implications of the IPPP at the local, project level. One project is in the African nation of Upper Volta while the other is located in a 
Schuchuli Indian village in Arizona. Forman visited the Schuchuli Indian Reservation project and we reviewed information concerning both this and the Upper Volta project. The photovoltaic system at Schuchuli has been in operation since mid-December 1978. It was fully operative when Forman visited in June 1979. So far, there had been one outage of the system, caused by a failure of a control light in the voltage monitoring instruments (in the experimental instrumentation), which in turn caused a disruption of the entire monitor/control instrumentation. Other problems with the system have been primarily with the equipment run by the photovoltaic source: the water pump has broken several times; air compressors for the refrigerators have caused some problems; breakers and fuses require periodic attention. The village headman acts as the routine system monitor; records data for NASA Lewis; handles minor system problems; and cleans the photovoltaic panels periodically. This work requires about. 1 hour a day of his attention when there are no problems. He appears to feel comfortable with the system, to understand his maintenance duties clearly, and to feel confident about carrying out his duties. (The photovoltaic system in Upper Volta is managed in a similar fashion, though monitoring there is apparently simpler, since the instrumentation is simpler.)

From conference reports and brief discussion with the village headman, it appears that villager maintenance is a viable possibility, with a modicum of training provided. The enhanced degree of sense of involvement and control that goes with maintenance by local people is probably more than worth the relatively small cost of training them to conduct it. The more articulate and politically oriented Native Americans who attended the conference mentioned a number of times that one of the attractions solar energy holds for them is independence from the grid and from other outsiders. This would likely be the case in some developing country settings also, and could be considered a notable selling point for photovoltaic systems.

System design for Schuchuli was facilitated by the fact that villagers had diesel generators and prior experience with electric appliances. Thus they were in a position to articulate their own priorities for the load. Also, NASA Lewis was able to estimate reasonably the demand and the sizing.

Apparently the Upper Volta site has had much more trouble than Schuchuli. The photovoltaic panels there were damaged to some extent by animals. The graingrinding mill has not worked well and is going to have to be replaced, after causing dissatisfaction among the villagers. The overall system design for Upper Volta appears to have been less appropriate and less well adapted to the local environment. 
G. William Anderson

Don Bahr

Tudd Dartlemm

William Bitāno

John Blumgart

Jerome "Sam" Bosken

Norman L. Brown

John Davidson

-Henry Eaton

Erik Eckholm
Program Evaluation, Bureau for Program and Policy Coordination, U.S. Agency for International Development

Anthropologist Tucson, Arizona

International Institute for Environment and Development

NASA bewis Research Center

Chief, Selected Development Problems Div., Office for Development Resouroes, Bureau for Afrlca, U.S. Agency for International Development

Deputy Director, Office of Energy, U.S. Agency for International Development

Special Advisor on Energy, and Chicf of Soientific, Technical, and Environimental Proplsleüs, Bureau for Asia, U.S. Agency for International Development

U.S. Council on Environmental Quality

Subcommittee on Energy Development and Applications, Committee on Seience and Teshnology,

U.S. House of Representatives

Worldwatch Institute (now with U.S. Dept. of State) 
Lawrence Ervin

David French

Lincoln Gordon

Peter Hakim

Denis Hayes

Allan Hoffman

Paul Jankura

Robert Jordan

Sean Killeen

Stephen Klein

Derek Lovejoy

Frances Luzzato

Princeton Lyman

Anthony Meyer

Roger D. Moeller al Dir'iyyah Institute

Bureau for Africa, U.S. Agency for International Development

Resources for the Future

Ford Foundation

Worldwatch Institute

(now Director, Solar Energy

Research Institute)

Director,

Advanced Energy Systems Policy

Div.,

Office of Policy and Evaluation,

U.S. Dept. of Energy

Peace Corps

Director of Public Affairs,

Overseas Private Investment Corp.

Center for International Studies, Cornell University

Energy Coordinator, Program and Policy Coordination, U.S. Agency for International Development

Center for Natural Resources, Energy, and Transport,

United Nations

Peace Corps

Planning Commission for the Institute for Scientific and Technological Cooperation, U.S. Dept. of State

Educational Technology office, Development Support Bureau, U.S. Agency for International Development

Office of Science and Technology, U.S. Agency for International

Development 
Richard Munson

Ted Owens

Norma Parker

Edgar N. Pike

Anlliüny Pryor

William Ramsay

Anthony Ratajczak

Louis Rosenblum

James Rowe

George Sel.f

Joan Shorey

Emmy Simmons

Cathy Stoudt

Jim Tarrant

Ishrat Usmani
Solar Lobby

Appropriate Technology

International

Acting Energy Coordinator, Office of Development Resources, Bureau for Latin American and the Caribbean, U.S. Agency for International Development

Science and Technology Div., Bureau for Near East, U.S. Agency for International Development

Rnnkefeller ḱoundation

Resources for the Future

NASA Lewis Research Center

NASA Lewis Research Center

International office, American Association for the Advancement of Science

Technical Support office, Social Analysis Division, Bureau for Near East, U.S. Agency for International Development

Solar Lobby

Office of Program Review in Rural Development, Bureau of Program and rolicy Courdination, U.S. Agency for International Development

Office of Women in Development, U.3. Ageney for International Development

Overseas Development Council

Center fur Natural Resourcco, Energy, and Transport, United Nations 


\section{Participants in Rockefeller Foundation Meeting}

\section{(22 June 1979)}

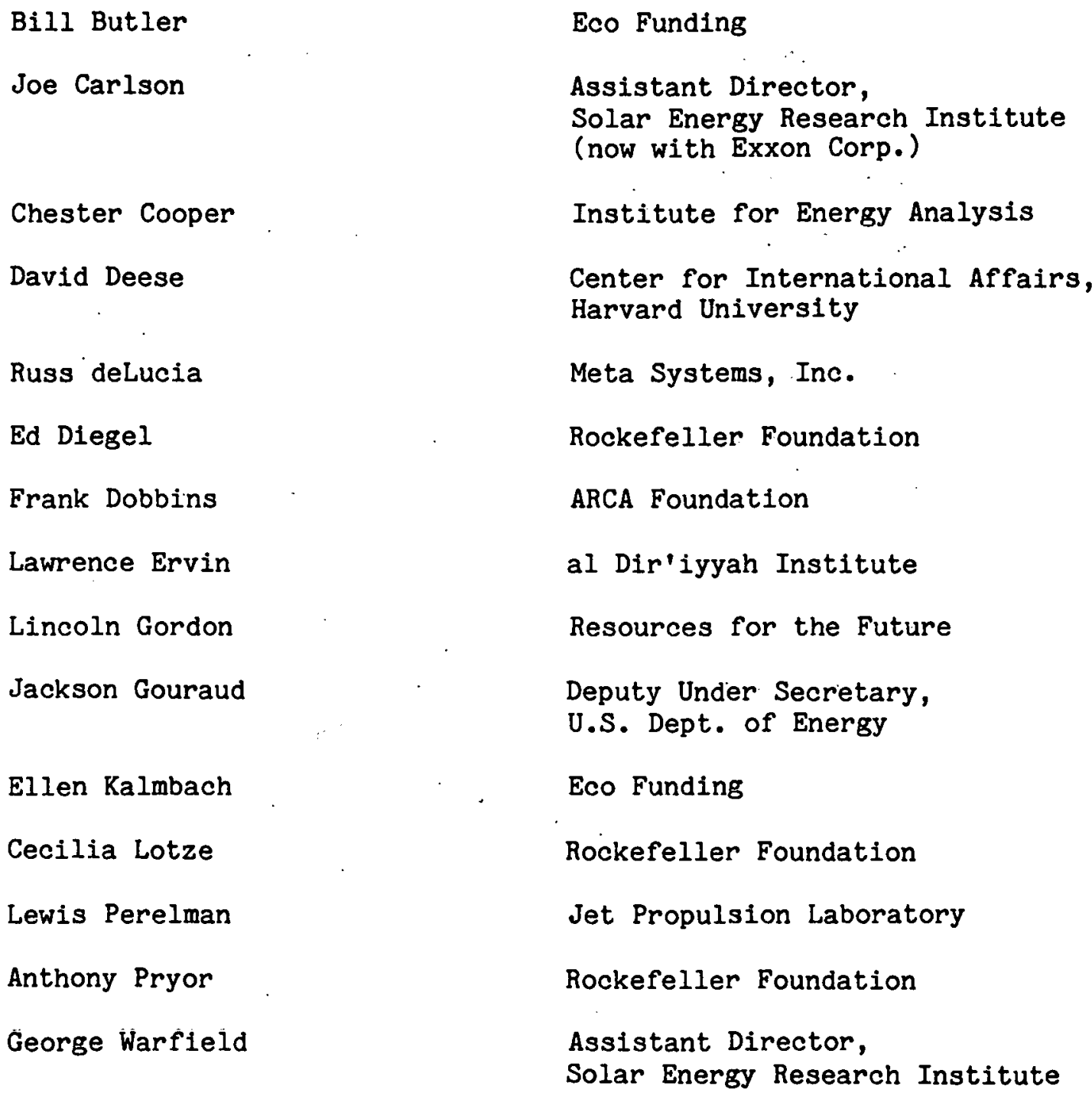




\section{Participants in MIT Workshop}

(9 July 1979)

John Briscoe

Paul Carpenter

Dennis Costello

Russell delucia

Thomas Klein

Thomas Neff

Lewis Perelman

Peter Rogers

Douglas V. Smith

Alan Strout

Richard Tabors
Harvard University

Jet Propulsion Laboratory

Solar Energy Research Institute

Meta Systems, Inc.

MIT

MIT

Jet Propulsion Laboratory

Harvard University

Consultant

Consultant (MIT)

MIT 


\begin{tabular}{|c|c|}
\hline \begin{tabular}{c|c}
$\begin{array}{c}\text { Document Control } \\
\text { Page }\end{array}$ & $\begin{array}{c}\text { 1. SERI Report No. } \\
\text { TR-52-361 }\end{array}$
\end{tabular} & 3. Recipient's Accession No. \\
\hline 4. Title and Subtitle & $\begin{array}{l}\text { 5. Publication Date } \\
\text { October } 1979 \\
\end{array}$ \\
\hline International Photovoltaic Program Plan, Volumes I \& II & 6. \\
\hline $\begin{array}{l}\text { 7. Author(s) Costello, Koontz, Posner, Heiferling, Carpenter, } \\
\text { Forman, Perelman }\end{array}$ & 8. Performing Organization Rept. No., \\
\hline 9. Performing Organization Name and Address & $\begin{array}{l}\text { 10. ProjecUTask/Work Unit No. } \\
\text { Task No. } 5224\end{array}$ \\
\hline $\begin{array}{ll}\text { Solar Energy Research Institute } \\
\text { 1617 Cole Boulevard } & \text { Jet Propulsion Laboratory } \\
\text { Golden, Colorado } 80401 & 4800 \text { Oak Grove Drive } \\
& \text { Pasadena, Calif. } 91103\end{array}$ & $\begin{array}{l}\text { 11. Contract (C) or Grant (G) No. } \\
\text { (C) } \\
\text { (G) }\end{array}$ \\
\hline \multirow[t]{2}{*}{ 12. Sponsoring Organization Name and Address } & $\begin{array}{l}\text { 13. Type of Report \& Period Covered } \\
\text { Technical Report }\end{array}$ \\
\hline & 14. \\
\hline \multicolumn{2}{|l|}{ 15. Supplementary Notes } \\
\hline \multicolumn{2}{|c|}{$\begin{array}{l}\text { 16. Abstract (Limit: } 200 \text { words) } \\
\text { The International Photovoltaics. Program Plan is in direct response to the Solar } \\
\text { Photovoltaic Energy Research, Development, and Demonstration Act of } 1978 \text { (PL 95-590). } \\
\text { As stated in the Act, the primary objective of the plan is to accelerate the } \\
\text { widespread use of photovoltaic systems in international markets. Benefits which } \\
\text { could result from increased international sales by U.S. companies include: } \\
\text { stabilization and expansion of the U.S. photovoltaic industry, preparing the } \\
\text { industry for supplying future domestic needs; contribution to the economic and } \\
\text { social advancement of developing countries; reduced world demand for oil; and } \\
\text { improvements in the U.S. balance of trade. The plan outlines programs for } \\
\text { photovoltaic demonstrations, systems developments, supplier assistance, information } \\
\text { dissemination/purchaser assistance, and an information clearinghouse. Each program } \\
\text { element includes tactical objectives and summaries of approaches. A program } \\
\text { management office will be established to coordinate and manage the program plan. } \\
\text { Although the U.S. Department of Energy (DOE) had the lead responsibility for } \\
\text { preparing and implementing the plan, numerous federal organizations and agencies } \\
\text { (U.S. Departments of Commerce, Justice, State, Treasury; Agancy for International } \\
\text { Development; ACTION; Export/Import Bank; Federal Trade Commission; Small Business } \\
\text { Administration) were involved in the plan's preparation and implementation. }\end{array}$} \\
\hline \multirow{3}{*}{\multicolumn{2}{|c|}{$\begin{array}{l}\text { 17. Document Analysis } \\
\text { a.Descriptors Photovoltaic Cells ; Market ; Budget ; Financial Data ; International } \\
\text { Aspects; Legal Aspects; Legislation ; Environmental Impacts ; Cost Benefit } \\
\text { Analysis; Demonstration Programs; Commercialization } \\
\text { b.ldentifiers/Open-Ended Terms Solar Photovoltaic Energy Research, Development, and } \\
\text { Demonstration Act of } 1978 \text {; International Photovoltaics Program Plan }\end{array}$}} \\
\hline & \\
\hline & \\
\hline \multicolumn{2}{|l|}{$63,63 a, 63 b, 63 c, 63 d, 63 e$} \\
\hline \multirow{2}{*}{$\begin{array}{l}\text { Availability Staiement } \\
\text { NTIS, U. S. Dept. of Commerce } \\
5285 \text { Port Royal Road } \\
\text { Springfieid, VA } 22161\end{array}$} & $\begin{array}{r}\text { 19. No. of Pages } \\
218\end{array}$ \\
\hline & 20. Price $\$ 9.25$ \\
\hline
\end{tabular}

